\title{
Sker der noget med læringsudbyttet, når undervisningssproget skiftes?
}

\author{
Camilla Falk Rønne Nissen, ph.d.-stipendiat, Institut for Nordiske Studier og \\ Sprogvidenskab, Københavns Universitet
}

Lars Ulriksen, professor, Institut for Naturfagenes Didaktik, Københavns Universitet

\section{Videnskabelig artikel (anonym peer-review)}

I takt med en øget internationalisering af de videregående uddannelser øges mængden af undervisning på engelsk på de danske universiteter. Men hvilke konsekvenser har det for kvaliteten af undervisningen? Falder læringsudbyttet, når der undervises på et sprog, der for de fleste universitetsstuderende og undervisere ikke er deres forstesprog? Denne artikel prover gennem et litteraturreview at finde svar i den eksisterende, forskningsbaserede litteratur. Forste del af reviewet identificerer interesseområder i forskningen, mens anden del gennemgår resultater fra enkelte studier med fokus på læring og deltagelse, særligt i en nordisk kontekst.

\section{Introduktion}

Siden Bologna-deklarationen blev underskrevet i 1999, har ønsket om at skabe "et europæisk område for videregående uddannelser" bl.a. ført til et fokus på studerendes muligheder for at tage uddannelser på tværs af nationalgrænser. I praksis har studentermobilitet betydet, at mængden af undervisning på engelsk på de danske universiteter er steget, og Danmark er i øjeblikket det land i Europa med den højeste andel kurser og programmer udbudt på engelsk (Lauridsen, 2015). Den udvikling forstærkes af, at universitetet som institution i stadig stigende grad forventes at profilere sig og være konkurrencedygtigt på et globalt marked, hvor undervisning er en vare, der kan sælges (se Philipson 2006; Mortensen \& Haberland 2009, 2012). ÆEndring af undervisningssproget til det "globale sprog" engelsk gør det muligt at ekspandere markedet. For at kunne tiltrække studerende og forskere udefra, er det nemlig nødvendigt at undervise på et andet sprog end dansk - i reglen engelsk.

Undervisningen på universiteter i ikke-anglofone områder vil i stadigt stigende grad foregå på et sprog, der for de fleste deltagere hverken er deres første eller bedste sprog, og dette rejser en række spørgsmål, bl.a. om konsekvenserne for kvaliteten af uddannelsesforløbet (se Vinke 1995; Klaassen 2001). Falder læringsudbyttet, når der undervises på et andetsprog? Bliver undervisnings- og læringsaktiviteter påvirket?

Denne artikel prøver dels at finde svar i den eksisterende litteratur, dels at vise et øjebliksbillede af status på forskning, der beskæftiger sig med undervisning på et andetsprog. Andetsprog kan defineres som et sprog tilegnet efter førstesproget i en kontekst, hvor det fungerer som kommunikationsmiddel fx med autoriteter på arbejde eller universitetet (Holmen, 2006). I et universitetspædagogisk perspektiv er læringsudbytte et interessant perspektiv, men det rummer samtidig forskellige aspekter (Illeris, 2006). Når læringsmål i stigende grad udtrykkes som kompetencer, understreger det en forståelse af viden som tæet forbundet med situerede praksisser, og at det ikke blot drejer sig om, hvad man har lært, men også hvordan det er integreret i den øvrige viden og den identitet, man har (fx Ulriksen, 2014). Læring på universitet er derfor både udvikling af faglige kompetencer og socialisering til at blive en del af et fagligt fællesskab. 


\section{Metode}

Dette studie er et litteraturreview af forskningsbaseret litteratur om undervisning på et andetsprog med udgangspunkt i ovenstående spørgsmål, hvor første del af reviewet handler om generelle trends i forskning omkring undervisning på et andetsprog og internationalisering af videregående uddannelser. Anden del fokuserer på de konsekvenser for læringsudbyttet, det kan have at blive undervist på et andetsprog.

Litteratursøgningen er foretaget på ERIC (Education Resources Information Centre, http://www.eric.ed.gov/), hvor søgningen har taget udgangspunkt i følgende: English Medium Instruction, International Education, Language of Learning and Teaching, Integrating Content and Language og Learning through foreign language. Søgningen blev afgrænset til videregående uddannelse og til en tidsramme fra 1995-2015. Tekster, som handlede om undervisning på engelskuddannelser, er sorteret fra. Det er således kun tekster, hvor sproget bruges som medium og ikke er et mål i sig selv, der er medtaget. Tekster om tegnsprog er ligeledes sorteret fra. Søgningen var afgrænset til peerreviewede tekster. Afgrænsningen var dels pragmatisk (ikke peer-reviewet litteratur er tidskrævende at finde), dels ud fra det rationale, at undervisere og planlæggere, som skal udvikle eller undervise på andetsprogsbaserede kurser, vil være henvist til den officielle, overvejende peer-reviewede litteratur. Dog er enkelte afhandlinger, rapporter og bøger så centrale i forskningen, at de alligevel indgår.

I første omgang læstes abstracts af alle tekster fra søgningen for at bekræfte deres relevans for nøgleordene: læring og deltagelse. Tekster uden relevans blev skåret fra, bl.a. om ph.d.-niveau og international publicering. Kategoriseringen af abstracts har til formål at skabe et overblik over temaer i forskningen. Kategorierne opstod ved læsning af abstracts og dannede samtidig rammen for videre læsning. De er altså både et resultat og en del af metoden. Samme tekst kan godt optræde i forskellige kategorier. Teksterne er opdelt i dansk litteratur, øvrig skandinavisk litteratur og international litteratur for at identificere eventuelle forskelle i interesseområder. Opdelingen er foretaget på baggrund af den kontekst, forskningen er udført i, altså har fx dansk litteratur danske universiteter som genstandsområde.

De identificerede kategorier:

- Holdninger:

Indeholder tekster om hhv. studerende, undervisere og andre akademiske medarbejderes holdninger til sprogpolitik, til det at undervise eller blive undervist på engelsk eller til sprog og sprogformer.

- Oplevelse:

Indeholder tekster om studerendes læringsoplevelse eller underviseres oplevelse af at undervise på engelsk, samt erfaringer med eller forventninger til undervisningen.

- Læringsudbytte:

Indeholder tekster om learning outcome, achievement outcome, student performance og academic performance. Altså læring, men også betragtet som præstationer, fx ved eksamener og prøver.

- Undervisning og deltagelse:

Indeholder tekster om studenteraktivitet, fx aktivitet i klasserummet eller at indgå i kommunikation med ligesindede. 
- Sproglige problemer:

Indeholder tekster om sproglige problemer og/eller sproglig support.

- Sprog og identitet:

Indeholder tekster om uoverensstemmelse mellem faglig og sproglig identitet eller anfægtet national identitet. Når man bruger sprog, signalerer man identitet, og identiteten kan blive påvirket, når man taler et sprog, man ikke mestrer til fulde. Derudover kan der være årsager til, at ét sprog har højere prestige end et andet, eller at den nationale identitet i sprogbrugen er stærk.

- Sprogvidenskab:

Indeholder tekster om sproglige fænomener i en international kontekst snarere end selve undervisningssituationen, hovedsageligt engelsk som lingua franca, altså som fællessprog, og kodeskift.

- Internationalisering:

Indeholder sprogpolitiske tekster, tekster om udenlandske studerende/studentermobilitet, samt erfaringer med eller anbefalinger til internationalisering af videregående uddannelse, herunder rekruttering af internationale studerende.

Kategorierne er dannet på baggrund af teksternes selverklærede genstandsområder. Eftersom læring som nævnt rummer flere dimensioner, og fordi kompetencer knytter sig til situationer, kan alle kategorierne have betydning for de studerendes læringsudbytte. Holdninger til sprogbrugen kan påvirke motivationen og den følelsesmæssige side af læreprocessen, sproglige problemer kan have betydning for mulighederne for at deltage i læringsaktiviteter og dermed for udbyttet, og internationaliseringen kan betyde en større spredning i de studerendes forudsætninger, såvel kulturelt som hvilke erfaringer, de har med at indgå i undervisningsaktiviteter. Disse sociale, kulturelle, følelsesmæssige og politiske aspekter kan alle påvirke de studerendes læring sådan, at det, de lærer, bliver noget andet end det, underviseren havde til hensigt, ligesom lærerens forståelse for det ændrede læringsrum kan betyde, at det, læreren gør, bliver til noget andet end det, hun havde til hensigt (Tamir, 1998). Vi har i denne artikel valgt at fokusere på kategorierne Læringsudbytte og Undervisning og deltagelse og har herved altså kun set på selve undervisningssituationen.

Efter kategoriseringen udvalgte vi artikler, der optrådte i de to udvalgte kategorier. De blev nærlæst, og en gennemgang af enkelte særligt relevante tekster er at finde i denne artikels resultatafsnits anden del. Undervejs i kategoriseringen opstod spørgsmål, der guidede tværgående læsning af artiklerne, bl.a.: Hvilken tradition kommer forfatterne fra? Hvilken metode har de brugt? Handler det om undervisning eller uddannelse? Hvem interesserer artiklen sig for - studerende, underviser etc.? Hvilke kendetegn/kriterier bruger de til at vurdere studerendes læring? Er der anbefalinger? På grund af den begrænsede plads kan vi ikke i denne artikel gå nærmere ind i alle spørgsmålene.

\section{Resultater}

Hvad handler teksterne om?

Først vil vi skabe et overblik over de temaer, litteraturen har koncentreret sig om i forbindelse med fagundervisning på et andetsprog ved at gennemgå resultater fra kategoriseringen. 
Dansk litteratur: 46 tekster (se appendix 1)

\begin{tabular}{|l|l|l|l|l|l|l|l|}
\hline Holdninger & $\begin{array}{l}\text { Op- } \\
\text { levelse }\end{array}$ & $\begin{array}{l}\text { Lærings- } \\
\text { udbytte }\end{array}$ & $\begin{array}{l}\text { Under- } \\
\text { visning og } \\
\text { deltagelse }\end{array}$ & $\begin{array}{l}\text { Sproglige } \\
\text { problemer }\end{array}$ & $\begin{array}{l}\text { Sprog } \\
\text { og } \\
\text { identitet }\end{array}$ & $\begin{array}{l}\text { Sprog- } \\
\text { videnskab }\end{array}$ & $\begin{array}{l}\text { Inter- } \\
\text { nationa- } \\
\text { lisering }\end{array}$ \\
\hline 17 & 14 & 1 & 3 & 14 & 3 & 5 & 25 \\
\hline
\end{tabular}

Øvrig skandinavisk litteratur: 35 tekster (se appendix 2)

\begin{tabular}{|l|l|l|l|l|l|l|l|}
\hline Holdninger & $\begin{array}{l}\text { Op- } \\
\text { levelse }\end{array}$ & $\begin{array}{l}\text { Lærings- } \\
\text { udbytte }\end{array}$ & $\begin{array}{l}\text { Under- } \\
\text { visning og } \\
\text { deltagelse }\end{array}$ & $\begin{array}{l}\text { Sproglige } \\
\text { problemer }\end{array}$ & $\begin{array}{l}\text { Sprog } \\
\text { og } \\
\text { identitet }\end{array}$ & $\begin{array}{l}\text { Sprog- } \\
\text { videnskab }\end{array}$ & $\begin{array}{l}\text { Inter- } \\
\text { nationa- } \\
\text { lisering }\end{array}$ \\
\hline 9 & 10 & 3 & 5 & 8 & 0 & 11 & 12 \\
\hline
\end{tabular}

Der viste sig ikke stor ulighed i interesseområderne i den danske litteratur og den øvrige skandinaviske, og denne opdeling viser sig derfor ikke relevant. I de skandinaviske lande, inkl. Danmark, har der særligt været diskussion om brugen af engelsk i uddannelsessektoren jf. kategorien Internationalisering (Phillipson \& Skutnabb-kangas, 1999; Höglin, 2002; Hyltenstam, 2004; Philipson, 2006; Preisler, 2008; Shaw, 2008; Mortensen \& $\mathrm{Ha}$ berland, 2009; Harder, 2009; Bolton \& Kuteeva, 2012; Hultgren, 2014; Kuuteva, 2014). Diskussionerne har især centreret sig om spørgsmål om domænetab og parallelsproglighed. Én definition af domænetab er, at et givent sprog taber et samfundsområde, fx højere uddannelse, til et andet sprog - i dette tilfælde at der ikke tales dansk, og at dansk derfor heller ikke udvikles som sprog for videnskab og akademia. Parallelsproglighed er det begreb, der ligger til grund for sprogpolitikken på de danske universiteter og betyder ideelt set, at to sprog (dansk og engelsk) bruges parallelt inden for $\mathrm{fx}$ det videnskabelige område. Begge diskussioner er særlige for den skandinaviske litteratur og står især stærkt i den danske.

En stor del af den skandinaviske forskning har fokus på holdninger hos undervisere og studerende til at undervise og lære på engelsk (Gunnarsson \& Öhman, 1997; Phillipson \& Skutnabb-Kangas, 1999; Hellekjaer \& Westergaard, 2002; Carroll-Boegh, 2005; Jensen et al., 2009; Tange, 2010; J ensen \& Thøgersen, 2011). Andre har forsøgt at beskrive det sproglige miljø på universitetskurser undervist på engelsk, og det kommer bl.a. til udtryk i studier af kodeskift og placerer sig i kategorien Sprogvidenskab, der markerer sig større i den øvrige skandinaviske litteratur end i den danske (Ljosland, 2008; Björkman, 2010; Söderlundh, 2010). Imidlertid har kun ganske få beskæftiget sig med læringsudbytte. Faktisk havner kun én artikel i Danmark og tre i resten af Skandinavien i denne kategori (Airey, 2009, 2010, Thøgersen \& Airey, 2011, Hellekjær, 2010). 
International litteratur: 131 tekster (se appendix 3)

\begin{tabular}{|l|l|l|l|l|l|l|l|l|}
\hline Holdninger & $\begin{array}{l}\text { Op- } \\
\text { levelse }\end{array}$ & $\begin{array}{l}\text { Lær- } \\
\text { ings- } \\
\text { udbytte }\end{array}$ & $\begin{array}{l}\text { Under- } \\
\text { visning } \\
\text { og del- } \\
\text { tagelse }\end{array}$ & $\begin{array}{l}\text { Sproglige } \\
\text { proble- } \\
\text { mer }\end{array}$ & $\begin{array}{l}\text { Sprog } \\
\text { og } \\
\text { identi- } \\
\text { tet }\end{array}$ & $\begin{array}{l}\text { Sprog- } \\
\text { videnskab }\end{array}$ & $\begin{array}{l}\text { Inter- } \\
\text { natio- } \\
\text { nalise- } \\
\text { ring }\end{array}$ & $\begin{array}{l}\text { Sprog- } \\
\text { kurser }\end{array}$ \\
\hline 38 & 23 & 15 & 13 & 43 & 18 & 7 & 55 & 5 \\
\hline
\end{tabular}

Den internationale litteratur indeholder både forskning fra europæisk og ikke-europæisk kontekst, men udslagsgivende i forhold til interesseområder ser især førstesproget, engelsk eller ikke-engelsk, ud til at være. Kategoriseringen af den internationale litteratur krævede en ekstra kategori, nemlig Sprogkurser, der dækker over effekten af sprogkurser $\mathrm{i}$ forhold til at være rustet til at modtage undervisning på engelsk i et fag, hvor sproget ikke er et eksplicit læringsmål. Dette kan måske hænge sammen med de to kategorier, der ser ud til at dominere, nemlig Sproglige problemer og Internationalisering. I internationaliseringskategorien drejer litteraturen sig primært om udenlandske studerende, og de samme tekster optræder både i denne kategori og i Sproglige problemer. Det lader altså til, at hvor diskussionen om domænetab dominerer den skandinaviske litteratur, er det i den internationale litteratur udenlandske studerende med sproglige problemer, der er centrum for debatten.

Andelen af studier af læringsudbyttet er relativt større i den internationale litteratur. Størstedelen er dog kvantitative sammenligninger af karaktergennemsnit og sprogtests. Det betyder, at det er en relativt snæver forståelse af læringsudbytte, som bliver undersøgt. Sprogtestene siger noget om de studerendes færdigheder men ikke om deres læreproces og læringsudbytte i bredere forstand. Udsagnskraften af karaktererne står og falder med, hvad prøverne måler, og man kan ikke uden videre forudsætte, at et eksamensresultat udtrykker en begrebslig forståelse eller beherskelsen af en kompetence ( $\mathrm{fx}$ Jakobsen et al., 1999), eller at studerende og undervisere har samme opfattelse af bedømmelsen (Fletcher et al., 2012).

\section{Hvad siger teksterne om konsekvenser for læringsudbyttet?}

\section{Forventede konsekvenser af at undervise på et andetsprog}

I det kun ganske få tekster falder i kategorien Læringsudbytte, vil vi først gennemgå de mulige, teoretisk begrundede konsekvenser, det kan have at lære gennem et andetsprog. Derefter vil vi gennemgå enkelte tekster med fokus på empirisk begrundede konsekvenser.

En generel bekymring er, at hvis kompetencen i det sprog, undervisningen foregår på, er dårligere end førstesproget, vil det føre til reduceret faglig kompetence som resultat af enten ufuldstændig forståelse, eller at undervisere tager højde for dette og forsimpler indholdet (Dalton-Puffer, 2011). Desuden kan det synes urimeligt, at studerende skal lære et nyt og svært emne gennem et andetsprog, da det giver dem en dobbelt opgave ift. at mestre både sprog og fagligt indhold (Rolnick, 2000). Denne tankegang kan underbygges af en antagelse af, at når studerende processerer to forskellige opgaver samtidigt, vil deres præstation på den første opgave blive forstyrret af den anden. Dette kaldes inden for teori om kognitiv belastning også for "dual-task". Iflg. denne teori (Sweller et al., 2011) vil undervisning gennem et andetsprog være ineffektiv og forstyrrende for læring, da det forøger den kognitive belastning. Det vil sige, at hvis et individ har begrænset hukommelseskapacitet, og en opgave overstiger den kognitive kapacitet, vil læringen blive forstyrret, og den studerende vil ikke udvikle ny viden. Omvendt argumenterer Cummins (1991) for, at en underliggende dygtighed afgør et individs præstation i 
kognitive og akademiske opgaver både på førstesproget og på andetsproget (se også Gerber et al., 2005).

I enhver undervisningssituation kan man tale om, at der bruges to sprog: et almindeligt talt hverdagssprog og et fagspecifikt videnskabeligt sprog. Forskellen på hverdagssprog og eksempelvis matematisk terminologi fører til, at også førstesprogstalende skal lære et nyt sprog, når de lærer et nyt fag. Östman (1998) foreslår, at fagligt sprog er abstrakt og repræsenterer specielle kommunikative traditioner og forudindtagelser. Halliday og Martin (1993) hævder, at sprog er mere end simpel repræsentation af faglig viden; det er også med til aktivt at facilitere denne viden, og det at lære et fag vil derfor afhænge af at lære fagets sprog. Således kan man argumentere for, at forholdet mellem en studerendes førstesprog og læring ikke er ligefremt.

\section{Empiriske undersøgelser af konsekvenser}

Vi vil nu gennemgå de fire skandinaviske tekster, der optrådte i kategorien Læringsudbytte (Airey, 2009; 2010; Thøgersen \& Airey, 2011; Hellekjær, 2010). For at give et mere nuanceret billede af disse resultater, vil vi supplere med resultater fra den internationale litteratur og fra tekster, der optrådte i kategorien Undervisning og deltagelse.

Aireys ph.d.-afhandling (2009) undersøger på baggrund af klasserumsobservation og interviews læringsmønstre hos studerende på et svensk fysikstudium, bl.a. med fokus på undervisningssprog. Læring er her karakteriseret ved at opnå evne til at bruge semiotiske resurser i overensstemmelse med den disciplinære diskurs. Det viste sig, interessant nok, at de studerende hævdede, at der var få forskelle på at blive undervist på hhv. svensk, førstesproget, og engelsk, andetsproget, og at sprog spillede en ubetydelig rolle for deres læring. Imidlertid kunne videooptagelser af undervisningen vise, at der var flere, vigtige forskelle. Forskellene involverede reduceret mængde spørgsmål, større fokus på notetagning på bekostning af at følge underviserens tankegang, og at de studerende ændrede læringsstrategi for at håndtere sprogskiftet, fx ved at stille spørgsmål efter forelæsningen. De studerende var imidlertid ikke bevidste om ændringerne, før de efterfølgende blev konfronteret med dem. Reduktion i frekvensen af spørgsmål er også observeret af Björkman (2010), og flere undersøgelser, ikke kun i Skandinavien, har vist, at undervisningen bliver relativt mere monologisk og mindre interaktiv, når sproget skiftes til engelsk. Hollandske studier viser ligeledes, at de studerende bliver mere passive i klasserummet (Klaassen, 2001; Vinke, 1995).

I tilknytning til undervisning er den enkelte studerende stillet over for to opgaver, nemlig at forstå og at udtrykke. Airey (2010) fokuserer ikke nødvendigvis på, hvor meget eller lidt de studerende har lært, men hvor godt de udtrykker det, og han lægger sig derved op ad et formidlingsorienteret læringsbegreb. Undersøgelsen sammenligner studerendes forklaring af begreber på to sprog på baggrund af transskriptioner fra interviews lavet med svenske studerende på naturvidenskabelige uddannelser. Resultaterne viser, at engelsk skabte problemer for enkelte studerende, og at de havde svært ved at forklare begreber pga. dårligt engelskniveau. Det er ikke muligt ud fra Aireys undersøgelse at udlede, om problemerne kun var et produkt af dårlige sprogkundskaber, eller om de studerende også havde problemer med at følge undervisningen. Andre studerende i undersøgelsen havde ingen problemer, og for nogen var engelsk det sprog, de forklarede sig bedst på. På baggrund af de resultater konkluderer Airey, at over et vist niveau af engelsk er de studerende lige gode til at forklare begreber på begge sprog uanset undervisningssprog. Dette skal ikke forstås sådan, at de lærer lige så godt, kun at de forklarer sig lige så godt. Dog taler de studerende generelt langsommere på engelsk, også selvom de forstår begrebet, og han anbefaler derfor, at man som underviser tager forbehold for, at langsom tale ikke nødvendigvis er et udtryk for dårlig forståelse. 
Hellekjærs norske studie (2010) behandler læring som forståelse af forelæsninger ved gennem et spørgeskema at undersøge, hvor meget studerende på flere fakulteter fik ud af forelæsninger både på deres førstesprog og på et andetsprog. Hellekjærs resultater viser, at de fleste studerende ikke ser ud til at have seriøse vanskeligheder med at modtage undervisning på et andetsprog. Det er særligt interessant at bemærke, at de problemer, han identificerer i forelæsninger på engelsk, er meget lig de problemer, der kan være med forelæsninger på et førstesprog, dog i en mindre grad. Det synes altså sandsynligt, at problemer med fagspecifik terminologi er de samme på førstesproget som på engelsk, og at læring af terminologien går hånd i hånd med læring af konceptet. Studiet viser yderligere, at de studerende, der ser sig selv arbejde i en international sammenhæng, er dygtigst på engelsk. Vigtigheden, de føler af engelsk for fremtidig karriere, $ø$ ger deres indsats $\mathrm{i}$ at mestre undervisning på et fremmedsprog. Dette minder om resultater fra Nissen (2015).

Der er to sider af en undervisningssituation. Den ene er at blive undervist og den anden at undervise. Begge kan blive påvirket, når undervisningssproget ændres. Et nordisk samarbejde af Thøgersen \& Airey (2011) behandler pædagogiske konsekvenser ved at skifte undervisningssprog, og de behandler derved også den effekt, det kan forventes at have på læringsudbyttet. Undersøgelsen er dels kvantitativ, dels kvalitativ i komparation af naturvidenskabelige underviseres tale både på førstesproget, dansk, og på andetsproget, engelsk. På den ene side analyseres talehastigheden og på den anden talens retoriske stil. Det viser sig, at samme præsentation tager længere tid på andetsproget end på førstesproget. For det første gives studerende mere tid til at overveje en given information. Faktisk gives de ca. 50\% længere tid til at forstå og behandle sætningen. For det andet bliver de studerende præsenteret for et ekstra fagcentralt synonym til at forklare begrebet, og der bygges på den måde stærkere forbindelser mellem den centrale terminologi. De studerende, der bliver undervist på dansk, præsenteres for mere verbalt materiale, idet underviserne bruger flere ord og flere måder til at forklare begrebet på. Modsat hvad man kunne forestille sig, er det i denne undersøgelse ikke undervisningen på engelsk, der har et mindre specifikt ordforråd, men undervisningen på førstesproget. Det skyldes, at de engelske forelæsninger har en mere formel stil tæet på tekstbogssprog, hvor de danske har mere uformelle sprogstrukturer (se også Thøgersen, 2013). Thøgersen \& Airey argumenterer for, at undenviseren måske er nødt til at ændre pædagogisk stil, fordi det engelsk, hun har adgang til, er tekstbogsengelsk. I det tilfælde vil underviseren i et pædagogisk perspektiv være mere fattig på engelsk. Dog mener de også, at det er tænkeligt, at de studerende finder det lettere at håndtere en formel beskrivelse gentaget flere gange end det samme indhold formuleret på forskellige måder i hverdagssprog.

Hvis vi kigger uden for Europa, kan et sydafrikansk studie af Paxton (2009) give indsigt i, hvordan studerende håndterer læringssituationen på et andetsprog i en undersøgelse, der ligesom Aireys (2010) beder studerende forklare begreber på to sprog og i øvrigt give eksempler på, hvordan man bruger dem. I afrikanske sprog er der ord inden for bl.a. akademiske domæner, der ikke er en etableret del af sproget, fordi der ikke er udviklet fagterminologi. Når studerende skal lære et givent fags sprog, flyttes de fra hverdagssprog til et specialiseret domæne, og det er et afgørende skridt i undervisnings- og læreprocesser. Studiet viser, at de studerende oversætter begreber til deres førstesprog for at forstå dem, men hvis der ikke findes et ord på sproget, finder de det betydningsmæssigt nærmest beslægtede. Da ordene ikke betyder helt det samme, făr de imidlertid en utilstrækkelig forståelse af begrebet, og i værste fald misforstår de. Nogle af de svenske studerende syntes at bruge samme strategi, idet de brugte det, der kaldes en false friend, dvs. et ord, der ligner ordet på deres førstesprog, men som har en anden betydning på det andet sprog. 
Hvis det at oversætte begrebet imidlertid ikke syntes tilstrækkeligt for de sydafrikanske studerendes forståelse, fandt de, at den eneste løsning var at huske ordet uden at forstå det og derved ty til overfladelæring (Biggs \& Tang, 2011). Paxtons studie konkluderer altså, at læring af økonomiske koncepter bliver begrænset af kun at bruge andetsproget, og at undervisere måske ikke er opmærksomme på, at skriftligt arbejde kan gemme på misforståelser, idet studerende ikke fuldt forstår den engelske tekst, men blot memorerer den. I følge Paxton kan en løsning være at lade de studerende bruge begge sprog i diskussioner med ligesindede, og at de derved måske kan opnå en dybere forståelse af begrebet, end hvis kun det ene sprog bruges.

I den internationale litteratur peger Gerber et al. (2005), Klaassen (2001), Neville-Barton \& Barton (2005) og Vinke (1995) på negative korrelationer mellem faglig præstation og ændring af undervisningssprog, og New Zealandske studier viser, at studerende undervist på et andetsprog præsterer $10 \%$ dårligere end studerende undervist på førstesprog (Barton \& Neville-Barton, 2003; Neville-Barton \& Barton, 2005). Lignende forhold findes til en vis grad hos Gerber et al. (2005) i et studie af afrikaans-talendes læring af matematik på engelsk, men hvor den matematiske evne dog viser sig vigtigere for præstationen end sproglige kompetencer. I Klaassens studie (2001) udlignede forskellene sig over tid, og ingen af ovenstående studier kan sige noget endegyldigt om, hvorvidt læringsudbyttet falder, når undervisningssproget skiftes.

\section{Diskussion og konklusion}

I første del af reviewet viste vi en forskel i temaer i skandinaviske og i internationale studier af undervisning på engelsk. Hvor de skandinaviske lande var optaget af domænetab, fokuserede den internationale litteratur på sprogvanskeligheder og internationalisering. Forskellene afspejler de nationale udgangspunkter: For de nordiske lande betyder internationaliseringen et skift fra nationalsprog til engelsk, og det giver anledning til overvejelser. For engelsktalende lande betyder internationalisering flere studerende med andre sproglige forudsætninger.

Den skandinaviske litteraturs vægt på holdninger og oplevelse af undervisning på engelsk kan måske skyldes en interesse for de aktører, som skal forvalte ændringen af undervisningssprog og måske også en interesse for de politiske sider af sagen. Mens den skandinaviske litteratur indeholder indirekte undersøgelse af læringsudbyttet gennem studier af de studerendes måde at deltage i undervisningen på (jf. senere), så er det imidlertid påfaldende få studier, som direkte undersøger det konkrete læringsudbytte. Det kan skyldes, at det er metodisk vanskeligt at gennemføre kontrollerede undersøgelser af sprogets betydning for læringsudbytte, som kan indfange de mere komplekse, kompetenceorienterede læringsmål, som ofte vil findes på videregående uddannelser. Det kan også hænge sammen med, at der i Skandinavien ikke er en stærk forskningstradition for at måle læringsudbytte, netop fordi der er en bekymring for forsimpling af læringsmålet for at gøre det målbart. Selv om det er en reel bekymring, giver det omvendt et problem i diskussionen af, hvilke konsekvenser fx skift i undervisningssproget har for de studerende.

Vægtningen af den skandinaviske litteratur skal også ses i lyset af relativt få studier og af, at en del af studierne er gennemført af de samme forfattere, som måske har bestemte interesseområder. Tallene kan således både afspejle et uudviklet forskningsfelt og en manglende interesse for læringsudbytte.

De få empiriske undersøgelser af læringsudbytte, selv hvis man inddrager den internationale litteratur, giver ikke noget klart svar på spørgsmålet om, hvilken konkret betydning undervisning på et andetsprog har for læringsudbyttet. Klaassens studie antyder, at læringsudbyttet falder, når man skifter undervisningssprog, men det er værd at bemærke, at det udligner sig over tid, efterhånden som de studerende vænner sig til sprogskiftet. 
Airey og kolleger siger ikke noget direkte om læringsudbytte, men ud fra de effekter på de studerendes deltagelse og undervisernes praksis, som undersøgelserne afdækker, kan man sige, at det er overvejende sandsynligt, at det sproglige medium har en indirekte betydning for de studerendes læringsudbytte. Det hænger sammen med, at de praksisser, Airey m.fl. finder, i anden universitetspædagogisk forskning er knyttet til mere overfladisk læring (fx Prosser and Trigwell, 1999).Omvendt betyder det også, at nogle af de forhold, som findes i den engelsksprogede undervisning, også findes i undervisning på førstesproget. De studerende gør, hvad de kan for at klare kurset uafhængigt af kvaliteten af undervisning. Undervisning på et andetsprog fremhæver altså til en vis grad problemer, der måske allerede er der.

Paxtons sydafrikanske studie understreger, at sprog hænger sammen med kultur, og at det derfor ikke blot er et spørgsmål om sprogfærdighed - en pointe som er parallel med Halliday og Martins sprogsyn. De studerendes forståelsesstrategier i oversættelsen mellem forskellige faglige sprog, men også mellem forskellige erfaringsverdener kan have betydning for, hvor korrekt de studerende forstår det faglige indhold. På den måde handler undervisning på andetsprog også om at være opmærksom på kulturelle forhold, som spiller ind på de studerendes forståelse.

Samlet set vil vi pege på to konklusioner og perspektiver fra dette review. Det første er, at diskussionen om brug af engelsk som undervisningssprog på videregående uddannelser kræver en langt mere nuanceret forståelse end engelsksproglige kompetencer. Sprog er knyttet til kultur og identitet og er forbundet med forståelse på flere måder end gennem semantikken. Sproget er også knyttet til de studerendes og undervisernes praksisser i læringsrummet og dermed til den måde, hvorpå disse praksisser understøtter eller hæmmer læring. Diskussionen kræver nuancer.

Det andet er, at der er brug for flere undersøgelser, som målrettet og nuanceret søger at afdække de studerendes læringsudbytte. Sådanne undersøgelser er komplekse, fordi så mange forhold påvirker læringsudbyttet. Det gælder ikke kun studier af effekten af undervisningssprog, men af undervisning i det hele taget. Der er derfor brug for studier, som med forskellige metoder undersøger læringsudbyttet i bred forstand. Sådanne studier vil ikke kunne formulere ét svar på, hvilken betydning undervisningssproget har; men det vil kunne kvalificere diskussionen, og i lyset af omfanget af engelsksproget undervisning på danske uddannelser vil det være meget relevant. Et relevant aspekt er, om en ændring i undervisningssproget kan have forskellig betydning i forskellige fagområder. En stor del af de nordiske studier har undersøgt naturvidenskabelige uddannelser, men det er muligt, at forskelle i læringsindhold og undervisningstraditioner kan betyde, at man ikke nødvendigvis uden videre kan overføre resultater fra ét fagområde til et andet. Tilsvarende kan der være forskelle i konsekvensen på tværs af kulturer - herunder undervisningskulturer - som svækker undersøgelsernes udsagnskraft. Flere, nuancerede og sammenlignende studier vil derfor være kærkomne.

Som underviser kan man holde sig for øje, at selvom studerende (og undervisere) skulle mene, at det er uden betydning at kunne tale et fremmedsprog, så gør det en forskel for nuancerne og følelsen af sikkerhed. Det vil kunne afhjælpes ved en opmærksomhed på at skabe et trygt læringsrum, at give de studerende muligheder for at tale i mindre grupper, åbne for at bruge modersmålet også og ved at forvente langsommere og mere tøvende tale - som ikke skal forveksles med faglig usikkerhed.

Tilsvarende bliver studerende mere tilbøjelige til at blive mere passive og anlægge overfladestrategier. Det taler for en (endnu mere) bevidst brug af studenterinddragelse, små øvelser og gruppediskussioner, refleksion, tænkeskrivning osv. - dvs. teknikker som tilskynder de studerende til at arbejde aktivt med indholdet og tilbyder tid og rum til at gøre det. 
Væsentligst er det dog, at underviseren er opmærksom på, at der er forskel på at undervise på modersmålet og på engelsk - også selv om det ikke kan afgøres præcist, hvilken betydning forskellen har.

Camilla Falk Rønne Nissen er ph.d.-studerende i Dansk ved Institut for Nordiske Studier og Sprogvidenskab. Hendes ph.d.-projekt handler om de sproglige og pæedagogiske konsekvenser, som internationalisering af universitetet medfører. I 2015 blev Camillas empirisk baserede speciale udgivet af Center for Internationalisering og Parallelsproglighed. Her findes et etnografisk studie af det sproglige miljø på to engelsksprogede kurser på Københavns Universitet.

Lars Ulriksen er professor i Naturfagenes Uddannelsessociologi ved Institut for Naturfagenes Didaktik på Københavns Universitet. Hans primæere forskningsinteresse er mødet mellem deltagerne og uddannelser, herunder uddannelsernes opbygning, de undervisningsformer som bruges, og hvad det forudsætter hos deltagerne - ikke mindst hos de studerende. Han har undervist på adjunktpædagogikum siden 1999 og udgav i 2014 bogen God undervisning på de videregående uddannelser (Fryden/und).

\section{Litteratur}

Airey, J. (2009). Science, Language and Literacy: Case Studies of Learning in Swedish University Physics. (PhD thesis). Uppsala: Acta Universitatis Upsaliensis. Retrieved from http://www.diva-portal.org/smash/get/diva2:173193/FULTEXT01.pdf.

Airey, J. (2010). The ability of students to explain science concepts in two languages. Hermes - Journal of Language and Communication Studies ,45, 35-49.

Barton, B. \& Neville-Barton, P. (2003). Language issues in undergraduate mathematics: Report of two studies. New Zealand Journal of Mathematics, 32, 19-28.

Biggs, J. B. \& Tang, C. (2011). Teaching for Quality Learning at University. What Students do (3. Edition). Maidenhead: Society for Research into Higher Education \& Open University Press, McGraw-Hill Education.

Björkman, B. (2010). Spoken Lingua Franca English at a Swedish Technical University: An Investigation of Form and Communicative Effectiveness. Unpublished PhD thesis. Stockholm: Stockholm University.

Bolton, K. \& Kuteeva, M. (2012). English as an academic language at a Swedish university: Parallel language use and the "threat" of English. Journal of Multilingual and Multicultural Development, 33(5), 429-447.

Carroll-Boegh, A. (2005). Internationalisation and teaching through English: A Danish perspective. Educate, 5(2), 19-30.

Cummins, J. (1991). Interdependence of first and second language proficiency in bilingual children. I: E. Bialystok (red.): Language processing in bilingual children, 70-89. Cambridge, UK: Cambridge University Press.

Dalton-Puffer, C. (2011). Content and language integrated learning: From practice to principles? Annual Reviews of Applied Linguistics, 31, 182-204.

Fletcher, R. B., Meyer, L. H., Anderson, H., J ohnston, P. \& Rees, M. (2012). Faculty and students conceptions of assessment in higher education. Higher Education, 64(1), 119-133. doi: 10.1007/s10734-011-9484-1.

Gerber, A., J., Engelbrecht, Harding, A. \& Rogan, J. (2005). The influence of second language teaching on undergraduate mathematics performance. Mathematics Education Research Journal,17, 3-21.

Gunnarsson, B.-L. \& Öhman, K. (1997). Det internationaliserade universitetet. En studie av bruket av engelska och andra främmande språk vid Uppsala Universitet. TeFa 16. Uppsala: Uppsala universitet, Department of Scandinavian Languages.

Halliday, M. A. K. \& Martin, J. R. (1993). Writing Science: Literacy and Discursive Power. London: Falmer. 
Harder, P. (red.) (2009). Angles on the English-Speaking World: English in Denmark; Language Policy, Internationalization and University Teaching. København: Museum Tusculanum.

Hellekjær, G. O. (2010). Language matters: Assessing lecture comprehension in Norwegian English-medium higher education. I: C. Dalton-Puffer, T. Nikula \& U.J .B. Smit (red.): Language Use and Language Learning in CLIL Classrooms, 233258. Amsterdam: J ohn Benjamins.

Hellekjær, G. O. \& Westergaard, M. R. (2002). An exploratory survey of content learning through English at Scandinavian universities. I: A. M. Simensen (red.): Teaching and learning foreign languages issues and ideas, 47-61. Oslo: Unipub.

Höglin, R. (2002). Engelska språket som hot och tillgång i Norden. Köpenhamn: Nordiska ministerrådet.

Holmen, Anne (2006): Finding a voice in a second language. I: Ø. Dahl, I. J ensen \& P. Nynäs (red.): Bridges of Understanding. Perspectives on Intercultural Communication. Oslo: Unipub forlag.

Hultgren, A. K. (2014). Whose parallellingualism? Overt and covert ideologies in Danish university language policies. Multilingua. Journal of cross-cultural and interlanguage communication, 33(1-2), 61-87.

Hyltenstam, K. (2004). Engelskan, skolans språkundervisning och svensk språkpolitik. I: O. Josephson \& B. Lindgren (red.): Engelskan i Sverige. Språkval i utbildning, arbete och kulturliv, 36-110. Stockholm: Svenska Språknämnden.

Illeris, K. (2006). Læring (2. reviderede udg.). Frederiksberg: Roskilde Universitetsforlag.

Jakobsen, A., Rump, С. Ø., Clemmensen, T. \& May, M. (1999). Kvalitetsudviklingsprojektet "Faglig Sammenhæeng" Hovedrapport (Vol. 1). Lyngby: Center for Didaktik og Metodeudvikling, Danmarks Tekniske Universitet.

J ensen, C. \& Thøgersen, J. (2011). Danish University lecturers' attitudes towards English as the medium of instruction. /bérica, 22, 13-34.

J ensen, C., Stæhr, L. S., Thøgersen, J. \& Nielsen, J. Ø. (2009). Underviseres holdninger til engelsk som undervisningssprog: En spørgeskemaundersøgelse på Københavns Universitet. Center for Internationalisering og Parallelsproglighed. København: Museum Tusculanum . http://cip.ku.dk/forskning/publikationer/.

Klaassen, R. (2001). The International University Curriculum: Challenges in English medium Engineering Education. Unpublished Doctoral Thesis, Delft University of Technology.

Kuteeva, M. (2014). The parallel language use of Swedish and English: The question of "nativeness" in university policies and practices. Journal of Multilingual and Multicultural Development, 35(4), 332-344.

Lauridsen, K. (2015). International programmes or English medium instruction. Præsentation på Dansk Universitetspædagogisk Netværks Konference 2015

Ljosland, R. (2008). Lingua franca, prestisjespråk og forestilt fellesskap: Om engelsk som akademisk språk i Norge. Et kasusstudium i bred kontekst. Unpublished PhD thesis. Norwegian University of Science and Technology.

Mortensen, J. \& Haberland, H. (2009). Sprogvalg på danske universiteter i historisk perspektiv. Sprogforum, 46, 8-13.

Mortensen, J. \& Haberland, H. (2012). English - the new latin of academia? Danish universities as a case. International Journal of the Sociology of Language, 216, 175-197.

Neville-Barton, P. \& Barton, B. (2005). The Relationship between English Language and Mathematics Learning for Non-native Speakers. Wellington: Teaching and Learning Research.

Nissen, C. F. R. (2015). En parallelsproglig virkelighed - et etnografisk studie af sprogbrugsmønstre på to kurser udbudt på engelsk på SCIENCE og SUND, Københavns Universitet. Københavnerstudier i tosprogethed. Studier i Parallelsproglighed, bind C7. København: Københavns Universitet, Humanistisk Fakultet. 
Paxton, M. I. J . (2009). "It's easy to learn when you using your home language but with English you need to start learning language before you get to the concept": Bilingual concept development in an English medium university in South Africa. Journal of Multilingual and Multicultural Development, 3044), 345-359.

Phillipson, R. (2006). English, a cuckoo in the European higher education nest of languages? European Journal of English Studies, 101), 13-32.

Phillipson, R. \& Skutnabb-Kangas, T. (1999). Englishisation: One dimension of globalisation. I: D. Graddol \& U. H. Meinhof (red.): English in a Changing World. AlLA Review, 13, 19-36. Guilford: AlLA.

Prosser, M. \& Trigwell, K. (1999). Understanding Learning and Teaching. The Experience in Higher Education. Buckingham: Open University Press.

Preisler, B. (2008). Teaching in a foreign language: Linguistic performance and academic authority in the international university. I: H. Haberland, J. Mortensen, A. Fabricius, B. Preisler, K. Risager \& S. Kjærbeck (red.): Higher Education in the Global Village. Department of Culture and I dentity, Roskilde University

Rolnick, M. (2000). Current issues and perspectives on second language learning of science. Studies in Science Education, 35, 9-121.

Shaw, P. (2008). Engelska som lingua franca och som internationellt vetenskapsspråk. I: E. Jansson (red.): Vetenskapsengelska - med svensk kvalitet?, 21-34. Stockholm: Språkrådet.

Söderlundh, H. (2010). Internationella universitet - lokala språkval. Om bruket av talad svenska i engelskspråkiga kursmiljöer. Uppsala: Institutionen för Nordiska Språk, Uppsala Universitet.

Sweller, J, Ayres, P. \& Kalyuga, S. (2011). Cognitive Load Theory. New York, NY: Springer.

Tamir, P. (1998). Assessment and evaluation in science education: Opportunities to learn and outcomes. I: B. J. Fraser \& K. G. Tobin (red.): International Handbook of Science Education, 761-789. Dordrecht/Boston/London: Kluwer Academic Publishers.

Tange, H. (2010). Caught in the Tower of Babel: University lecturers' experiences with internationalization. Journal of Language and International Communication, 10, 137-49.

Thøgersen, J. \& Airey, J. (2011). Teaching undergraduate science in Danish and in English: A comparison of speaking rate and rhetorical style. English for Specific Purposes 30, 209-221.

Thøgersen, J. (2013). Stylistic and pedagogical consequences of university teaching in English in Europe. I: H. Haberland, D. Lønsmann \& B. Preisler (red.): Language Alternation, Language Choice, and Language Encounter in International Tertiary Education. Berlin: Springer.

Ulriksen, Lars (2014). God undervisning på de videregående uddannelser. Frederiksberg: Frydenlund.

Vinke, A. A. (1995). English as the Medium of Instruction in Dutch Engineering Education. Unpublished Doctoral Thesis, Delft University of Technology.

Östman, L. (1998). How companion meanings are expressed by science education discourse. I: D. Roberts \& L. Östman (red.): Problems of Meaning in Science Education, 54-70. New York: Teachers College Press. 
Appendix 1: Dansk litteratur

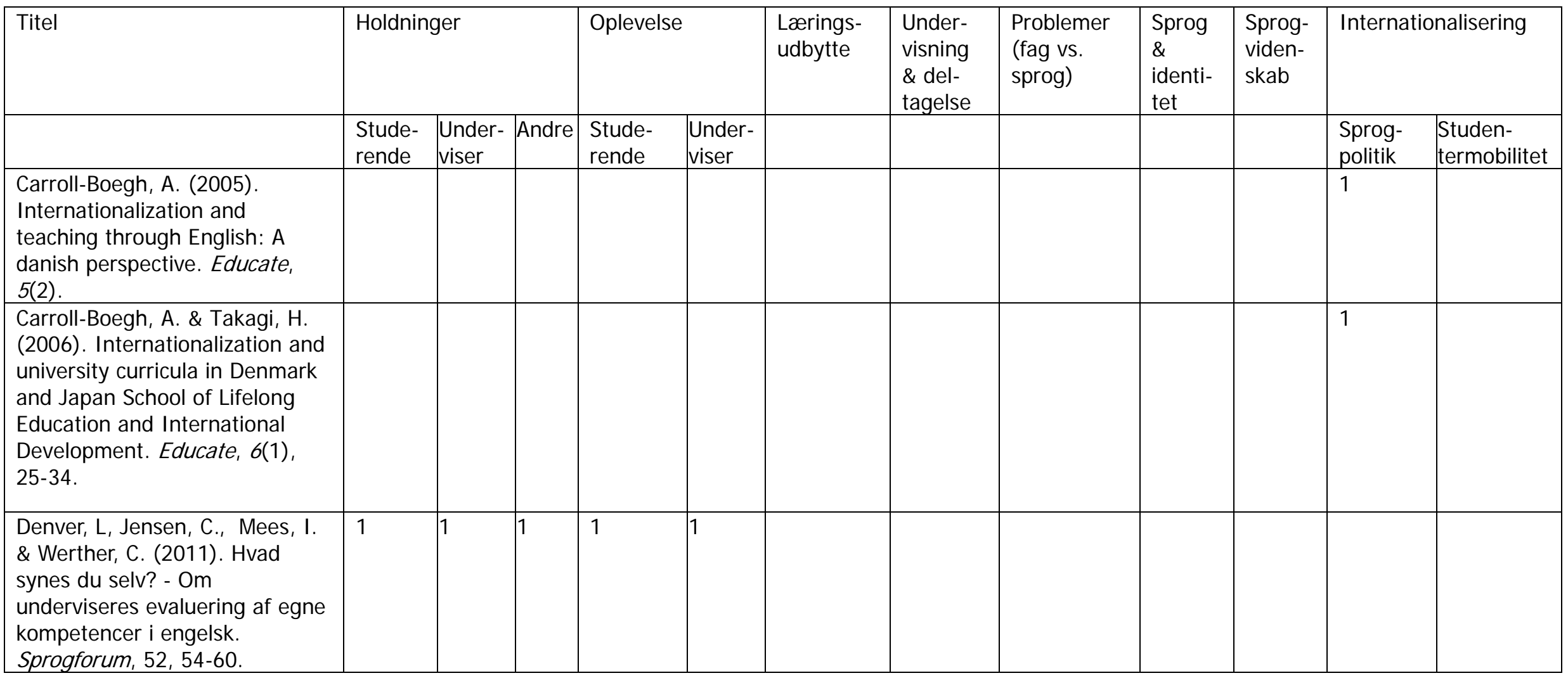




\begin{tabular}{|c|c|c|c|c|c|c|c|c|c|c|c|c|}
\hline \multirow[t]{2}{*}{ Titel } & \multicolumn{3}{|c|}{ Holdninger } & \multicolumn{2}{|c|}{ Oplevelse } & \multirow{2}{*}{$\begin{array}{l}\text { Lærings- } \\
\text { udbytte }\end{array}$} & \multirow{2}{*}{\begin{tabular}{|l|} 
Under- \\
visning \& \\
deltagelse \\
\end{tabular}} & \multirow{2}{*}{\begin{tabular}{|l|} 
Problem- \\
er (fag vs. \\
sprog) \\
\end{tabular}} & \multirow{2}{*}{\begin{tabular}{|l|} 
Sprog \& \\
identi- \\
tet \\
\end{tabular}} & \multirow{2}{*}{$\begin{array}{l}\text { Sprog- } \\
\text { viden- } \\
\text { skab }\end{array}$} & \multicolumn{2}{|c|}{ Internationalisering } \\
\hline & $\begin{array}{l}\text { Stude- } \\
\text { rende }\end{array}$ & $\begin{array}{l}\begin{array}{l}\text { Under- } \\
\text { viser }\end{array} \\
\end{array}$ & Andre & $\begin{array}{l}\text { Stude- } \\
\text { rende }\end{array}$ & $\begin{array}{l}\text { Under } \\
\text {-viser }\end{array}$ & & & & & & $\begin{array}{l}\text { Sprog- } \\
\text { politik }\end{array}$ & $\begin{array}{l}\text { Studen- } \\
\text { termobilitet }\end{array}$ \\
\hline
\end{tabular}




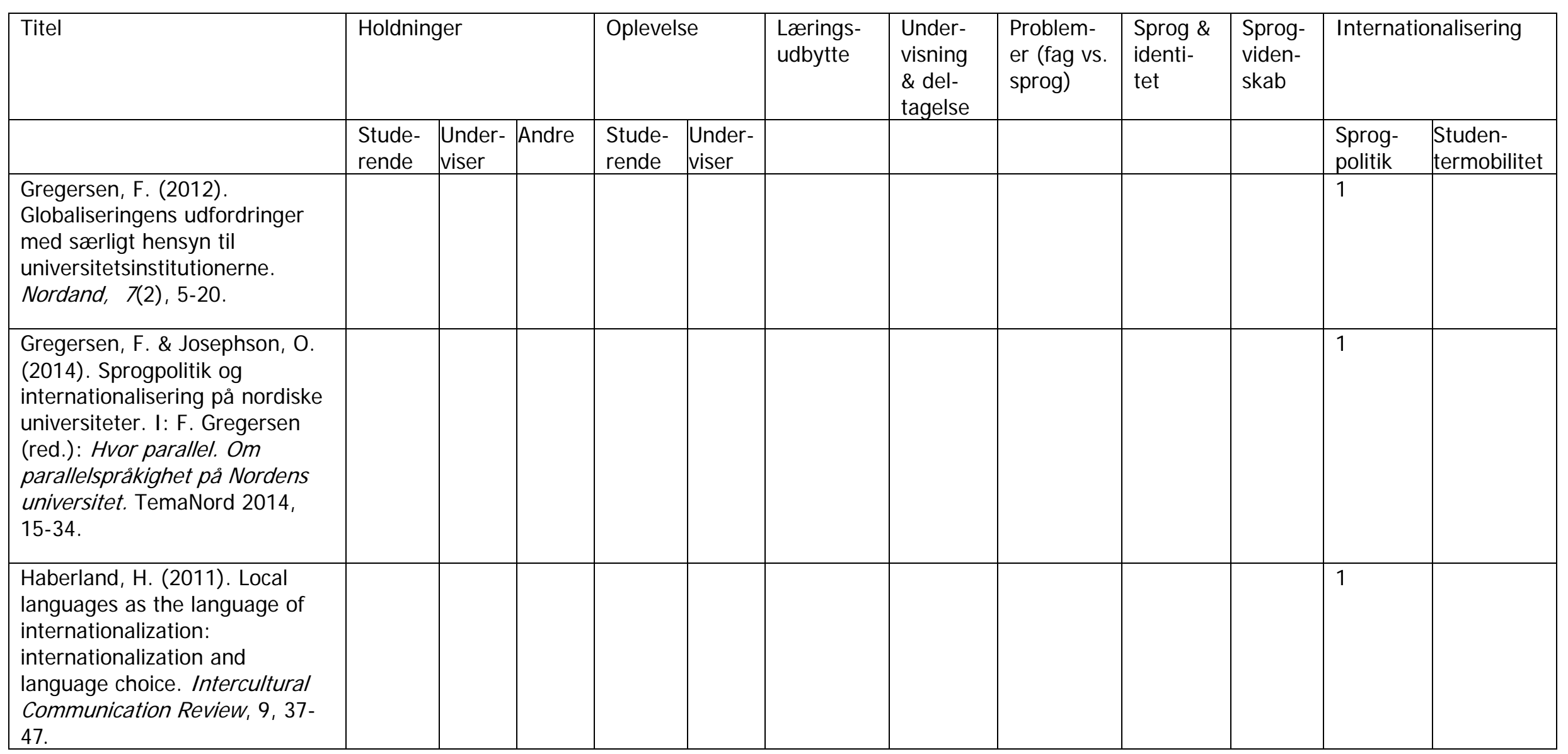




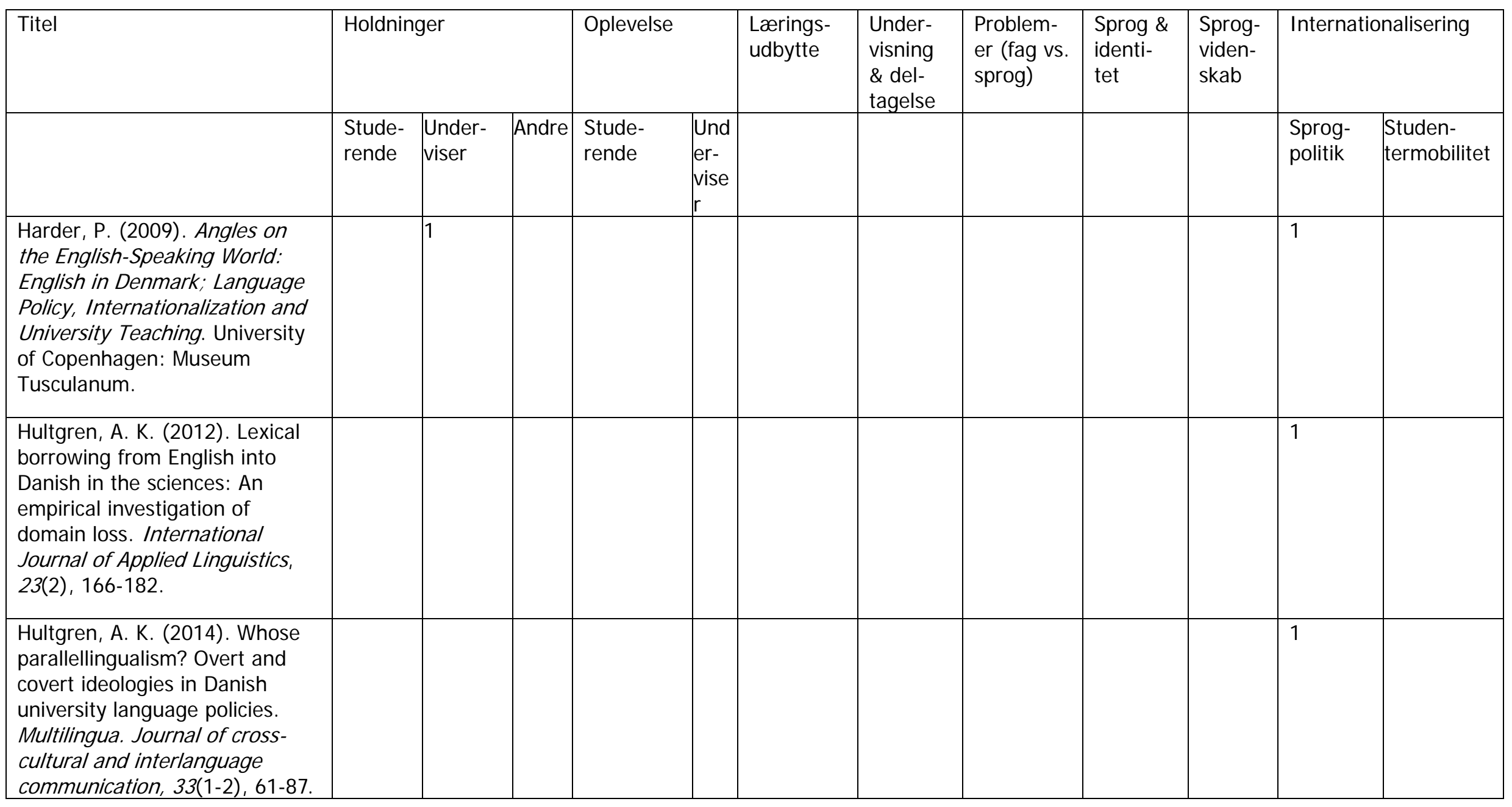




\begin{tabular}{|c|c|c|c|c|c|c|c|c|c|c|c|c|}
\hline \multirow[t]{2}{*}{ Titel } & \multicolumn{3}{|c|}{ Holdninger } & \multicolumn{2}{|c|}{ Oplevelse } & \multirow{2}{*}{$\begin{array}{l}\text { Lærings- } \\
\text { udbytte }\end{array}$} & \multirow{2}{*}{$\begin{array}{l}\text { Under- } \\
\text { visning } \\
\& \text { del- } \\
\text { tagelse }\end{array}$} & \multirow{2}{*}{$\begin{array}{l}\text { Problem- } \\
\text { er (fag vs. } \\
\text { sprog) }\end{array}$} & \multirow{2}{*}{$\begin{array}{l}\text { Sprog \& } \\
\text { identi- } \\
\text { tet }\end{array}$} & \multirow{2}{*}{$\begin{array}{l}\text { Sprog- } \\
\text { viden- } \\
\text { skab }\end{array}$} & \multicolumn{2}{|c|}{ Internationalisering } \\
\hline & $\begin{array}{l}\text { Stude- } \\
\text { rende }\end{array}$ & $\begin{array}{l}\text { Under- } \\
\text { viser }\end{array}$ & Andre & $\begin{array}{l}\text { Stude- } \\
\text { rende }\end{array}$ & $\begin{array}{l}\text { Under } \\
\text {-viser }\end{array}$ & & & & & & $\begin{array}{l}\text { Sprog- } \\
\text { politik }\end{array}$ & $\begin{array}{l}\text { Studen- } \\
\text { termobi-litet }\end{array}$ \\
\hline $\begin{array}{l}\text { Hultgren, A. K., Gregersen, F. \& } \\
\text { Thøgersen, J. (red.) (2014). } \\
\text { English in Nordic Universities: } \\
\text { /deologies and Practices. } \\
\text { Amsterdam: J ohn Benjamins } \\
\text { Publishing Company. }\end{array}$ & & & & & & & & & & 1 & 1 & \\
\hline $\begin{array}{l}\text { Jakobsen, A. S. (2010). "Ellers } \\
\text { er det bare lige ud af } \\
\text { landevejen" - en } \\
\text { interviewundersøgelse af ti } \\
\text { underviseres holdninger til og } \\
\text { erfaringer med engelsksproget } \\
\text { undervisning ved Det } \\
\text { Biovidenskabelige Fakultet, KU. } \\
\text { (Studier i Parallelsproglighed, } \\
\text { bind C2, Københavnerstudier i } \\
\text { Tosprogethed). København: } \\
\text { Københavns Universitet, } \\
\text { Humanistisk fakultet. }\end{array}$ & & 1 & & & 1 & & & & & & & \\
\hline
\end{tabular}




\begin{tabular}{|c|c|c|c|c|c|c|c|c|c|c|c|c|}
\hline \multirow[t]{2}{*}{ Titel } & \multicolumn{3}{|c|}{ Holdninger } & \multicolumn{2}{|c|}{ Oplevelse } & \multirow{2}{*}{$\begin{array}{l}\text { Lærings- } \\
\text { udbytte }\end{array}$} & \multirow{2}{*}{$\begin{array}{l}\text { Under- } \\
\text { visning } \\
\& \text { del- } \\
\text { tagelse }\end{array}$} & \multirow{2}{*}{$\begin{array}{l}\text { Problem- } \\
\text { er (fag vs. } \\
\text { sprog) }\end{array}$} & \multirow{2}{*}{$\begin{array}{l}\text { Sprog \& } \\
\text { identi- } \\
\text { tet }\end{array}$} & \multirow{2}{*}{$\begin{array}{l}\text { Sprog- } \\
\text { viden- } \\
\text { skab }\end{array}$} & \multicolumn{2}{|c|}{ Internationalisering } \\
\hline & $\begin{array}{l}\text { Stude- } \\
\text { rende }\end{array}$ & $\begin{array}{l}\text { Under- } \\
\text { viser }\end{array}$ & Andre & $\begin{array}{l}\text { Stude- } \\
\text { rende }\end{array}$ & $\begin{array}{l}\text { Under- } \\
\text { viser }\end{array}$ & & & & & & $\begin{array}{l}\text { Sprog- } \\
\text { politik }\end{array}$ & $\begin{array}{l}\text { Studen- } \\
\text { termobilitet }\end{array}$ \\
\hline $\begin{array}{l}\text { Jensen, C. \& Thøgersen, J. } \\
\text { (2011). Danish university } \\
\text { lecturers' attitudes towards } \\
\text { English as the medium of } \\
\text { instruction. I bérica, 22, 13-34. }\end{array}$ & & 1 & & & & & & & & & & \\
\hline $\begin{array}{l}\text { Jensen, C., Denver, L. et al. } \\
\text { (2013). Students' attitudes to } \\
\text { lecturers' English in English- } \\
\text { medium higher education in } \\
\text { Denmark, NJES (Online), 13(1), } \\
\text { 87-112. }\end{array}$ & 1 & & & & & & & & & & & \\
\hline
\end{tabular}




\begin{tabular}{|c|c|c|c|c|c|c|c|c|c|c|c|c|}
\hline \multirow[t]{2}{*}{ Titel } & \multicolumn{3}{|c|}{ Holdninger } & \multicolumn{2}{|c|}{ Oplevelse } & \multirow{2}{*}{$\begin{array}{l}\text { Lærings- } \\
\text { udbytte }\end{array}$} & \multirow{2}{*}{$\begin{array}{l}\text { Under- } \\
\text { visning } \\
\& \text { del- } \\
\text { tagelse }\end{array}$} & \multirow{2}{*}{$\begin{array}{l}\text { Problem- } \\
\text { er (fag vs. } \\
\text { sprog) }\end{array}$} & \multirow{2}{*}{$\begin{array}{l}\text { Sprog \& } \\
\text { identi- } \\
\text { tet }\end{array}$} & \multirow{2}{*}{$\begin{array}{l}\text { Sprog- } \\
\text { viden- } \\
\text { skab }\end{array}$} & \multicolumn{2}{|c|}{ Internationalisering } \\
\hline & $\begin{array}{l}\text { Stude- } \\
\text { rende }\end{array}$ & $\begin{array}{l}\text { Under- } \\
\text { viser }\end{array}$ & Andre & $\begin{array}{l}\text { Stude- } \\
\text { rende }\end{array}$ & $\begin{array}{l}\text { Under- } \\
\text { viser }\end{array}$ & & & & & & $\begin{array}{l}\text { Sprog- } \\
\text { politik }\end{array}$ & $\begin{array}{l}\text { Studen- } \\
\text { termobilitet }\end{array}$ \\
\hline $\begin{array}{l}\text { J ensen, C., Stæhr, L. S. \& } \\
\text { Thøgersen, J. (2009). Har ældre } \\
\text { universitetsundervisere flere } \\
\text { problemer med undervisning på } \\
\text { engelsk?. Sprogforum, } 46 .\end{array}$ & & & & & 1 & & & & & & & \\
\hline & & & & & & & & & & & & \\
\hline
\end{tabular}




\begin{tabular}{|c|c|c|c|c|c|c|c|c|c|c|c|c|}
\hline \multirow[t]{2}{*}{ Titel } & \multicolumn{3}{|c|}{ Holdninger } & \multicolumn{2}{|c|}{ Oplevelse } & \multirow{2}{*}{$\begin{array}{l}\text { Lærings- } \\
\text { udbytte }\end{array}$} & \multirow{2}{*}{$\begin{array}{l}\text { Under- } \\
\text { visning } \\
\& \text { del- } \\
\text { tagelse }\end{array}$} & \multirow{2}{*}{$\begin{array}{l}\text { Problem- } \\
\text { er (fag vs. } \\
\text { sprog) }\end{array}$} & \multirow{2}{*}{$\begin{array}{l}\text { Sprog \& } \\
\text { identi- } \\
\text { tet }\end{array}$} & \multirow{2}{*}{$\begin{array}{l}\text { Sprog- } \\
\text { viden- } \\
\text { skab }\end{array}$} & \multicolumn{2}{|c|}{ Interna-tionalisering } \\
\hline & $\begin{array}{l}\text { Stude- } \\
\text { rende }\end{array}$ & $\begin{array}{l}\text { Under- } \\
\text { viser }\end{array}$ & Andre & $\begin{array}{l}\text { Stude- } \\
\text { rende }\end{array}$ & $\begin{array}{l}\text { Under } \\
\text {-viser }\end{array}$ & & & & & & $\begin{array}{l}\text { Sprog- } \\
\text { politik }\end{array}$ & $\begin{array}{l}\text { Studen- } \\
\text { termobilitet }\end{array}$ \\
\hline $\begin{array}{l}\text { Kling, J. M. \& Stæhr, L. S. } \\
\text { (2011). Assessment and } \\
\text { assistance: Developing } \\
\text { university lecturers' language } \\
\text { skills through certification } \\
\text { feedback. I: R. Cancino, K. } \\
\text { Jæger \& L. Dam (red.): Policies, } \\
\text { Principles, Practices: New } \\
\text { Directions in Foreign Language } \\
\text { Education in the Era of } \\
\text { Educational Globalization, 213- } \\
\text { 245. Newcastle upon Tyne, UK: } \\
\text { Cambridge Scholars Press. }\end{array}$ & & & & & & & & 1 & & 1 & & \\
\hline
\end{tabular}




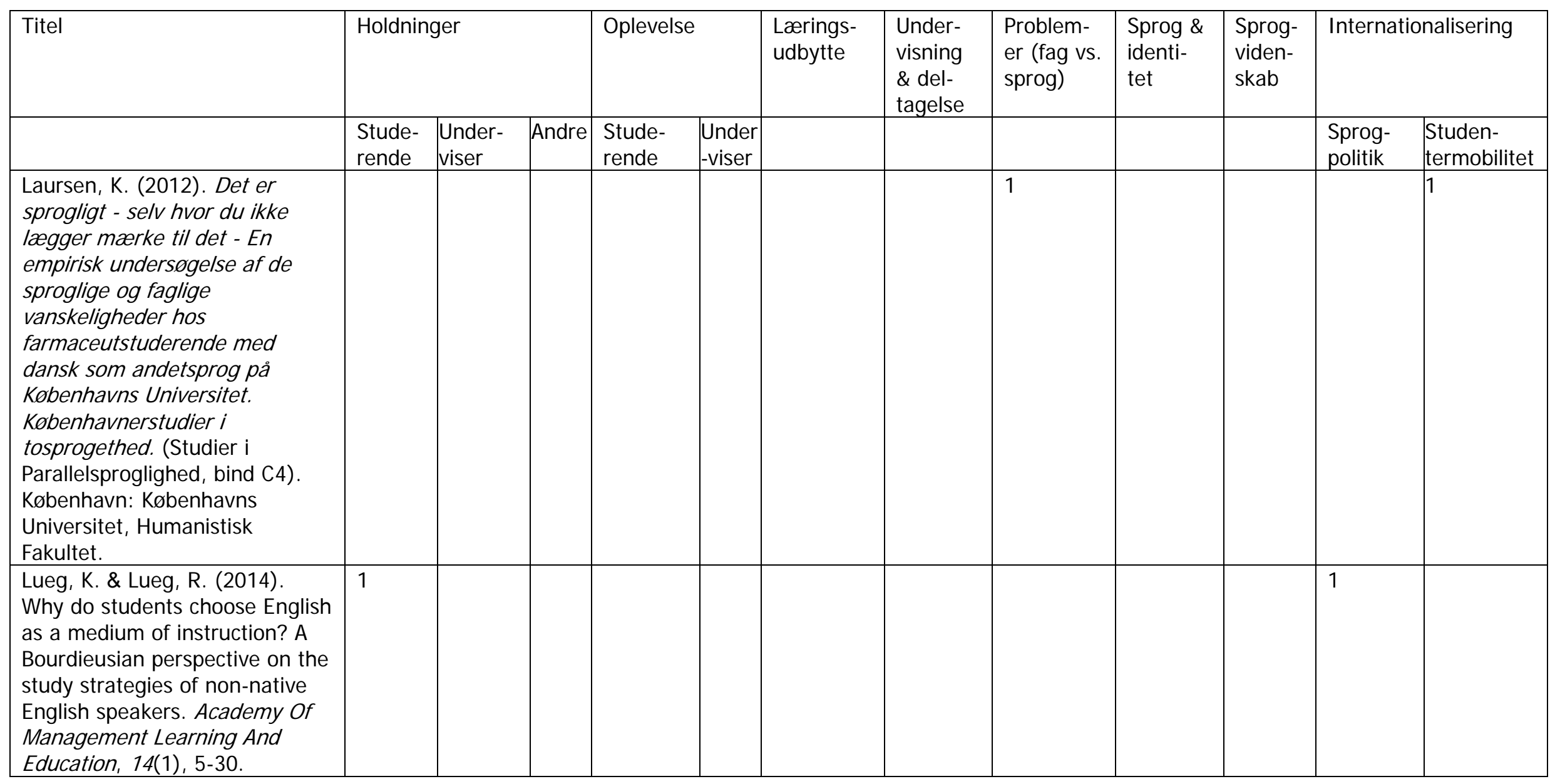




\begin{tabular}{|c|c|c|c|c|c|c|c|c|c|c|c|c|}
\hline \multirow[t]{2}{*}{ Titel } & \multicolumn{3}{|c|}{ Holdninger } & \multicolumn{2}{|c|}{ Oplevelse } & \multirow{2}{*}{$\begin{array}{l}\text { Lærings- } \\
\text { udbytte }\end{array}$} & \multirow{2}{*}{$\begin{array}{l}\text { Under- } \\
\text { visning } \\
\& \text { del- } \\
\text { tagelse }\end{array}$} & \multirow{2}{*}{$\begin{array}{l}\text { Problem- } \\
\text { er (fag } \\
\text { vs. sprog) }\end{array}$} & \multirow{2}{*}{$\begin{array}{l}\text { Sprog \& } \\
\text { identi- } \\
\text { tet }\end{array}$} & \multirow{2}{*}{$\begin{array}{l}\text { Sprog- } \\
\text { viden- } \\
\text { skab }\end{array}$} & \multicolumn{2}{|c|}{ Internationalisering } \\
\hline & $\begin{array}{l}\text { Stude- } \\
\text { rende }\end{array}$ & $\begin{array}{l}\text { Under- } \\
\text { viser }\end{array}$ & Andre & $\begin{array}{l}\text { Stude- } \\
\text { rende }\end{array}$ & $\begin{array}{l}\begin{array}{l}\text { Under } \\
\text {-viser }\end{array} \\
\end{array}$ & & & & & & $\begin{array}{l}\text { Sprog- } \\
\text { politik }\end{array}$ & $\begin{array}{l}\text { Studen- } \\
\text { termobi-litet }\end{array}$ \\
\hline $\begin{array}{l}\text { Lueg, K. \& Lueg, R. (2015). } \\
\text { English as a medium of } \\
\text { instruction at Sanish } \\
\text { universities: Status, } \\
\text { perspectives, and implications } \\
\text { for higher education executives. } \\
\text { Communication \& Language At } \\
\text { Work, 1(4), 53-73. }\end{array}$ & & & & & 1 & & & & & & 1 & \\
\hline $\begin{array}{l}\text { Madsen, M. (2008). Der vil altid } \\
\text { være brug for dansk. En } \\
\text { undersøgelse af } 11 \\
\text { naturvidenskabelige forskeres } \\
\text { grunde til at vælge henholdsvis } \\
\text { dansk og engelsk i deres } \\
\text { arbejde. (Købehavnerstudier i } \\
\text { tosprogethed, bind 48). } \\
\text { København: Københavns } \\
\text { Universitet, Det Humanistiske } \\
\text { Fakultet. }\end{array}$ & & 1 & 1 & & & & & & & & 1 & \\
\hline
\end{tabular}




\begin{tabular}{|c|c|c|c|c|c|c|c|c|c|c|c|c|}
\hline \multirow[t]{2}{*}{ Titel } & \multicolumn{3}{|c|}{ Holdninger } & \multicolumn{2}{|c|}{ Oplevelse } & \multirow{2}{*}{$\begin{array}{l}\text { Lærings- } \\
\text { udbytte }\end{array}$} & \multirow{2}{*}{$\begin{array}{l}\text { Under- } \\
\text { visning\& } \\
\text { del- } \\
\text { tagelse }\end{array}$} & \multirow{2}{*}{$\begin{array}{l}\text { Problem- } \\
\text { er (fag vs. } \\
\text { sprog) }\end{array}$} & \multirow{2}{*}{$\begin{array}{l}\text { Sprog\& } \\
\text { identi- } \\
\text { tet }\end{array}$} & \multirow{2}{*}{$\begin{array}{l}\text { Sprog- } \\
\text { viden- } \\
\text { skab }\end{array}$} & \multicolumn{2}{|c|}{ Internationalisering } \\
\hline & $\begin{array}{l}\text { Stude- } \\
\text { rende }\end{array}$ & $\begin{array}{l}\text { Under- } \\
\text { viser }\end{array}$ & Andre & $\begin{array}{l}\text { Stude- } \\
\text { rende }\end{array}$ & $\begin{array}{l}\text { Under- } \\
\text { viser }\end{array}$ & & & & & & $\begin{array}{l}\text { Sprog- } \\
\text { politik }\end{array}$ & $\begin{array}{l}\text { Studen- } \\
\text { termobilitet }\end{array}$ \\
\hline $\begin{array}{l}\text { Mortensen, J. \& Haberland, } \mathrm{H} \text {. } \\
\text { ( } 2012 \text { ). English - the new latin } \\
\text { of academia? Danish } \\
\text { universities as a case. } \\
\text { International Journal of the } \\
\text { Sociology of Language, 216, } \\
\text { 175-197. }\end{array}$ & & & & & & & & & & & 1 & \\
\hline $\begin{array}{l}\text { Mortensen, J. (2008). Circus } \\
\text { English? Investigating English } \\
\text { as an academic lingua franca at } \\
\text { BA study group meetings at } \\
\text { Roskilde University. I: H. } \\
\text { Haberland, J. Mortensen, A. } \\
\text { Fabricius,, B. Preisler, K. Risager } \\
\text { \& S. Kjærbeck (red.): Higher } \\
\text { Education in the Global Village: } \\
\text { Cultural and Linguistic Practices } \\
\text { in the International University. } \\
\text { Roskilde: Department of Culture } \\
\text { and Identity, Roskilde } \\
\text { Universitet, 85-96. }\end{array}$ & & & & & & & & & & 1 & & \\
\hline
\end{tabular}




\begin{tabular}{|c|c|c|c|c|c|c|c|c|c|c|c|c|}
\hline \multirow[t]{2}{*}{ Titel } & \multicolumn{3}{|c|}{ Holdninger } & \multicolumn{2}{|c|}{ Oplevelse } & \multirow{2}{*}{$\begin{array}{l}\text { Lærings- } \\
\text { udbytte }\end{array}$} & \multirow{2}{*}{$\begin{array}{l}\text { Under- } \\
\text { visning } \\
\& \text { del- } \\
\text { tagelse }\end{array}$} & \multirow{2}{*}{$\begin{array}{l}\text { Problem- } \\
\text { er (fag vs. } \\
\text { sprog) }\end{array}$} & \multirow{2}{*}{$\begin{array}{l}\text { Sprog \& } \\
\text { identi- } \\
\text { tet }\end{array}$} & \multirow{2}{*}{$\begin{array}{l}\text { Sprog- } \\
\text { viden- } \\
\text { skab }\end{array}$} & \multicolumn{2}{|c|}{ Internationalisering } \\
\hline & $\begin{array}{l}\text { Stude- } \\
\text { rende }\end{array}$ & $\begin{array}{l}\text { Under- } \\
\text { viser }\end{array}$ & Andre & $\begin{array}{l}\text { Stude- } \\
\text { rende }\end{array}$ & $\begin{array}{l}\text { Under } \\
\text {-viser }\end{array}$ & & & & & & $\begin{array}{l}\text { Sprog- } \\
\text { politik }\end{array}$ & \begin{tabular}{|l} 
Studen- \\
termobilitet
\end{tabular} \\
\hline $\begin{array}{l}\text { Nevile, M. \& Wagner, J. (2008). } \\
\text { Managing languages and } \\
\text { participation in a multilingual } \\
\text { group examination. I: H. } \\
\text { Haberland, J. Mortensen, A. } \\
\text { Fabricius, B. Preisler, K. Risager } \\
\text { \& S. Kjærbeck (red.): Higher } \\
\text { Education in the Global Village: } \\
\text { Cultural and Linguistic Practices } \\
\text { in the International University. } \\
\text { Roskilde: Department of Culture } \\
\text { and Identity, Roskilde } \\
\text { Universitet, 149-175. }\end{array}$ & & & & & & & & 1 & & & & \\
\hline
\end{tabular}




\begin{tabular}{|c|c|c|c|c|c|c|c|c|c|c|c|c|}
\hline \multirow[t]{2}{*}{ Titel } & \multicolumn{3}{|c|}{ Holdninger } & \multicolumn{2}{|c|}{ Oplevelse } & \multirow{2}{*}{$\begin{array}{l}\text { Lærings- } \\
\text { udbytte }\end{array}$} & \multirow{2}{*}{$\begin{array}{l}\text { Under- } \\
\text { visning } \\
\& \text { del- } \\
\text { tagelse }\end{array}$} & \multirow{2}{*}{$\begin{array}{l}\text { Problem- } \\
\text { er (fag vs. } \\
\text { sprog) }\end{array}$} & \multirow{2}{*}{$\begin{array}{l}\text { Sprog \& } \\
\text { identi- } \\
\text { tet }\end{array}$} & \multirow{2}{*}{$\begin{array}{l}\text { Sprog- } \\
\text { viden- } \\
\text { skab }\end{array}$} & \multicolumn{2}{|c|}{ Internationalisering } \\
\hline & $\begin{array}{l}\text { Stude- } \\
\text { rende }\end{array}$ & $\begin{array}{l}\text { Under- } \\
\text { viser }\end{array}$ & Andre & $\begin{array}{l}\text { Stude- } \\
\text { rende }\end{array}$ & $\begin{array}{l}\text { Under- } \\
\text { viser }\end{array}$ & & & & & & $\begin{array}{l}\text { Sprog- } \\
\text { politik }\end{array}$ & $\begin{array}{l}\text { Studen- } \\
\text { termobilitet }\end{array}$ \\
\hline $\begin{array}{l}\text { Odgaard, S. M. (2014). "Det er } \\
\text { ikke et sprog, man bare kan } \\
\text { samle op på gaden". En } \\
\text { undersøgelse af behovet for } \\
\text { kurser i akademisk dansk for } \\
\text { studerende med dansk som } \\
\text { andetsprog på Institut for } \\
\text { Tværkulturelle og Regionale } \\
\text { Studier på Københavns } \\
\text { Universitet. } \\
\text { (Københavnerstudier i } \\
\text { Tosprogethed: Studier i } \\
\text { Parallelsproglighed, bind C6). } \\
\text { København: Københavns } \\
\text { Universitet, Humanistisk } \\
\text { Fakultet. }\end{array}$ & & & & & & & & 1 & & & & \\
\hline
\end{tabular}




\begin{tabular}{|c|c|c|c|c|c|c|c|c|c|c|c|c|}
\hline \multirow[t]{2}{*}{ Titel } & \multicolumn{3}{|c|}{ Holdninger } & \multicolumn{2}{|c|}{ Oplevelse } & \multirow{2}{*}{$\begin{array}{l}\text { Lærings- } \\
\text { udbytte }\end{array}$} & \multirow{2}{*}{$\begin{array}{l}\text { Under- } \\
\text { visning } \\
\& \text { del- } \\
\text { tagelse }\end{array}$} & \multirow{2}{*}{$\begin{array}{l}\text { Problem- } \\
\text { er (fag vs. } \\
\text { sprog) }\end{array}$} & \multirow{2}{*}{$\begin{array}{l}\text { Sprog \& } \\
\text { identi- } \\
\text { tet }\end{array}$} & \multirow{2}{*}{$\begin{array}{l}\text { Sprog- } \\
\text { viden- } \\
\text { skab }\end{array}$} & \multicolumn{2}{|c|}{ Interna-tionalisering } \\
\hline & $\begin{array}{l}\text { Stude- } \\
\text { rende }\end{array}$ & $\begin{array}{l}\text { Under- } \\
\text { viser }\end{array}$ & Andre & \begin{tabular}{l|} 
Stude- \\
rende
\end{tabular} & $\begin{array}{l}\text { Under- } \\
\text { viser }\end{array}$ & & & & & & $\begin{array}{l}\text { Sprog- } \\
\text { politik }\end{array}$ & $\begin{array}{l}\text { Studen- } \\
\text { termobi-litet }\end{array}$ \\
\hline $\begin{array}{l}\text { Phillipson, R. \& T. Skutnabb- } \\
\text { Kangas (1999). "Englishisation: } \\
\text { One dimension of globalisation" } \\
\text { I: D. Graddol \& U. H. Meinhof } \\
\text { (red.): English in a Changing } \\
\text { World. Al L Review 13, 19-36. } \\
\text { Guilford: Al LA. }\end{array}$ & & & & & & & & & & & 1 & \\
\hline $\begin{array}{l}\text { Preisler, B. (2005). } \\
\text { Deconstructing "the domain of } \\
\text { science" as a sociolinguistic } \\
\text { entity in EFL societies: the } \\
\text { relationship between English } \\
\text { and Danish in higher education } \\
\text { and research. I: B. Preisler, A. } \\
\text { Fabricius, H. Haberland, S. } \\
\text { Kjærbeck \& K. Risager (red.): } \\
\text { The Consequences of Mobility: } \\
\text { Linguistic and Sociocultural } \\
\text { Contact Zones, 238-248. } \\
\text { Roskilde: RUC, Institut for } \\
\text { Sprog og Kultur. }\end{array}$ & & & & & & & & & & & 1 & \\
\hline $\begin{array}{l}\text { Preisler, B. (2008): Teaching in } \\
\text { a foreign language: linguistic } \\
\text { performance and academic } \\
\text { authority in the international } \\
\text { university. I: H. Haberland, J. } \\
\text { Mortensen, A. Fabricius, B. } \\
\text { Preisler, K. Risager \& S. } \\
\text { Kjærbeck (red.): Higher } \\
\text { Education in the Global Village. } \\
\text { Roskilde: Department of Culture } \\
\text { and Identity, Roskilde University }\end{array}$ & & & & & & & & 1 & 1 & & & \\
\hline
\end{tabular}




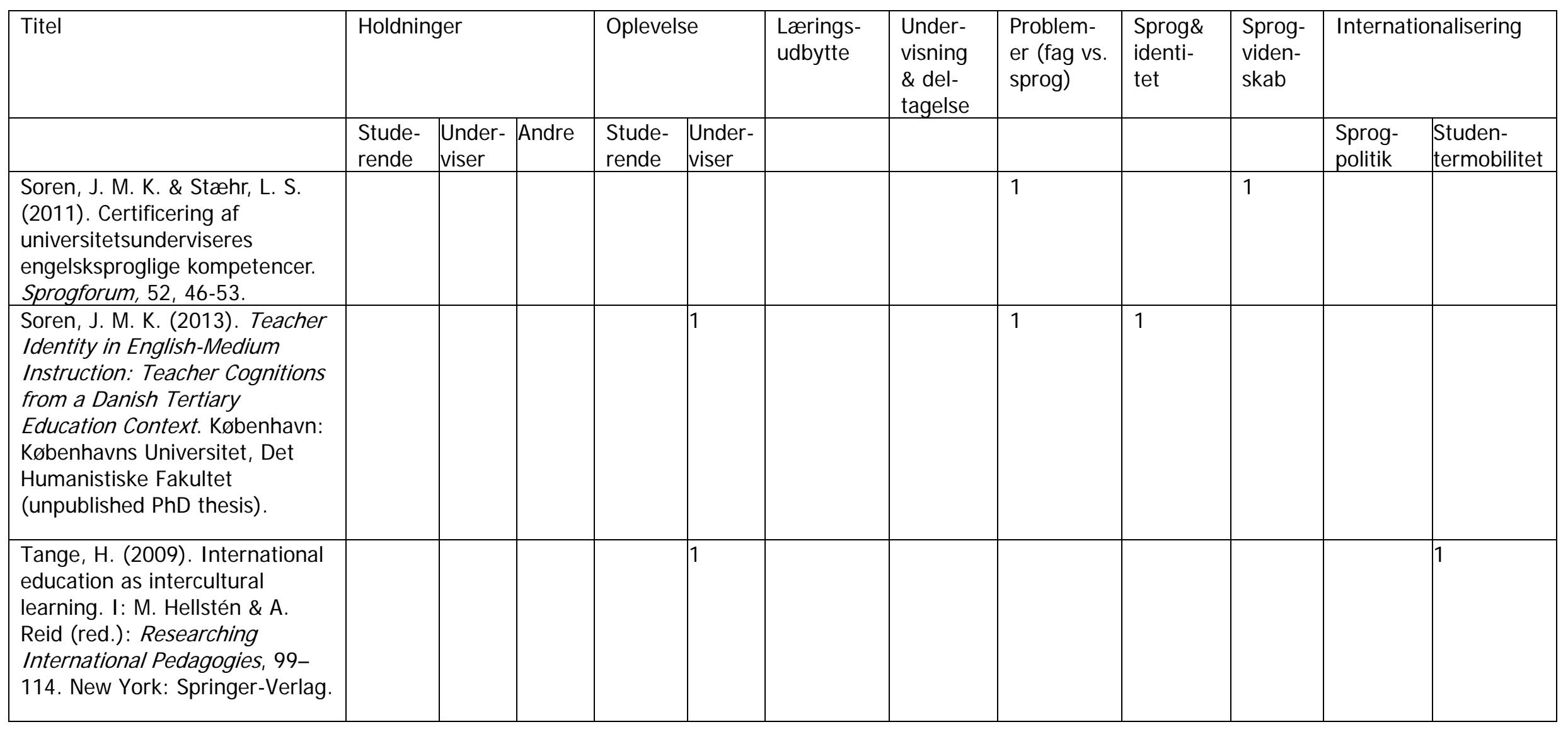




\begin{tabular}{|c|c|c|c|c|c|c|c|c|c|c|c|c|}
\hline \multirow[t]{2}{*}{ Titel } & \multicolumn{3}{|c|}{ Holdninger } & \multicolumn{2}{|c|}{ Oplevelse } & \multirow{2}{*}{$\begin{array}{l}\text { Lærings- } \\
\text { udbytte }\end{array}$} & \multirow{2}{*}{$\begin{array}{l}\text { Under- } \\
\text { visning } \\
\& \text { del- } \\
\text { tagelse }\end{array}$} & \multirow{2}{*}{$\begin{array}{l}\text { Problem- } \\
\text { er (fag vs. } \\
\text { sprog) }\end{array}$} & \multirow{2}{*}{$\begin{array}{l}\text { Sprog } \& \\
\text { identi- } \\
\text { tet }\end{array}$} & \multirow{2}{*}{$\begin{array}{l}\text { Sprog- } \\
\text { viden- } \\
\text { skab }\end{array}$} & \multicolumn{2}{|c|}{ Internationalisering } \\
\hline & $\begin{array}{l}\text { Stude- } \\
\text { rende }\end{array}$ & $\begin{array}{l}\text { Under- } \\
\text { viser }\end{array}$ & Andre & $\begin{array}{l}\text { Stude- } \\
\text { rende }\end{array}$ & $\begin{array}{l}\text { Under } \\
\text {-viser }\end{array}$ & & & & & & $\begin{array}{l}\text { Sprog- } \\
\text { politik }\end{array}$ & $\begin{array}{l}\text { Studen- } \\
\text { termobilitet }\end{array}$ \\
\hline $\begin{array}{l}\text { Tange, H. (2010). Underviser- } \\
\text { erfaringer med internationali- } \\
\text { sering. Aarhus: Aarhus School } \\
\text { of Business, University of } \\
\text { Aarhus, Department of } \\
\text { Language and Business } \\
\text { Communication. }\end{array}$ & & & & & 1 & & & & & & & \\
\hline $\begin{array}{l}\text { Tange, H. (2010). Caught in the } \\
\text { Tower of Babel: University } \\
\text { lecturers' experiences with } \\
\text { internationalization. Journal of } \\
\text { Language and International } \\
\text { Communication, 10, 137-49. }\end{array}$ & & & & & 1 & & 1 & 1 & & & & 1 \\
\hline $\begin{array}{l}\text { Thøgersen, J. (2013). Stylistic } \\
\text { and pedagogical consequences } \\
\text { of university teaching in English } \\
\text { in Europe. I: H. Haberland, D. } \\
\text { Lønsmann \& B. Preisler (red.), } \\
\text { Language Alternation, Language } \\
\text { Choice and Language Encounter } \\
\text { in International Tertiary } \\
\text { Education. Berlin: Springer. }\end{array}$ & & & & & & & 1 & & & & & \\
\hline
\end{tabular}




\begin{tabular}{|c|c|c|c|c|c|c|c|c|c|c|c|c|}
\hline Titel & Holdnir & ger & & Opleve & & Lærings- & & & & & Interna & onalisering \\
\hline & $\begin{array}{l}\text { Stude- } \\
\text { rende }\end{array}$ & $\begin{array}{l}\text { Under- } \\
\text { viser }\end{array}$ & Andre & $\begin{array}{l}\text { Stude- } \\
\text { rende }\end{array}$ & $\begin{array}{l}\text { Under- } \\
\text { viser }\end{array}$ & & & & & & $\begin{array}{l}\text { Sprog- } \\
\text { politik }\end{array}$ & \begin{tabular}{|l|} 
Studen- \\
termobilitet
\end{tabular} \\
\hline $\begin{array}{l}\text { Thøgersen, J. \& Airey, J. } \\
\text { (2011). Teaching } \\
\text { undergraduate science in } \\
\text { Danish and in English: A } \\
\text { comparison of speaking rate } \\
\text { and rhetorical style. English for } \\
\text { Specific Purposes, 30, 209-221. }\end{array}$ & & & & & & 1 & & & & & & \\
\hline $\begin{array}{l}\text { Thøgersen, J., J osephsson, O., } \\
\text { Londen, M. \& Salö, L. (2014). } \\
\text { Engelsk som } \\
\text { undervisningssprog på nordiske } \\
\text { universiteter - hvordan gør } \\
\text { man? I F. Gregersen (red.): } \\
\text { Hvor parallelt?: Om } \\
\text { parallelspråkighet på Nordens } \\
\text { universitet. TemaNord 2014. } \\
\text { København: Nordisk } \\
\text { Ministerråd, 55-123. }\end{array}$ & & & & & & & 1 & & & & 1 & \\
\hline $\begin{array}{l}\text { Vinther, J. \& Slethaug, G. } \\
\text { (2015). The impact of } \\
\text { international students on the } \\
\text { university work environment: A } \\
\text { comparative study of a } \\
\text { Canadian and a Danish } \\
\text { university. Language and } \\
\text { Intercultural Communication, } \\
\text { 15(1), 92-108. }\end{array}$ & & & & & & & & 1 & & & & 1 \\
\hline
\end{tabular}




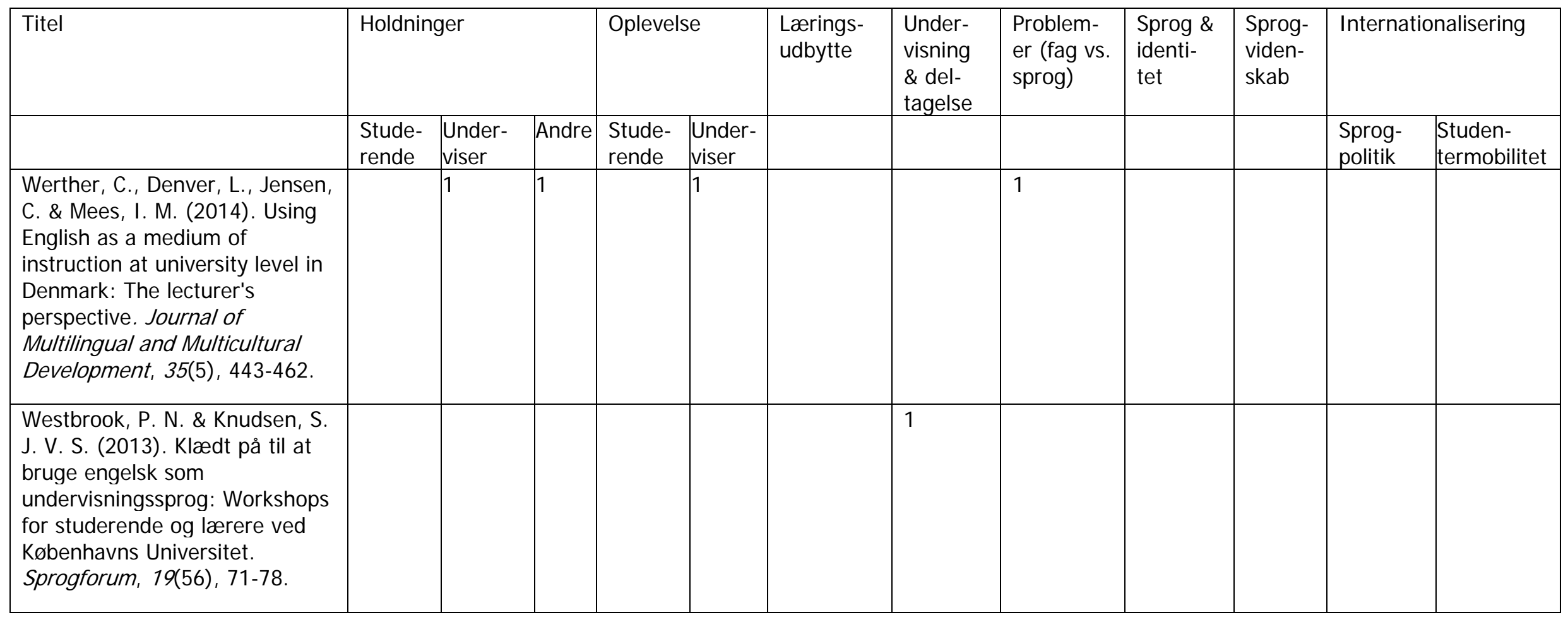




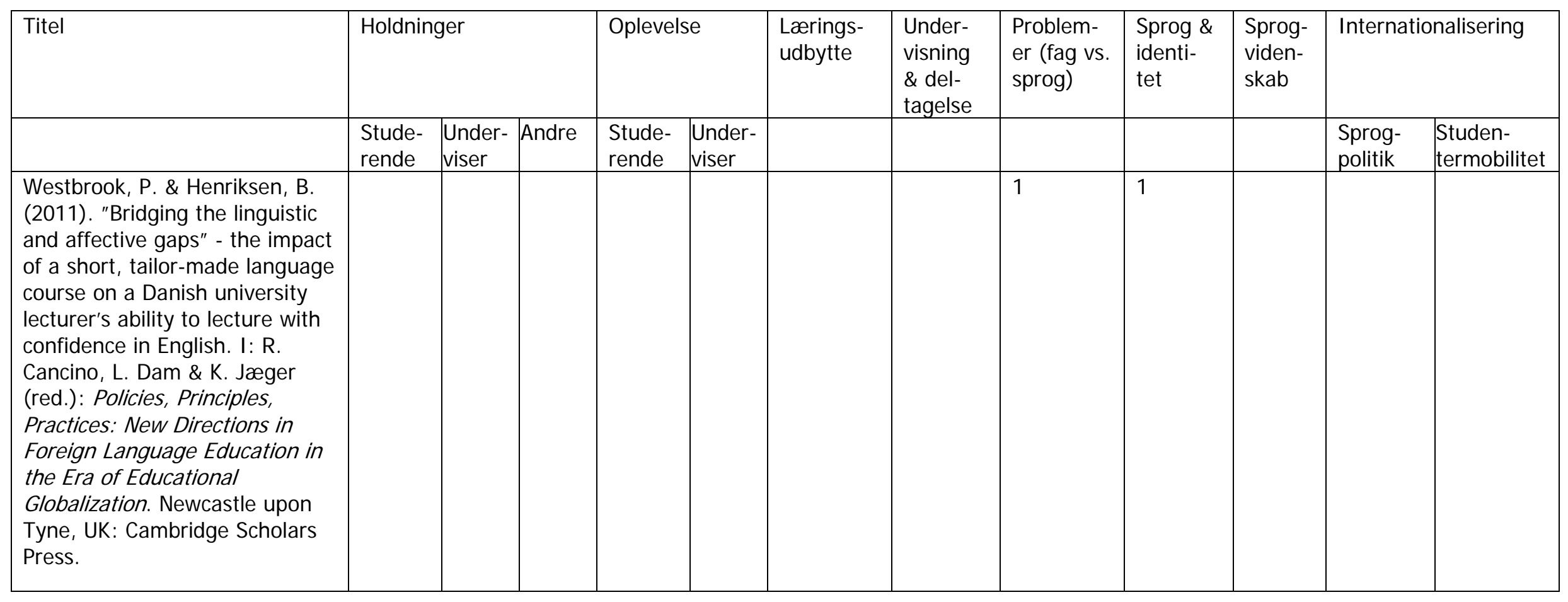


Appendix 2: Øvrig skandinavisk litteratur

\begin{tabular}{|c|c|c|c|c|c|c|c|c|c|c|c|c|}
\hline Titel & Holdnin & ger & & Oplevel & & Lærings- & Under- & Problem- & Sprog $\alpha$ & & Interna & tionalisering \\
\hline & $\begin{array}{l}\text { Stude- } \\
\text { rende }\end{array}$ & $\begin{array}{l}\text { Under- } \\
\text { viser }\end{array}$ & Andre & $\begin{array}{l}\text { Stude- } \\
\text { rende }\end{array}$ & $\begin{array}{l}\text { Under- } \\
\text { viser }\end{array}$ & & & & & & $\begin{array}{l}\text { Sprog- } \\
\text { politik }\end{array}$ & $\begin{array}{l}\text { Studen- } \\
\text { termobilitet }\end{array}$ \\
\hline $\begin{array}{l}\text { Airey, J. (2004). Can you teach } \\
\text { it in English? Aspects of the } \\
\text { language choice debate in } \\
\text { Swedish higher education. I: R. } \\
\text { Wilkinson (red.): Integrating } \\
\text { Content and Language: Meeting } \\
\text { the Challenge of a Multilingual } \\
\text { Higher Education, 97-108. } \\
\text { Maastricht, Netherlands: } \\
\text { Maastricht University Press. }\end{array}$ & & & & 1 & & & & & & & 1 & \\
\hline $\begin{array}{l}\text { Airey, J. (2009). Science, } \\
\text { Language and Literacy: Case } \\
\text { Studies of Learning in Swedish } \\
\text { University Physics. Uppsala, } \\
\text { Sweden: Acta Universitatis } \\
\text { Upsaliensis. (Unpublished PhD } \\
\text { thesis). }\end{array}$ & & & & & & 1 & & & & & & \\
\hline $\begin{array}{l}\text { Airey, J. (2010). "The ability of } \\
\text { students to explain science } \\
\text { concepts in two languages." } \\
\text { Hermes - Journal of Language } \\
\text { and Commmunication Studies, } \\
45,35-49 .\end{array}$ & & & & & & 1 & & 1 & & & & \\
\hline
\end{tabular}




\begin{tabular}{|c|c|c|c|c|c|c|c|c|c|c|c|c|}
\hline Titel & Holdnir & & & Oplevel & & Lærings- & Under- & & & Sprog- & Interna & tionalisering \\
\hline & $\begin{array}{l}\text { Stude- } \\
\text { rende }\end{array}$ & $\begin{array}{l}\text { Under- } \\
\text { viser }\end{array}$ & Andre & $\begin{array}{l}\text { Stude- } \\
\text { rende }\end{array}$ & $\begin{array}{l}\text { Under- } \\
\text { viser }\end{array}$ & & & & & & $\begin{array}{l}\text { Sprog- } \\
\text { politik }\end{array}$ & $\begin{array}{l}\text { Studentermo } \\
\text { bi-litet }\end{array}$ \\
\hline $\begin{array}{l}\text { Airey, J. (2011). The } \\
\text { relationship between teaching } \\
\text { language and student learning } \\
\text { in Swedish university physics. I: } \\
\text { B. Priesler, I. Klitgård \& A. H. } \\
\text { Fabricius (red.): Language and } \\
\text { Learning in the International } \\
\text { University: From English } \\
\text { Uniformity to Diversity and } \\
\text { Hybridity, 3-18. Bristol, UK: } \\
\text { Multilingual Matters. }\end{array}$ & & & & 1 & & & 1 & & & & & \\
\hline $\begin{array}{l}\text { Airey, J. (2011). Talking about } \\
\text { teaching in English: Swedish } \\
\text { university lecturers? } \\
\text { Experiences of changing } \\
\text { teaching language. Ibérica: } \\
\text { Revista de la Asociación } \\
\text { Europea de Lenguas para Fines } \\
\text { Específicos (AELFE), 22, 35-54. }\end{array}$ & & & & & 1 & & 1 & & & & & \\
\hline
\end{tabular}




\begin{tabular}{|c|c|c|c|c|c|c|c|c|c|c|c|c|}
\hline \multirow[t]{2}{*}{ Titel } & \multicolumn{3}{|c|}{ Holdninger } & \multicolumn{2}{|c|}{ Oplevelse } & \multirow{2}{*}{$\begin{array}{l}\text { Lærings- } \\
\text { udbytte }\end{array}$} & \multirow{2}{*}{$\begin{array}{l}\text { Under- } \\
\text { visning } \\
\& \text { del- } \\
\text { tagelse }\end{array}$} & \multirow{2}{*}{$\begin{array}{l}\text { Problemer } \\
\text { (fag vs. } \\
\text { sprog) }\end{array}$} & \multirow{2}{*}{$\begin{array}{l}\text { Sprog \& } \\
\text { identi- } \\
\text { tet }\end{array}$} & \multirow{2}{*}{$\begin{array}{l}\text { Sprog- } \\
\text { viden- } \\
\text { skab }\end{array}$} & \multicolumn{2}{|c|}{ Internationalisering } \\
\hline & $\begin{array}{l}\text { Stude- } \\
\text { rende }\end{array}$ & $\begin{array}{l}\text { Under- } \\
\text { viser }\end{array}$ & Andre & $\begin{array}{l}\text { Stude- } \\
\text { rende } \\
\end{array}$ & $\begin{array}{l}\text { Under- } \\
\text { viser }\end{array}$ & & & & & & $\begin{array}{l}\text { Sprog- } \\
\text { politik }\end{array}$ & $\begin{array}{l}\text { Studen- } \\
\text { termobilitet }\end{array}$ \\
\hline $\begin{array}{l}\text { Airey, J. (2012). "I Don't Teach } \\
\text { Language": The Linguistic } \\
\text { Attitudes of Physics Lecturers in } \\
\text { Sweden. AlLA Review, 25, 64- } \\
79 .\end{array}$ & & & & & 1 & & & & & & & \\
\hline $\begin{array}{l}\text { Airey, J. \& Linder, C. (2007). } \\
\text { Disciplinary learning in a second } \\
\text { language: A case study from } \\
\text { university physics. I: R. } \\
\text { Wilkinson \& V. Zegers (red.): } \\
\text { Researching Content and } \\
\text { Language Integration in Higher } \\
\text { Education. Maastricht: } \\
\text { Maastricht University Language } \\
\text { Centre, 161-171. }\end{array}$ & & & & 1 & & & & & & & & \\
\hline
\end{tabular}




\begin{tabular}{|c|c|c|c|c|c|c|c|c|c|c|c|c|}
\hline \multirow[t]{2}{*}{ Titel } & \multicolumn{3}{|c|}{ Holdninger } & \multicolumn{2}{|c|}{ Oplevelse } & \multirow{2}{*}{$\begin{array}{l}\text { Lærings- } \\
\text { udbytte }\end{array}$} & \multirow{2}{*}{$\begin{array}{l}\text { Under- } \\
\text { visning } \\
\& \text { del- } \\
\text { tagelse }\end{array}$} & \multirow{2}{*}{$\begin{array}{l}\text { Problemer } \\
\text { (fag vs. } \\
\text { sprog) }\end{array}$} & \multirow{2}{*}{$\begin{array}{l}\text { Sprog \& } \\
\text { identi- } \\
\text { tet }\end{array}$} & \multirow{2}{*}{$\begin{array}{l}\text { Sprog- } \\
\text { viden- } \\
\text { skab }\end{array}$} & \multicolumn{2}{|c|}{ Internationalisering } \\
\hline & $\begin{array}{l}\text { Stude- } \\
\text { rende }\end{array}$ & $\begin{array}{l}\text { Under- } \\
\text { viser }\end{array}$ & Andre & $\begin{array}{l}\text { Stude- } \\
\text { rende }\end{array}$ & $\begin{array}{l}\text { Under- } \\
\text { viser }\end{array}$ & & & & & & $\begin{array}{l}\text { Sprog- } \\
\text { politik }\end{array}$ & $\begin{array}{l}\text { Studen- } \\
\text { termobilitet }\end{array}$ \\
\hline $\begin{array}{l}\text { Airey, J. \& Linder, C. (2008). } \\
\text { Bilingual scientific literacy? The } \\
\text { use of English in Swedish } \\
\text { university science courses. } \\
\text { Nordic Journal of English } \\
\text { Studies, オ3), 145-161. }\end{array}$ & & & & & & & 1 & & & & & \\
\hline $\begin{array}{l}\text { Björkman , B. (2008)."So where } \\
\text { we are": Spoken lingua franca } \\
\text { English at a Swedish technical } \\
\text { university. English Today, 24(2), } \\
\text { 11-17. }\end{array}$ & & & & & & & & & & 1 & & \\
\hline $\begin{array}{l}\text { Björkman, B. (2010). Spoken } \\
\text { lingua franca English at a } \\
\text { Swedish technical university: An } \\
\text { investigation of form and } \\
\text { communicative effectiveness. } \\
\text { Stockholm: Stockholm } \\
\text { University. (Unpublished PhD } \\
\text { thesis) }\end{array}$ & & & & & & & & 1 & & 1 & & \\
\hline $\begin{array}{l}\text { Björkman, B. (2010). So you } \\
\text { think you can ELF: English as a } \\
\text { lingua franca as the medium of } \\
\text { instruction. Hermes: Journal of } \\
\text { Language and Communication } \\
\text { Studies, 45, 77-96. }\end{array}$ & & & & & & & 1 & & & 1 & & \\
\hline
\end{tabular}




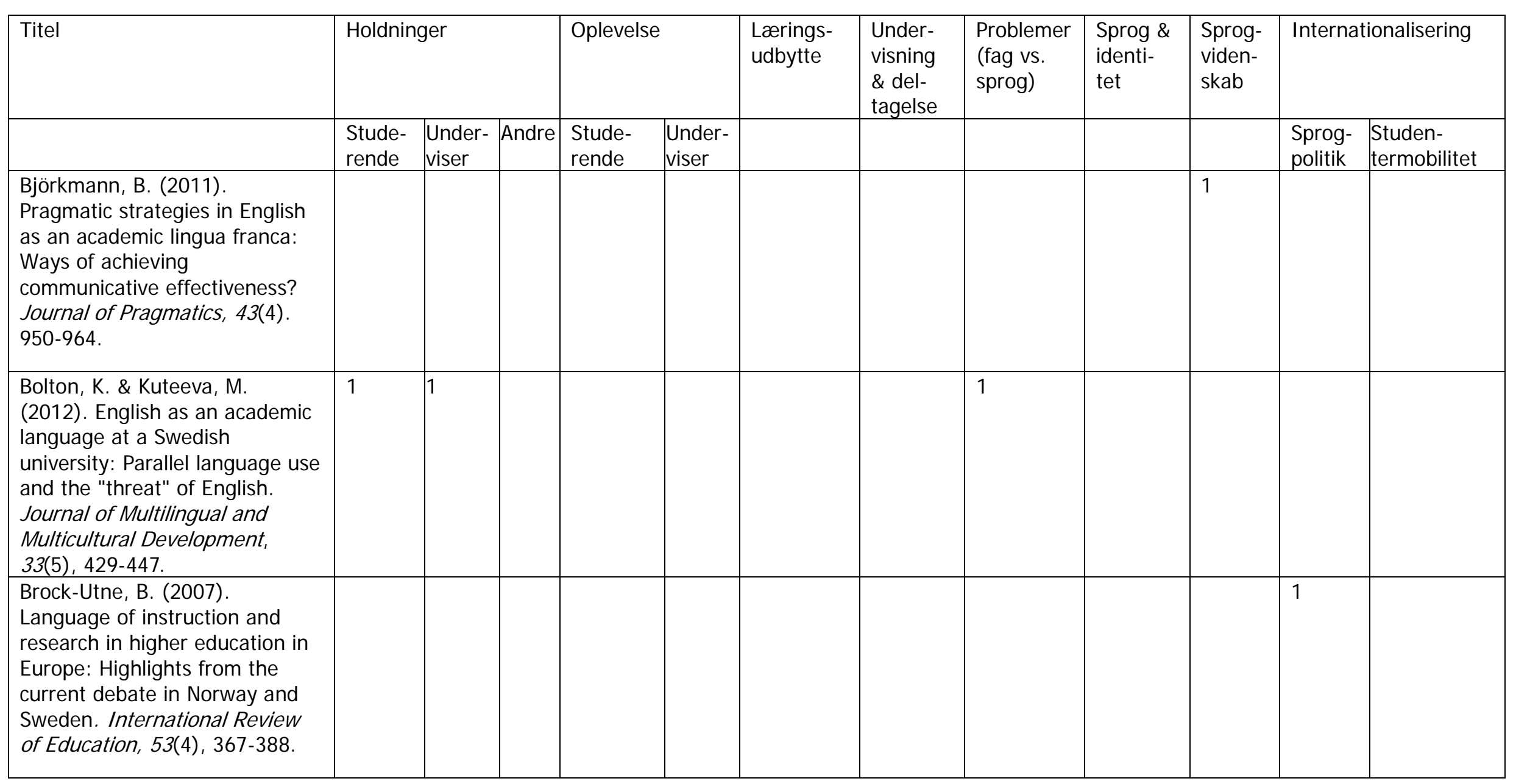




\begin{tabular}{|c|c|c|c|c|c|c|c|c|c|c|c|c|}
\hline Titel & Holdnin & & & Oplevel & & $\begin{array}{l}\text { Lærings- } \\
\text { udbytte }\end{array}$ & $\begin{array}{l}\text { Under- } \\
\text { visning }\end{array}$ & $\begin{array}{l}\text { Problemer } \\
\text { (fag vs. }\end{array}$ & $\begin{array}{l}\text { Sprog \& } \\
\text { identi- }\end{array}$ & $\begin{array}{l}\text { Sprog- } \\
\text { viden- }\end{array}$ & $\begin{array}{l}\text { Interna } \\
\text { tionalis }\end{array}$ & aring \\
\hline & $\begin{array}{l}\text { Stude- } \\
\text { rende }\end{array}$ & $\begin{array}{l}\text { Under- } \\
\text { viser }\end{array}$ & Andre & $\begin{array}{l}\text { Stude- } \\
\text { rende }\end{array}$ & $\begin{array}{l}\text { Under- } \\
\text { viser }\end{array}$ & & & & & & $\begin{array}{l}\text { Sprog- } \\
\text { politik }\end{array}$ & $\begin{array}{l}\text { Studen- } \\
\text { termobilitet }\end{array}$ \\
\hline $\begin{array}{l}\text { Gunnarsson, B.-L. \& Öhman, K. } \\
\text { (1997). Det internationaliserade } \\
\text { universitetet. En studie av } \\
\text { bruket av engelska och andra } \\
\text { främmande språk vid Uppsala } \\
\text { universitet. TeFa 16. Uppsala: } \\
\text { Uppsala Universitet, } \\
\text { Department of Scandinavian } \\
\text { Languages. }\end{array}$ & & & & & & & & & & & 1 & \\
\hline $\begin{array}{l}\text { Hellekjær, G. O. (2004). } \\
\text { Unprepared for English-medium } \\
\text { instruction: a critical look at } \\
\text { beginner students. I: R. } \\
\text { Wilkinson (red.): Integrating } \\
\text { Content and Language: Meeting } \\
\text { the Challenge of a Multilingual } \\
\text { Higher Education. Maastricht. } \\
\text { Universitaire pers Maastricht. }\end{array}$ & & & & & & & & 1 & & & & \\
\hline $\begin{array}{l}\text { Hellekjær, G. O. (2005): The } \\
\text { Acid Test: Does Upper } \\
\text { Secondary EFL Instruction } \\
\text { Effectively Prepare Norwegian } \\
\text { Students for the Reading of } \\
\text { English Textbooks at Colleges } \\
\text { and Universities? The University } \\
\text { of Oslo, The faculty of Arts, The } \\
\text { Department of Teacher } \\
\text { Education and School } \\
\text { Development. (Ph.d.- } \\
\text { afhandling). }\end{array}$ & & & & & & & & 1 & & & & \\
\hline
\end{tabular}


Academic English reading proficiency at the university level: A Norwegian case study. Reading in a Foreign Language, 21(2), 198-222.

\begin{tabular}{|c|c|c|c|c|c|c|c|c|c|c|c|c|}
\hline \multirow[t]{2}{*}{ Titel } & \multicolumn{3}{|c|}{ Holdninger } & \multicolumn{2}{|c|}{ Oplevelse } & \multirow{2}{*}{$\begin{array}{l}\text { Læ- } \\
\text { rings- } \\
\text { udbyt- } \\
\text { te }\end{array}$} & \multirow{2}{*}{$\begin{array}{l}\text { Under- } \\
\text { visning\& } \\
\text { del- } \\
\text { tagelse }\end{array}$} & \multirow{2}{*}{$\begin{array}{l}\text { Problemer } \\
\text { (fag vs. } \\
\text { sprog) }\end{array}$} & \multirow{2}{*}{$\begin{array}{l}\text { Sprog \& } \\
\text { identi- } \\
\text { tet }\end{array}$} & \multirow{2}{*}{$\begin{array}{l}\text { Sprog- } \\
\text { viden- } \\
\text { skab }\end{array}$} & \multicolumn{2}{|c|}{ Internationalisering } \\
\hline & $\begin{array}{l}\text { Stude- } \\
\text { rende }\end{array}$ & $\begin{array}{l}\text { Under- } \\
\text { viser }\end{array}$ & Andre & $\begin{array}{l}\text { Stude- } \\
\text { rende }\end{array}$ & $\begin{array}{l}\text { Under- } \\
\text { viser }\end{array}$ & & & & & & $\begin{array}{l}\text { Sprog- } \\
\text { politik }\end{array}$ & $\begin{array}{l}\text { Studen- } \\
\text { termobilitet }\end{array}$ \\
\hline $\begin{array}{l}\text { Hellekjær, G .O. (2010). } \\
\text { Language matters: Assessing } \\
\text { lecture comprehension in } \\
\text { Norwegian English-medium } \\
\text { higher education. I: C. Dalton- } \\
\text { Puffer, T. Nikula \& U. J. B. Smit } \\
\text { (red.): Language Use and } \\
\text { Language Learning in CLIL } \\
\text { Classrooms, 233-258. } \\
\text { Amsterdam: J ohn Benjamins. }\end{array}$ & & & & & & 1 & & 1 & & & & \\
\hline $\begin{array}{l}\text { Hellekjær, G. O. \& Westergaard, } \\
\text { M. R. (2002). An exploratory } \\
\text { survey of content learning } \\
\text { through English at Scandinavian } \\
\text { universities. I: A. M. Simensen } \\
\text { (red.): Teaching and Learning } \\
\text { Foreign Languages Issues and } \\
\text { IdeaS, 47-61. Oslo: Unipub. }\end{array}$ & & & & & & & & 1 & & & & \\
\hline $\begin{array}{l}\text { Hincks, R. (2010): Speaking } \\
\text { rate and information content in } \\
\text { English lingua franca oral } \\
\text { presentations. English for } \\
\text { Specific Purposes, } 29(1), 4-18 .\end{array}$ & & & & & & & & 1 & & 1 & & \\
\hline
\end{tabular}




\begin{tabular}{|c|c|c|c|c|c|c|c|c|c|c|c|c|}
\hline \multirow[t]{2}{*}{ Titel } & \multicolumn{3}{|c|}{ Holdninger } & \multicolumn{2}{|c|}{ Oplevelse } & \multirow{2}{*}{$\begin{array}{l}\text { Lærings- } \\
\text { udbytte }\end{array}$} & \multirow{2}{*}{$\begin{array}{l}\text { Under- } \\
\text { visning } \\
\& \text { del- } \\
\text { tagelse }\end{array}$} & \multirow{2}{*}{$\begin{array}{l}\text { Problemer } \\
\text { (fag vs. } \\
\text { sprog) }\end{array}$} & \multirow{2}{*}{$\begin{array}{l}\text { Sprog \& } \\
\text { identi- } \\
\text { tet }\end{array}$} & \multirow{2}{*}{$\begin{array}{l}\text { Sprog- } \\
\text { viden- } \\
\text { skab }\end{array}$} & \multicolumn{2}{|c|}{ Internationalisering } \\
\hline & $\begin{array}{l}\text { Stude- } \\
\text { rende }\end{array}$ & $\begin{array}{l}\text { Under- } \\
\text { viser }\end{array}$ & Andre & $\begin{array}{l}\text { Stude- } \\
\text { rende }\end{array}$ & $\begin{array}{l}\text { Under- } \\
\text { viser }\end{array}$ & & & & & & $\begin{array}{l}\text { Sprog- } \\
\text { politik }\end{array}$ & \begin{tabular}{|l|} 
Studen- \\
termobilitet
\end{tabular} \\
\hline $\begin{array}{l}\text { Höglin, R. (2002). Engelska } \\
\text { språket som hot och tillgång i } \\
\text { Norden. Köpenhamn: Nordiska } \\
\text { Ministerrådet. }\end{array}$ & & & & & & & & & & & 1 & \\
\hline $\begin{array}{l}\text { Hyltenstam, K. (2004). } \\
\text { Engelskan, skolans } \\
\text { språkundervisning och svensk } \\
\text { språkpolitik. I: O. J osephson \& } \\
\text { B. Lindgren (red.): Engelskan i } \\
\text { Sverige. Språkval i utbildning, } \\
\text { arbete och kulturliv, 36-110. } \\
\text { Stockholm: Svenska } \\
\text { Språknämnden. }\end{array}$ & & & & & & & & & & & 1 & \\
\hline $\begin{array}{l}\text { Kuteeva, M. \& Airey, J. (2012). } \\
\text { Disciplinary differences in } \\
\text { knowledge structures and their } \\
\text { impact on the use of English in } \\
\text { Swedish higher education. } \\
\text { Higher Education, } 6 \pi 5), 533 \text { - } \\
549 .\end{array}$ & & & & & & & & & & & 1 & \\
\hline
\end{tabular}




\begin{tabular}{|c|c|c|c|c|c|c|c|c|c|c|c|c|}
\hline \multirow[t]{2}{*}{ Titel } & \multicolumn{3}{|c|}{ Holdninger } & \multicolumn{2}{|c|}{ Oplevelse } & \multirow{2}{*}{$\begin{array}{l}\text { Lærings- } \\
\text { udbytte }\end{array}$} & \multirow{2}{*}{$\begin{array}{l}\text { Under- } \\
\text { visning } \\
\& \text { del- } \\
\text { tagelse }\end{array}$} & \multirow{2}{*}{$\begin{array}{l}\text { Problemer } \\
\text { (fag vs. } \\
\text { sprog) }\end{array}$} & \multirow{2}{*}{$\begin{array}{l}\text { Sprog \& } \\
\text { identi- } \\
\text { tet }\end{array}$} & \multirow{2}{*}{$\begin{array}{l}\text { Sprog- } \\
\text { viden- } \\
\text { skab }\end{array}$} & \multicolumn{2}{|c|}{ Internationalisering } \\
\hline & $\begin{array}{l}\text { Stude- } \\
\text { rende }\end{array}$ & $\begin{array}{l}\text { Under- } \\
\text { viser }\end{array}$ & Andre & $\begin{array}{l}\text { Stude- } \\
\text { rende }\end{array}$ & $\begin{array}{l}\text { Under- } \\
\text { viser }\end{array}$ & & & & & & $\begin{array}{l}\text { Sprog- } \\
\text { politik }\end{array}$ & $\begin{array}{l}\text { Studen- } \\
\text { termobilitet }\end{array}$ \\
\hline $\begin{array}{l}\text { Kuteeva, M. (2014). The parallel } \\
\text { language use of Swedish and } \\
\text { English: The question of } \\
\text { "nativeness" in university } \\
\text { policies and practices. Journal } \\
\text { of Multilingual and Multicultural } \\
\text { Development, 35(4), 332-344. }\end{array}$ & 1 & & & & & & & & & & 1 & \\
\hline $\begin{array}{l}\text { Kuteeva, M. \& Airey, J. (2014). } \\
\text { Disciplinary differences in the } \\
\text { use of English in higher } \\
\text { education: Reflections on recent } \\
\text { Language policy developments. } \\
\text { Higher Education: The } \\
\text { International Journal of Higher } \\
\text { Education and Educational } \\
\text { Planning, 6オ5), 533-549. }\end{array}$ & & & & & & & & & & & 1 & \\
\hline
\end{tabular}




\begin{tabular}{|c|c|c|c|c|c|c|c|c|c|c|c|c|}
\hline \multirow[t]{2}{*}{ Titel } & \multicolumn{3}{|c|}{ Holdninger } & \multicolumn{2}{|c|}{ Oplevelse } & \multirow{2}{*}{$\begin{array}{l}\text { Lærings } \\
\text {-udbytte }\end{array}$} & \multirow{2}{*}{$\begin{array}{l}\text { Under- } \\
\text { visning } \\
\& \text { del- } \\
\text { tagelse }\end{array}$} & \multirow{2}{*}{$\begin{array}{l}\text { Problemer } \\
\text { (fag vs. } \\
\text { sprog) }\end{array}$} & \multirow{2}{*}{$\begin{array}{l}\text { Sprog \& } \\
\text { identi- } \\
\text { tet }\end{array}$} & \multirow{2}{*}{$\begin{array}{l}\text { Sprog- } \\
\text { viden- } \\
\text { skab }\end{array}$} & \multicolumn{2}{|c|}{ Internationalisering } \\
\hline & $\begin{array}{l}\text { Stude- } \\
\text { rende }\end{array}$ & $\begin{array}{l}\text { Under- } \\
\text { viser }\end{array}$ & Andre & $\begin{array}{l}\text { Stude- } \\
\text { rende }\end{array}$ & $\begin{array}{l}\text { Under- } \\
\text { viser }\end{array}$ & & & & & & $\begin{array}{l}\text { Sprog- } \\
\text { politik }\end{array}$ & $\begin{array}{l}\text { Studen- } \\
\text { termobilitet }\end{array}$ \\
\hline $\begin{array}{l}\text { Ljosland, R. (2008). Lingua } \\
\text { franca, prestisjespräk og } \\
\text { forestilt fellesskap: Om engelsk } \\
\text { som akademisk spräk i Norge: } \\
\text { Et kasusstudium i bred } \\
\text { kontekst. Oslo: Norwegian } \\
\text { University of Science and } \\
\text { Technology. (PhD thesis). }\end{array}$ & 1 & 1 & 1 & 1 & 1 & & & & & 1 & 1 & \\
\hline $\begin{array}{l}\text { Ljosland, R. (2010). Teaching } \\
\text { through English: Monolingual } \\
\text { policy meets multilingual } \\
\text { practice. Hermes, 45, 99-113. }\end{array}$ & & & & & & & & & & 1 & 1 & \\
\hline
\end{tabular}




\begin{tabular}{|c|c|c|c|c|c|c|c|c|c|c|c|c|}
\hline \multirow[t]{2}{*}{ Titel } & \multicolumn{3}{|c|}{ Holdninger } & \multicolumn{2}{|c|}{ Oplevelse } & \multirow{2}{*}{$\begin{array}{l}\text { Lærings- } \\
\text { udbytte }\end{array}$} & \multirow{2}{*}{$\begin{array}{l}\text { Under- } \\
\text { visning } \\
\& \text { del- } \\
\text { tagelse }\end{array}$} & \multirow{2}{*}{$\begin{array}{l}\text { Problemer } \\
\text { (fag vs. } \\
\text { sprog) }\end{array}$} & \multirow{2}{*}{$\begin{array}{l}\text { Sprog \& } \\
\text { identi- } \\
\text { tet }\end{array}$} & \multirow{2}{*}{$\begin{array}{l}\text { Sprog- } \\
\text { viden- } \\
\text { skab }\end{array}$} & \multicolumn{2}{|c|}{ Internationalisering } \\
\hline & $\begin{array}{l}\text { Stude- } \\
\text { rende }\end{array}$ & $\begin{array}{l}\text { Under- } \\
\text { viser }\end{array}$ & Andre & $\begin{array}{l}\text { Stude- } \\
\text { rende }\end{array}$ & $\begin{array}{l}\text { Under- } \\
\text { viser }\end{array}$ & & & & & & $\begin{array}{l}\text { Sprog- } \\
\text { politik }\end{array}$ & $\begin{array}{l}\text { Studen- } \\
\text { termobilitet }\end{array}$ \\
\hline $\begin{array}{l}\text { Ljosland, R. (2014). Language } \\
\text { planning confronted by } \\
\text { everyday communication in the } \\
\text { international university: The } \\
\text { Norwegian case. Journal of } \\
\text { Multilingual and Multicultural } \\
\text { Development, 35(4), 392-405. }\end{array}$ & & & & & & & & & & 1 & 1 & \\
\hline $\begin{array}{l}\text { Nilsson, B. (2003). } \\
\text { Internationalization at home } \\
\text { from a Swedish perspective: } \\
\text { The case of Malmö. Journal of } \\
\text { Studies in International } \\
\text { education, } \pi 1), 27-40 \text {. }\end{array}$ & & & & & & & & & & & 1 & \\
\hline
\end{tabular}




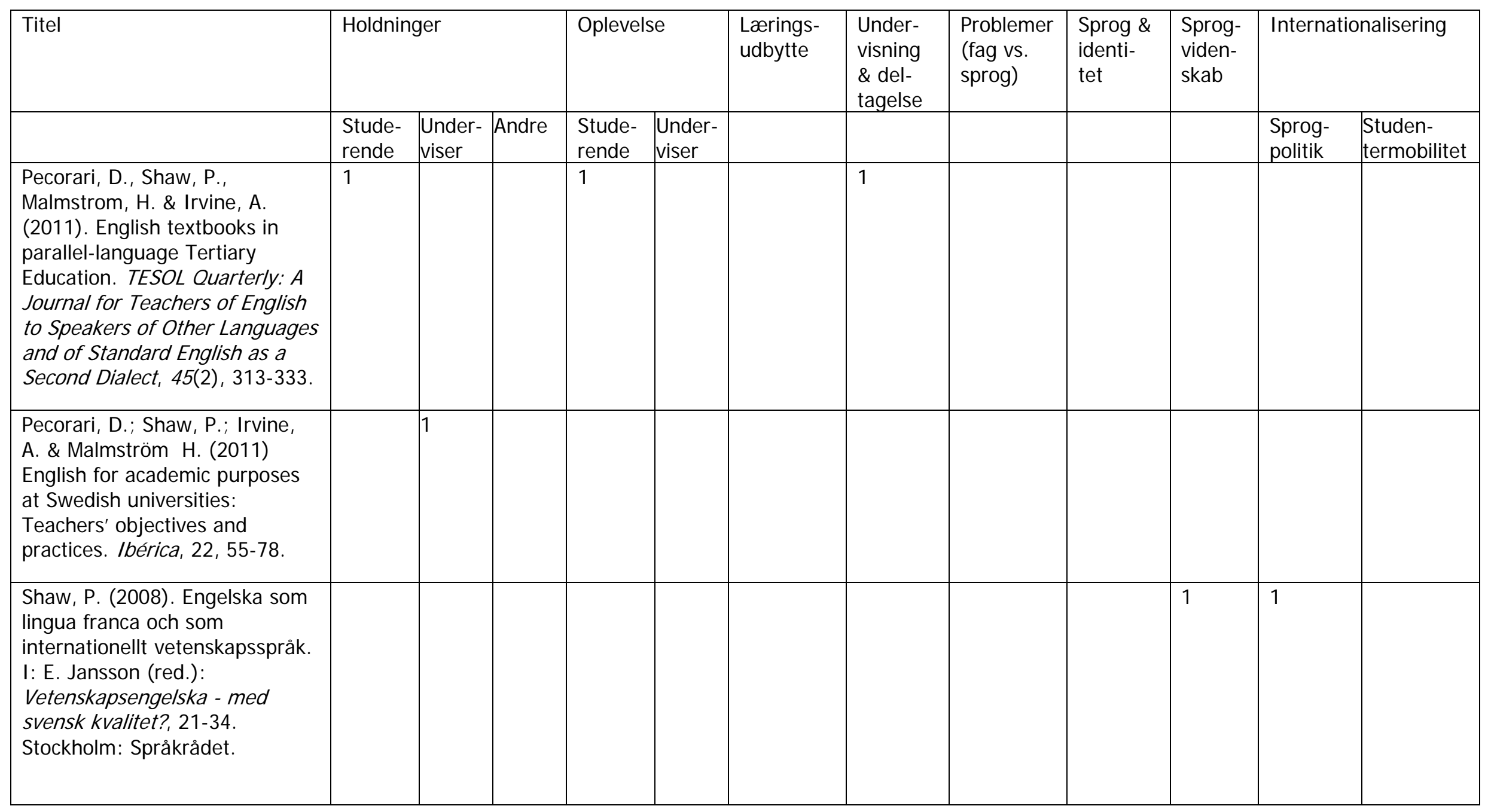




\begin{tabular}{|c|c|c|c|c|c|c|c|c|c|c|c|c|}
\hline \multirow[t]{2}{*}{ Titel } & \multicolumn{3}{|c|}{ Holdninger } & \multicolumn{2}{|c|}{ Oplevelse } & \multirow{2}{*}{$\begin{array}{l}\text { Lærings } \\
\text {-udbytte }\end{array}$} & \multirow{2}{*}{$\begin{array}{l}\text { Under- } \\
\text { visning } \\
\& \text { del- } \\
\text { tagelse }\end{array}$} & \multirow{2}{*}{$\begin{array}{l}\text { Problemer } \\
\text { (fag vs. } \\
\text { sprog) }\end{array}$} & \multirow{2}{*}{$\begin{array}{l}\text { Sprog \& } \\
\text { identi- } \\
\text { tet }\end{array}$} & \multirow{2}{*}{$\begin{array}{l}\text { Sprog- } \\
\text { viden- } \\
\text { skab }\end{array}$} & \multicolumn{2}{|c|}{ Internationalisering } \\
\hline & $\begin{array}{l}\text { Stude- } \\
\text { rende }\end{array}$ & $\begin{array}{l}\text { Under- } \\
\text { viser }\end{array}$ & Andre & $\begin{array}{l}\text { Stude- } \\
\text { rende }\end{array}$ & $\begin{array}{l}\text { Under- } \\
\text { viser }\end{array}$ & & & & & & $\begin{array}{l}\text { Sprog- } \\
\text { politik }\end{array}$ & $\begin{array}{l}\text { Studenter- } \\
\text { mobilitet }\end{array}$ \\
\hline $\begin{array}{l}\text { Söderlundh, H. (2010). } \\
\text { Internationella universitet- } \\
\text { lokala sprakval. Om bruket av } \\
\text { talad svenska i engelsksprakiga } \\
\text { kursmiljöer. Uppsala: Uppsala } \\
\text { Universitet. }\end{array}$ & 1 & 1 & & & & & & & & 1 & & \\
\hline $\begin{array}{l}\text { Söderlundh, H. (2012). Global } \\
\text { policies and local norms: } \\
\text { Sociolinguistic awareness and } \\
\text { language choice at an } \\
\text { international university. } \\
\text { International Journal of the } \\
\text { Sociology of Language, 216, 87- } \\
109 \text {. }\end{array}$ & & & & & & & & & & & 1 & \\
\hline
\end{tabular}




\begin{tabular}{|c|c|c|c|c|c|c|c|c|c|c|c|c|}
\hline \multirow[t]{2}{*}{ Titel } & \multicolumn{3}{|c|}{ Holdninger } & \multicolumn{2}{|c|}{ Oplevelse } & \multirow{2}{*}{$\begin{array}{l}\text { Lærings } \\
\text {-udbytte }\end{array}$} & \multirow{2}{*}{$\begin{array}{l}\text { Under- } \\
\text { visning } \\
\& \text { del- } \\
\text { tagelse } \\
\end{array}$} & \multirow{2}{*}{$\begin{array}{l}\text { Problemer } \\
\text { (fag vs. } \\
\text { sprog) }\end{array}$} & \multirow{2}{*}{$\begin{array}{l}\text { Sprog \& } \\
\text { identi- } \\
\text { tet }\end{array}$} & \multirow{2}{*}{$\begin{array}{l}\text { Sprog- } \\
\text { viden- } \\
\text { skab }\end{array}$} & \multicolumn{2}{|c|}{ Internationalisering } \\
\hline & $\begin{array}{l}\text { Stude- } \\
\text { rende }\end{array}$ & $\begin{array}{l}\text { Under- } \\
\text { viser }\end{array}$ & Andre & $\begin{array}{l}\text { Stude- } \\
\text { rende }\end{array}$ & $\begin{array}{l}\text { Under- } \\
\text { viser }\end{array}$ & & & & & & $\begin{array}{l}\text { Sprog- } \\
\text { politik }\end{array}$ & $\begin{array}{l}\text { Studen- } \\
\text { termobilitet }\end{array}$ \\
\hline $\begin{array}{l}\text { Söderlundh, H. (2008). } \\
\text { Language practices in Swedish } \\
\text { higher education: Results from } \\
\text { a pilot study. I: H. Haberland, J. } \\
\text { Mortensen, A. Fabricius, B. } \\
\text { Preisler, K. Risager \& S. } \\
\text { Kjærbeck (red.): Higher } \\
\text { Education in the Global Village, } \\
\text { 97-102. Roskilde: Roskilde } \\
\text { University, Department of } \\
\text { Culture and Identity. }\end{array}$ & & & & & & & & & & 1 & & \\
\hline $\begin{array}{l}\text { Östman, L. (1998). How } \\
\text { companion meanings are } \\
\text { expressed by science education } \\
\text { discourse. I: D. Roberts \& L. } \\
\text { Östman (red.): Problems of } \\
\text { Meaning in Science Education, } \\
\text { 54-70. New York: Teachers } \\
\text { College Press. }\end{array}$ & & & & & & & & & & & & \\
\hline
\end{tabular}




\section{Appendix 3: I nternational litteratur}

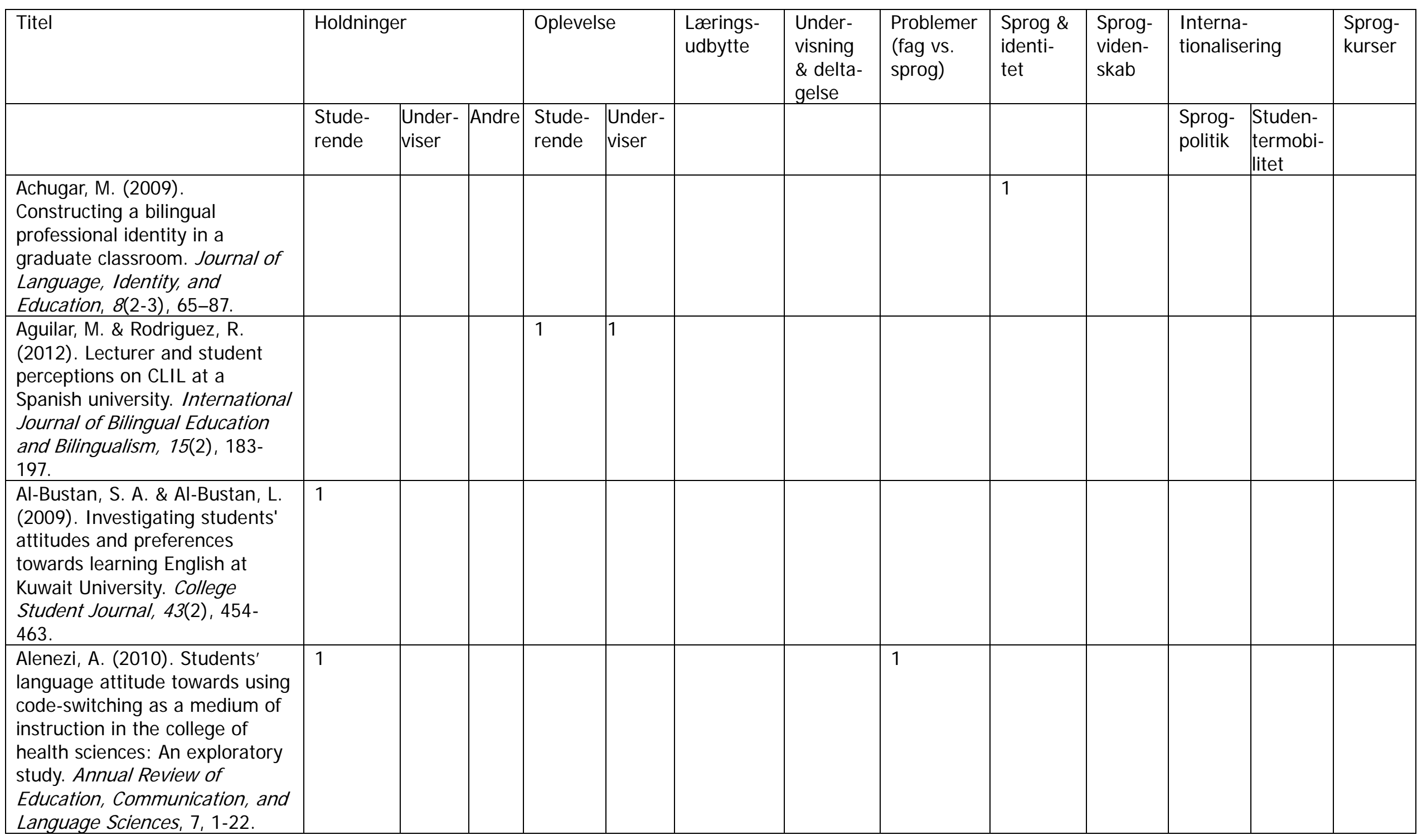




\begin{tabular}{|c|c|c|c|c|c|c|c|c|c|c|c|c|c|}
\hline \multirow[t]{2}{*}{ Titel } & \multicolumn{3}{|c|}{ Holdninger } & \multicolumn{2}{|c|}{ Oplevelse } & \multirow[t]{2}{*}{$\begin{array}{l}\text { Lærings- } \\
\text { udbytte }\end{array}$} & \multirow{2}{*}{$\begin{array}{l}\text { Under- } \\
\text { visning } \\
\& \text { delta- } \\
\text { gelse }\end{array}$} & \multirow{2}{*}{$\begin{array}{l}\text { Problem- } \\
\text { er (fag vs. } \\
\text { sprog) }\end{array}$} & \multirow{2}{*}{$\begin{array}{l}\text { Sprog\& } \\
\text { identi- } \\
\text { tet }\end{array}$} & \multirow{2}{*}{$\begin{array}{l}\text { Sprog- } \\
\text { viden- } \\
\text { skab }\end{array}$} & \multicolumn{2}{|c|}{$\begin{array}{l}\text { Interna- } \\
\text { tionalisering }\end{array}$} & \multirow[t]{2}{*}{$\begin{array}{l}\text { Sprog- } \\
\text { kurser }\end{array}$} \\
\hline & $\begin{array}{l}\text { Stude- } \\
\text { rende }\end{array}$ & $\begin{array}{l}\text { Under- } \\
\text { viser }\end{array}$ & Andre & $\begin{array}{l}\text { Stude- } \\
\text { rende }\end{array}$ & $\begin{array}{l}\text { Under- } \\
\text { viser }\end{array}$ & & & & & & $\begin{array}{l}\text { Sprog- } \\
\text { politik }\end{array}$ & $\begin{array}{l}\text { Studen- } \\
\text { termobi- } \\
\text { litet }\end{array}$ & \\
\hline $\begin{array}{l}\text { Altbach, P. G. \& Knight, J. } \\
\text { (2007). The internationalization } \\
\text { of higher education: Motivations } \\
\text { and realities. Journal of Studies } \\
\text { in International Education, } \\
\text { 11(3-4), 290-305. }\end{array}$ & & & & & & & & & & & 1 & & \\
\hline $\begin{array}{l}\text { Andersson, I. \& Rusanganwa, J. } \\
\text { (2011). Language and space in } \\
\text { a multilingual undergraduate } \\
\text { physics classroom in Rwanda. } \\
\text { International Journal of Bilingual } \\
\text { Education and Bilingualism, } \\
\text { 14(6), 751-764. }\end{array}$ & & & & & & & & 1 & 1 & 1 & & & \\
\hline $\begin{array}{l}\text { Andrade, M. S. (2007). } \\
\text { Addressing the linguistic needs } \\
\text { of nonnative English speakers in } \\
\text { the first year. Journal of The } \\
\text { First-Year Experience \& } \\
\text { Students in Transition, 192), } \\
69-86 .\end{array}$ & & & & & & & & 1 & & & & & 1 \\
\hline
\end{tabular}

\begin{tabular}{|l|l|l|l|l|l|l|l|l|l|l|l|}
\hline Titel & Holdninger & Oplevelse & Lærings- & Under- & Problem- & Sprog\& & Sprog- & Interna- & Sprog- \\
\hline
\end{tabular}




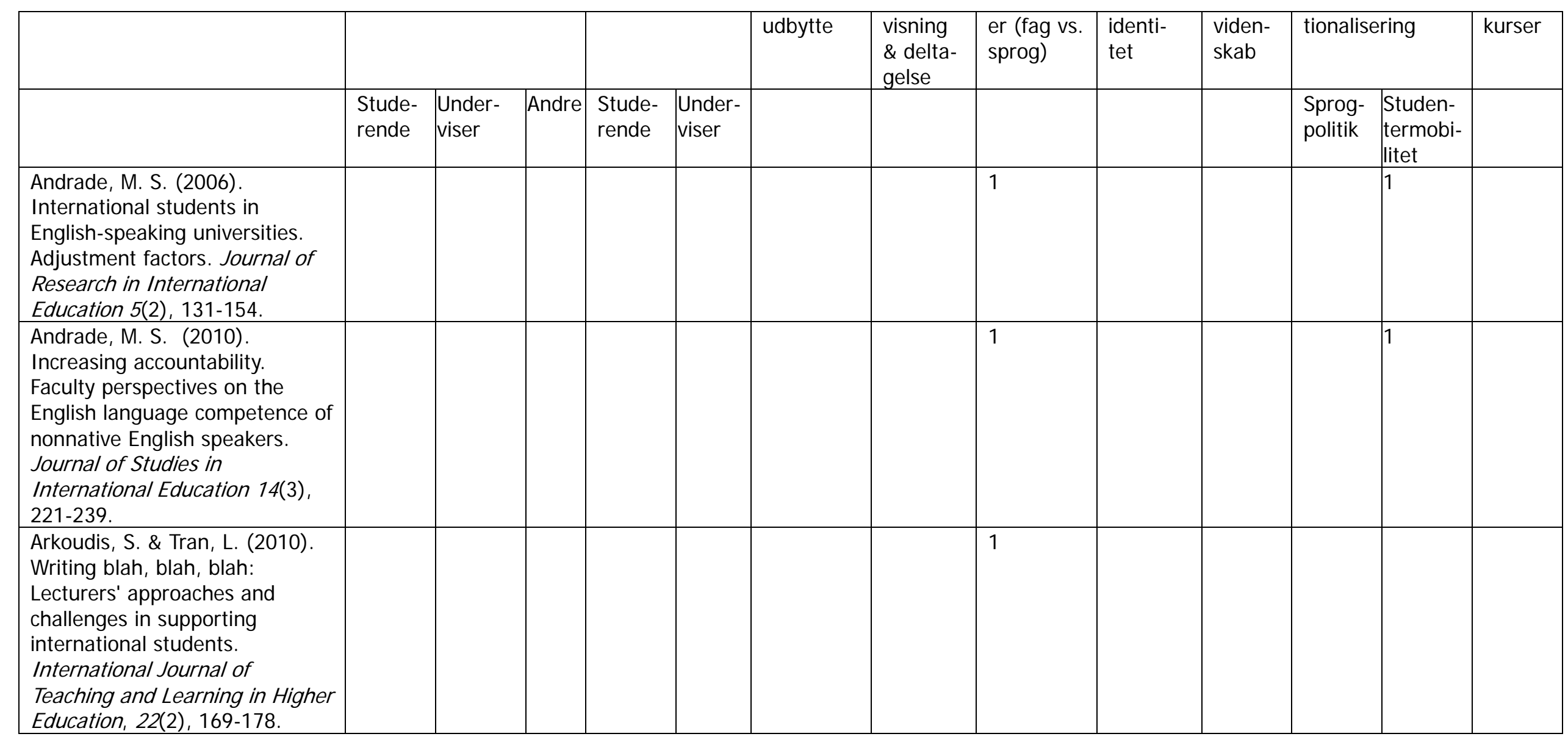




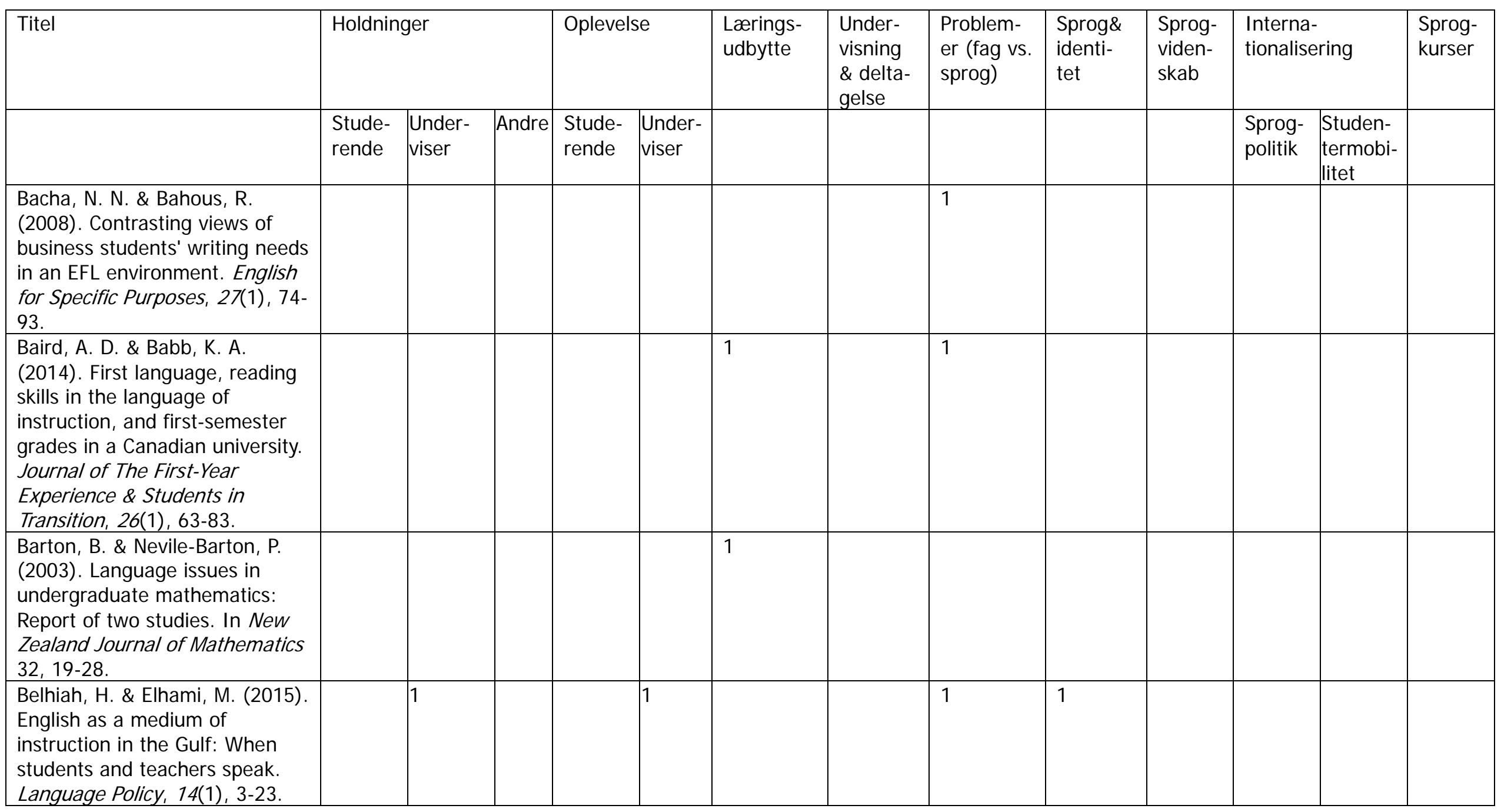




\begin{tabular}{|c|c|c|c|c|c|c|c|c|c|c|c|c|c|}
\hline Titel & Holdnin & ger & & Opleve & & $\begin{array}{l}\text { Lærings- } \\
\text { udbytte }\end{array}$ & $\begin{array}{l}\text { Under- } \\
\text { visning }\end{array}$ & $\begin{array}{l}\text { Problem- } \\
\text { er (fag vs. }\end{array}$ & $\begin{array}{l}\text { Sprog\& } \\
\text { identi- }\end{array}$ & $\begin{array}{l}\text { Sprog- } \\
\text { viden- }\end{array}$ & $\begin{array}{l}\text { Interna } \\
\text { tionalis }\end{array}$ & ering & $\begin{array}{l}\text { Sprog- } \\
\text { kurser }\end{array}$ \\
\hline & $\begin{array}{l}\text { Stude- } \\
\text { rende }\end{array}$ & $\begin{array}{l}\text { Under- } \\
\text { viser }\end{array}$ & Andre & $\begin{array}{l}\text { Stude- } \\
\text { rende }\end{array}$ & $\begin{array}{l}\text { Under- } \\
\text { viser }\end{array}$ & & & & & & $\begin{array}{l}\text { Sprog- } \\
\text { politik }\end{array}$ & \begin{tabular}{|l|} 
Studen- \\
termobi- \\
litet
\end{tabular} & \\
\hline $\begin{array}{l}\text { Bennett, R. J., Volet, S. E. \& } \\
\text { Fozdar, F. E. ( } 2013) \text {. "I' 'd say it's } \\
\text { kind of unique in a way": The } \\
\text { development of an intercultural } \\
\text { student relationship. Journal of } \\
\text { Studies in International } \\
\text { Education, } 175), 533-553 .\end{array}$ & & & & & & & & & & & & 1 & \\
\hline $\begin{array}{l}\text { Benzie, H. J. (2010). Graduating } \\
\text { as a "native speaker": } \\
\text { International students and } \\
\text { English language proficiency in } \\
\text { higher education. Higher } \\
\text { Education Research and } \\
\text { Development, 2944), 447-459. }\end{array}$ & & 1 & & & & & & 1 & & & & 1 & \\
\hline $\begin{array}{l}\text { Bifuh-Ambe, E. (2011). } \\
\text { Postsecondary learning: } \\
\text { Recognizing the needs of } \\
\text { English language learners in } \\
\text { mainstream university } \\
\text { classrooms. Multicultural } \\
\text { Education, 19(3), 13-19. }\end{array}$ & & & & & & & & 1 & & & & & \\
\hline
\end{tabular}




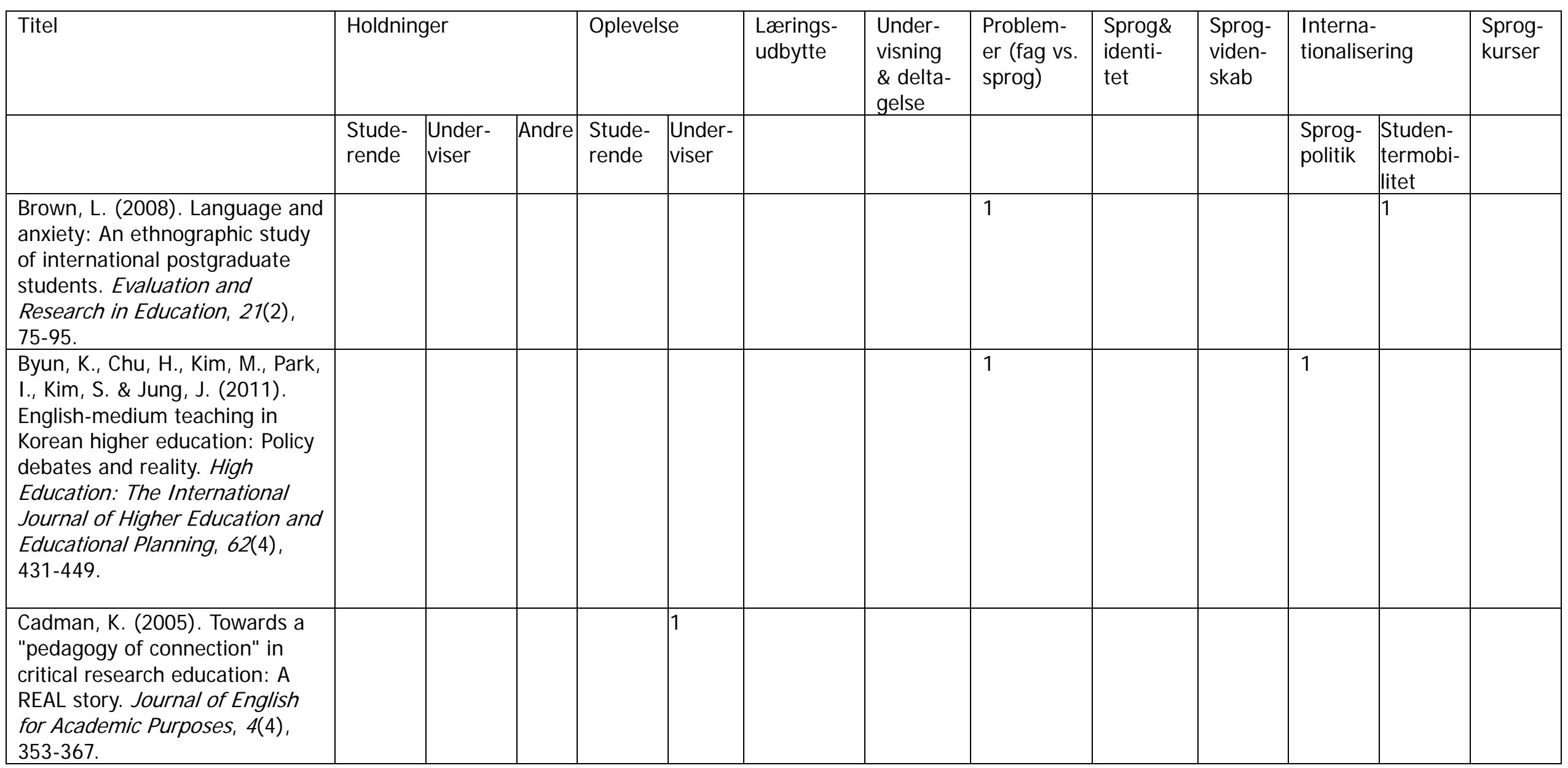




\begin{tabular}{|c|c|c|c|c|c|c|c|c|c|c|c|c|c|}
\hline \multirow[t]{2}{*}{ Titel } & \multicolumn{3}{|c|}{ Holdninger } & \multicolumn{2}{|c|}{ Oplevelse } & \multirow[t]{2}{*}{$\begin{array}{l}\text { Lærings- } \\
\text { udbytte }\end{array}$} & \multirow{2}{*}{$\begin{array}{l}\text { Under- } \\
\text { visning } \\
\& \text { delta- } \\
\text { gelse }\end{array}$} & \multirow{2}{*}{$\begin{array}{l}\text { Problem- } \\
\text { er (fag vs. } \\
\text { sprog) }\end{array}$} & \multirow{2}{*}{$\begin{array}{l}\text { Sprog\& } \\
\text { identi- } \\
\text { tet }\end{array}$} & \multirow{2}{*}{$\begin{array}{l}\text { Sprog- } \\
\text { viden- } \\
\text { skab }\end{array}$} & \multicolumn{2}{|c|}{$\begin{array}{l}\text { Interna- } \\
\text { tionalisering }\end{array}$} & \multirow[t]{2}{*}{$\begin{array}{l}\text { Sprog- } \\
\text { kurser }\end{array}$} \\
\hline & $\begin{array}{l}\text { Stude- } \\
\text { rende }\end{array}$ & $\begin{array}{l}\text { Under- } \\
\text { viser }\end{array}$ & Andre & $\begin{array}{l}\text { Stud } \\
\text { e- } \\
\text { rend } \\
\text { e }\end{array}$ & $\begin{array}{l}\text { Under- } \\
\text { viser }\end{array}$ & & & & & & $\begin{array}{l}\text { Sprog- } \\
\text { politik }\end{array}$ & $\begin{array}{l}\text { Studen- } \\
\text { termobi- } \\
\text { litet }\end{array}$ & \\
\hline $\begin{array}{l}\text { Canagarajah, A. S. (2010). } \\
\text { Challenges in English literacy for } \\
\text { African-American and Lankan } \\
\text { Tamil learners: Towards a } \\
\text { pedagogical paradigm for } \\
\text { bidialectal and bilingual minority } \\
\text { students. Language and } \\
\text { Education, } 11(1), 15-37 .\end{array}$ & & & & & & & & & 1 & & & & \\
\hline $\begin{array}{l}\text { Camiciottoli, B. C. (2010). } \\
\text { Meeting the challenges of } \\
\text { European student mobility: } \\
\text { Preparing Italian Erasmus } \\
\text { students for business lectures in } \\
\text { English. English for Specific } \\
\text { Purposes, 294), 268-280. }\end{array}$ & & & & 1 & & & & 1 & & & & 1 & \\
\hline $\begin{array}{l}\text { Cavazos, A. G. (2015). } \\
\text { Multilingual faculty across } \\
\text { academic disciplines: Language } \\
\text { difference in scholarship. } \\
\text { Language and Education, 294), } \\
\text { 317-331. }\end{array}$ & & & & & & & & & & 1 & & & \\
\hline
\end{tabular}




\begin{tabular}{|c|c|c|c|c|c|c|c|c|c|c|c|c|c|}
\hline \multirow[t]{2}{*}{ Titel } & \multicolumn{3}{|c|}{ Holdninger } & \multicolumn{2}{|c|}{ Oplevelse } & \multirow[t]{2}{*}{$\begin{array}{l}\text { Lærings- } \\
\text { udbytte }\end{array}$} & \multirow{2}{*}{$\begin{array}{l}\text { Under- } \\
\text { visning } \\
\text { \& delta- } \\
\text { gelse }\end{array}$} & \multirow{2}{*}{$\begin{array}{l}\text { Problem- } \\
\text { er (fag vs. } \\
\text { sprog) }\end{array}$} & \multirow{2}{*}{$\begin{array}{l}\text { Sprog\& } \\
\text { identi- } \\
\text { tet }\end{array}$} & \multirow{2}{*}{$\begin{array}{l}\text { Sprog- } \\
\text { viden- } \\
\text { skab }\end{array}$} & \multicolumn{2}{|c|}{$\begin{array}{l}\text { Interna- } \\
\text { tionalisering }\end{array}$} & \multirow[t]{2}{*}{$\begin{array}{l}\text { Sprog- } \\
\text { kurser }\end{array}$} \\
\hline & $\begin{array}{l}\text { Stude- } \\
\text { rende }\end{array}$ & $\begin{array}{l}\text { Under- } \\
\text { viser }\end{array}$ & Andre & $\begin{array}{l}\text { Stude- } \\
\text { rende }\end{array}$ & $\begin{array}{l}\text { Under- } \\
\text { viser }\end{array}$ & & & & & & $\begin{array}{l}\text { Sprog- } \\
\text { politik }\end{array}$ & \begin{tabular}{|l|} 
Studen- \\
termobi- \\
litet
\end{tabular} & \\
\hline $\begin{array}{l}\text { Chakrani, B. \& Huang, J. L. } \\
\text { (2014). The work of ideology: } \\
\text { Examining class, language use, } \\
\text { and attitudes among Moroccan } \\
\text { university students. } \\
\text { International Journal of Bilingual } \\
\text { Education and Bilingualism, } \\
1 \pi(1), 1-14 .\end{array}$ & 1 & & & & & & & & 1 & & & & \\
\hline $\begin{array}{l}\text { Chamberlin-Quinlisk, C. (2010). } \\
\text { Language learner/native } \\
\text { speaker interactions: Exploring } \\
\text { adaptability in intercultural } \\
\text { encounters. Intercultural } \\
\text { Education, 21(4), 365-377. }\end{array}$ & & & & & & & & 1 & & & & 1 & \\
\hline $\begin{array}{l}\text { Cheng, L. \& Fox, J. (2008). } \\
\text { Towards a better understanding } \\
\text { of academic acculturation: } \\
\text { Second language students in } \\
\text { Canadian universities. Canadian } \\
\text { Modern Language Review, } \\
\text { 65(2), 307-333. }\end{array}$ & & & & & & & & & & & & 1 & \\
\hline
\end{tabular}




\begin{tabular}{|c|c|c|c|c|c|c|c|c|c|c|c|c|c|}
\hline \multirow[t]{2}{*}{ Titel } & \multicolumn{3}{|c|}{ Holdninger } & \multicolumn{2}{|c|}{ Oplevelse } & \multirow[t]{2}{*}{$\begin{array}{l}\text { Lærings- } \\
\text { udbytte }\end{array}$} & \multirow{2}{*}{$\begin{array}{l}\text { Under- } \\
\text { visning } \\
\& \text { delta- } \\
\text { gelse }\end{array}$} & \multirow{2}{*}{$\begin{array}{l}\text { Problem- } \\
\text { er (fag vs. } \\
\text { sprog) }\end{array}$} & \multirow{2}{*}{$\begin{array}{l}\text { Sprog\& } \\
\text { identi- } \\
\text { tet }\end{array}$} & \multirow{2}{*}{$\begin{array}{l}\text { Sprog- } \\
\text { viden- } \\
\text { skab }\end{array}$} & \multicolumn{2}{|c|}{$\begin{array}{l}\text { Interna- } \\
\text { tionalisering }\end{array}$} & \multirow[t]{2}{*}{$\begin{array}{l}\text { Sprog- } \\
\text { kurser }\end{array}$} \\
\hline & $\begin{array}{l}\text { Stude- } \\
\text { rende }\end{array}$ & $\begin{array}{l}\text { Under- } \\
\text { viser }\end{array}$ & Andre & $\begin{array}{l}\text { Stude- } \\
\text { rende }\end{array}$ & $\begin{array}{l}\text { Under- } \\
\text { viser }\end{array}$ & & & & & & $\begin{array}{l}\text { Sprog- } \\
\text { politik }\end{array}$ & $\begin{array}{l}\text { Studen- } \\
\text { termobi- } \\
\text { litet }\end{array}$ & \\
\hline $\begin{array}{l}\text { Clarence, S., Albertus, L. \& } \\
\text { Mwambene, L. (2014). Building } \\
\text { an evolving method and } \\
\text { materials for teaching legal } \\
\text { writing in large classes. Higher } \\
\text { Education: The International } \\
\text { Journal of Higher Education and } \\
\text { Educational Planning, 676), } \\
\text { 839-851. }\end{array}$ & & & & & & & & 1 & & & & & \\
\hline $\begin{array}{l}\text { Coleman, J. A. (2006). English- } \\
\text { medium teaching in European } \\
\text { Higher education. Language } \\
\text { Teaching, 39(1), 1-14. }\end{array}$ & & & & & & & & & & & 1 & & \\
\hline $\begin{array}{l}\text { Coley, M. (1999). The English } \\
\text { language entry requirements of } \\
\text { Australian universities for } \\
\text { students of non-English } \\
\text { speaking background. Higher } \\
\text { Education Research \& } \\
\text { Development, 18(1), 7-17. }\end{array}$ & & & & & & & & 1 & & & & 1 & \\
\hline
\end{tabular}




\begin{tabular}{|c|c|c|c|c|c|c|c|c|c|c|c|c|c|}
\hline Titel & Holdning & & & Opleve & & $\begin{array}{l}\text { Lærings- } \\
\text { udbytte }\end{array}$ & $\begin{array}{l}\text { Under- } \\
\text { visning }\end{array}$ & $\begin{array}{l}\text { Problem- } \\
\text { er (fag vs. }\end{array}$ & $\begin{array}{l}\text { Sprog\& } \\
\text { identi- }\end{array}$ & $\begin{array}{l}\text { Sprog- } \\
\text { viden- }\end{array}$ & $\begin{array}{l}\text { Interna } \\
\text { tionalis }\end{array}$ & ering & $\begin{array}{l}\text { Sprog- } \\
\text { kurser }\end{array}$ \\
\hline & $\begin{array}{l}\text { Stude- } \\
\text { rende }\end{array}$ & $\begin{array}{l}\text { Under- } \\
\text { viser }\end{array}$ & Andre & $\begin{array}{l}\text { Stude- } \\
\text { rende }\end{array}$ & $\begin{array}{l}\text { Under- } \\
\text { viser }\end{array}$ & & & & & & $\begin{array}{l}\text { Sprog- } \\
\text { politik }\end{array}$ & \begin{tabular}{|l|} 
Studen- \\
termobi- \\
litet
\end{tabular} & \\
\hline $\begin{array}{l}\text { Dafouz, E., Camacho, M. \& } \\
\text { Urquia, E. (2014). "Surely they } \\
\text { can't do as well": A comparison } \\
\text { of business students' academic } \\
\text { performance in English-medium } \\
\text { and Spanish-as-first-language- } \\
\text { medium programmes. Language } \\
\text { and Education, 28(3), 223-236. }\end{array}$ & & & & & & 1 & & & & & & & \\
\hline $\begin{array}{l}\text { Davis, B. D. (2006). Student } \\
\text { perceptions of the acceptance } \\
\text { of communication diverseness. } \\
\text { Journal of Education for } \\
\text { Business, 82(2), 67-73. }\end{array}$ & 1 & & & & & & & & & & & & \\
\hline $\begin{array}{l}\text { de Jong, E. (2013). Preparing } \\
\text { mainstream teachers for } \\
\text { multilingual classrooms. Journal } \\
\text { of the Association of Mexican } \\
\text { American Educators, } 72 \text { (2), 40- } \\
49 .\end{array}$ & & & & & & & 1 & & & & & & \\
\hline
\end{tabular}




\begin{tabular}{|c|c|c|c|c|c|c|c|c|c|c|c|c|c|}
\hline Titel & Holdnir & ger & & Oplevels & & $\begin{array}{l}\text { Lærings- } \\
\text { udbyttee }\end{array}$ & $\begin{array}{l}\text { Under- } \\
\text { visning }\end{array}$ & $\begin{array}{l}\text { Problem- } \\
\text { er (fag vs. }\end{array}$ & $\begin{array}{l}\text { Sprog\& } \\
\text { identi- }\end{array}$ & $\begin{array}{l}\text { Sprog- } \\
\text { viden- }\end{array}$ & $\begin{array}{l}\text { Interna } \\
\text { tionalis }\end{array}$ & ering & $\begin{array}{l}\text { Sprog- } \\
\text { kurser }\end{array}$ \\
\hline & $\begin{array}{l}\text { Stude- } \\
\text { rende }\end{array}$ & $\begin{array}{l}\text { Under- } \\
\text { viser }\end{array}$ & Andre & $\begin{array}{l}\text { Stude- } \\
\text { rende }\end{array}$ & $\begin{array}{l}\text { Under- } \\
\text { viser }\end{array}$ & & & & & & $\begin{array}{l}\text { Sprog- } \\
\text { politik }\end{array}$ & $\begin{array}{l}\text { Studen- } \\
\text { termobi- } \\
\text { litet }\end{array}$ & \\
\hline $\begin{array}{l}\text { Doiz, A., Lasagabaster, D. \& } \\
\text { Sierra, J. M. (2011). } \\
\text { Internationalization, } \\
\text { multilingualism and English- } \\
\text { medium instruction. World } \\
\text { Englishes, 303), 345-359. }\end{array}$ & & 1 & & & & & 1 & & & & & & \\
\hline $\begin{array}{l}\text { Doiz, A., Lasagabaster, D. \& } \\
\text { Sierra, J. M. (2013). } \\
\text { Globalization, } \\
\text { internationalization, } \\
\text { multilingualism and linguistic } \\
\text { strains in higher education. } \\
\text { Studies in Higher Education, } \\
\text { 38(9), 1407-1421. }\end{array}$ & 1 & 1 & 1 & & & & & & & & & & \\
\hline $\begin{array}{l}\text { Doiz, A., Lasagabaster, D. \& } \\
\text { Sierra, J. M. (2014). What does } \\
\text { "international university" mean } \\
\text { at a European bilingual } \\
\text { university? The role of } \\
\text { languages and culture. } \\
\text { Language Awareness, 23(1-2), } \\
\text { 172-186. }\end{array}$ & & & & & & & & & & & 1 & & \\
\hline
\end{tabular}




\begin{tabular}{|c|c|c|c|c|c|c|c|c|c|c|c|c|c|}
\hline Titel & Holdning & & & Opleve & & $\begin{array}{l}\text { Lærings- } \\
\text { udbytte }\end{array}$ & $\begin{array}{l}\text { Under- } \\
\text { visning }\end{array}$ & $\begin{array}{l}\text { Problem- } \\
\text { er (fag vs. }\end{array}$ & $\begin{array}{l}\text { Sprog\& } \\
\text { identi- }\end{array}$ & $\begin{array}{l}\text { Sprog- } \\
\text { viden- }\end{array}$ & $\begin{array}{l}\text { Interna } \\
\text { tionalis }\end{array}$ & ering & $\begin{array}{l}\text { Sprog- } \\
\text { kurser }\end{array}$ \\
\hline & $\begin{array}{l}\text { Stude- } \\
\text { rende }\end{array}$ & $\begin{array}{l}\text { Under- } \\
\text { viser }\end{array}$ & Andre & $\begin{array}{l}\text { Stude- } \\
\text { rende }\end{array}$ & $\begin{array}{l}\text { Under- } \\
\text { viser }\end{array}$ & & & & & & $\begin{array}{l}\text { Sprog- } \\
\text { politik }\end{array}$ & \begin{tabular}{|l} 
Studen- \\
termobi- \\
litet
\end{tabular} & \\
\hline $\begin{array}{l}\text { Earls, C. W. (2014). Striking the } \\
\text { balance: The role of English and } \\
\text { German in a multilingual } \\
\text { English-medium degree } \\
\text { programme in German higher } \\
\text { education. Current Issues in } \\
\text { Language Planning, 15(2),153- } \\
173 .\end{array}$ & & & & 1 & & & & & & & & & \\
\hline $\begin{array}{l}\text { Evans, S. \& Morrison, B. (2011). } \\
\text { The student experience of } \\
\text { English-medium higher } \\
\text { education in Hong Kong. } \\
\text { Language and Education, 25(2), } \\
\text { 147-162. }\end{array}$ & & & & & & & & 1 & & & 1 & & \\
\hline $\begin{array}{l}\text { Evans, S. \& Morrison, B. (2011). } \\
\text { Meeting the challenges of } \\
\text { English-medium higher } \\
\text { education: The first-year } \\
\text { experience in Hong Kong. } \\
\text { English for Specific Purposes, } \\
\text { 3a3), 198-208. }\end{array}$ & & & & & & & & & & & & & \\
\hline
\end{tabular}




\begin{tabular}{|c|c|c|c|c|c|c|c|c|c|c|c|c|c|}
\hline \multirow[t]{2}{*}{ Titel } & \multicolumn{3}{|c|}{ Holdninger } & \multicolumn{2}{|c|}{ Oplevelse } & \multirow[t]{2}{*}{$\begin{array}{l}\text { Lærings- } \\
\text { udbytte }\end{array}$} & \multirow{2}{*}{$\begin{array}{l}\text { Under- } \\
\text { visning\& } \\
\text { delta- } \\
\text { gelse }\end{array}$} & \multirow{2}{*}{$\begin{array}{l}\text { Problem- } \\
\text { er (fag vs. } \\
\text { sprog) }\end{array}$} & \multirow{2}{*}{$\begin{array}{l}\text { Sprog\& } \\
\text { identi- } \\
\text { tet }\end{array}$} & \multirow{2}{*}{$\begin{array}{l}\text { Sprog- } \\
\text { viden- } \\
\text { skab }\end{array}$} & \multicolumn{2}{|c|}{$\begin{array}{l}\text { Interna- } \\
\text { tionalisering }\end{array}$} & \multirow[t]{2}{*}{$\begin{array}{l}\text { Sprog- } \\
\text { kurser }\end{array}$} \\
\hline & $\begin{array}{l}\text { Stude- } \\
\text { rende }\end{array}$ & $\begin{array}{l}\text { Under- } \\
\text { viser }\end{array}$ & Andre & $\begin{array}{l}\text { Stude- } \\
\text { rende }\end{array}$ & $\begin{array}{l}\text { Under- } \\
\text { viser }\end{array}$ & & & & & & $\begin{array}{l}\text { Sprog- } \\
\text { politik }\end{array}$ & $\begin{array}{l}\text { Studen- } \\
\text { termobi- } \\
\text { litet }\end{array}$ & \\
\hline $\begin{array}{l}\text { Findlow, S. (2006). Higher } \\
\text { education and linguistic dualism } \\
\text { in the Arab Gulf. British Journal } \\
\text { of Sociology of Education, } \\
2 \pi(1), 19-36 \text {. }\end{array}$ & & & & & & & & & 1 & & & & \\
\hline $\begin{array}{l}\text { Floris, D. F. (2014). Learning } \\
\text { subject matter through English } \\
\text { as the medium of instruction: } \\
\text { students' and teachers' } \\
\text { perspectives. Asian Englishes, } \\
\text { 16(1), 47-59. }\end{array}$ & 1 & 1 & & & & & & & & & & & \\
\hline $\begin{array}{l}\text { Flowerdew, J. \& Miller, L. } \\
\text { (1996). Lectures in a second } \\
\text { language: Notes towards a } \\
\text { cultural grammar. English for } \\
\text { Specific Purposes, 15(2), 121- } \\
140 \text {. }\end{array}$ & 1 & 1 & & & & & & & & & & & \\
\hline
\end{tabular}




\begin{tabular}{|c|c|c|c|c|c|c|c|c|c|c|c|c|c|}
\hline \multirow[t]{2}{*}{ Titel } & \multicolumn{3}{|c|}{ Holdninger } & \multicolumn{2}{|c|}{ Oplevelse } & \multirow[t]{2}{*}{$\begin{array}{l}\text { Lærings- } \\
\text { udbytte }\end{array}$} & \multirow{2}{*}{$\begin{array}{l}\text { Under- } \\
\text { visning } \\
\& \text { delta- } \\
\text { gelse } \\
\end{array}$} & \multirow{2}{*}{$\begin{array}{l}\text { Problem- } \\
\text { er (fag vs. } \\
\text { sprog) }\end{array}$} & \multirow{2}{*}{$\begin{array}{l}\text { Sprog\& } \\
\text { identi- } \\
\text { tet }\end{array}$} & \multirow{2}{*}{$\begin{array}{l}\text { Sprog- } \\
\text { viden- } \\
\text { skab }\end{array}$} & \multicolumn{2}{|c|}{$\begin{array}{l}\text { Interna- } \\
\text { tionalisering }\end{array}$} & \multirow[t]{2}{*}{$\begin{array}{l}\text { Sprog- } \\
\text { kurser }\end{array}$} \\
\hline & $\begin{array}{l}\text { Stude- } \\
\text { rende }\end{array}$ & $\begin{array}{l}\text { Under- } \\
\text { viser }\end{array}$ & Andre & $\begin{array}{l}\text { Stude- } \\
\text { rende }\end{array}$ & $\begin{array}{l}\text { Under- } \\
\text { viser }\end{array}$ & & & & & & $\begin{array}{l}\text { Sprog- } \\
\text { politik }\end{array}$ & \begin{tabular}{|l|} 
Studen- \\
termobi- \\
litet
\end{tabular} & \\
\hline $\begin{array}{l}\text { Garner, M. \& Borg, E. (2005). } \\
\text { An ecological perspective on } \\
\text { content-based instruction. } \\
\text { Journal of English for Academic } \\
\text { Purposes, } 4(2), 119-134 .\end{array}$ & & & & & & & & & & & & & 1 \\
\hline $\begin{array}{l}\text { Gerber, A., Engelbrecht, J., } \\
\text { Harding, A. \& Rogan, J. (2005). } \\
\text { The influence of second } \\
\text { language teaching on } \\
\text { undergraduate mathematics } \\
\text { performance. Mathematics } \\
\text { Education Research Journal } \\
1 \pi(3), 3-21 .\end{array}$ & & & & & & 1 & & & & & & & \\
\hline $\begin{array}{l}\text { Ghorbani, M. R. \& Alavi, S. Z. } \\
\text { (2014). Feasibility of adopting } \\
\text { English-medium instruction at } \\
\text { I ranian universities. Current } \\
\text { Issues in Education, } 1 \pi(1) .\end{array}$ & 1 & 1 & & & & & & & & & & & \\
\hline
\end{tabular}




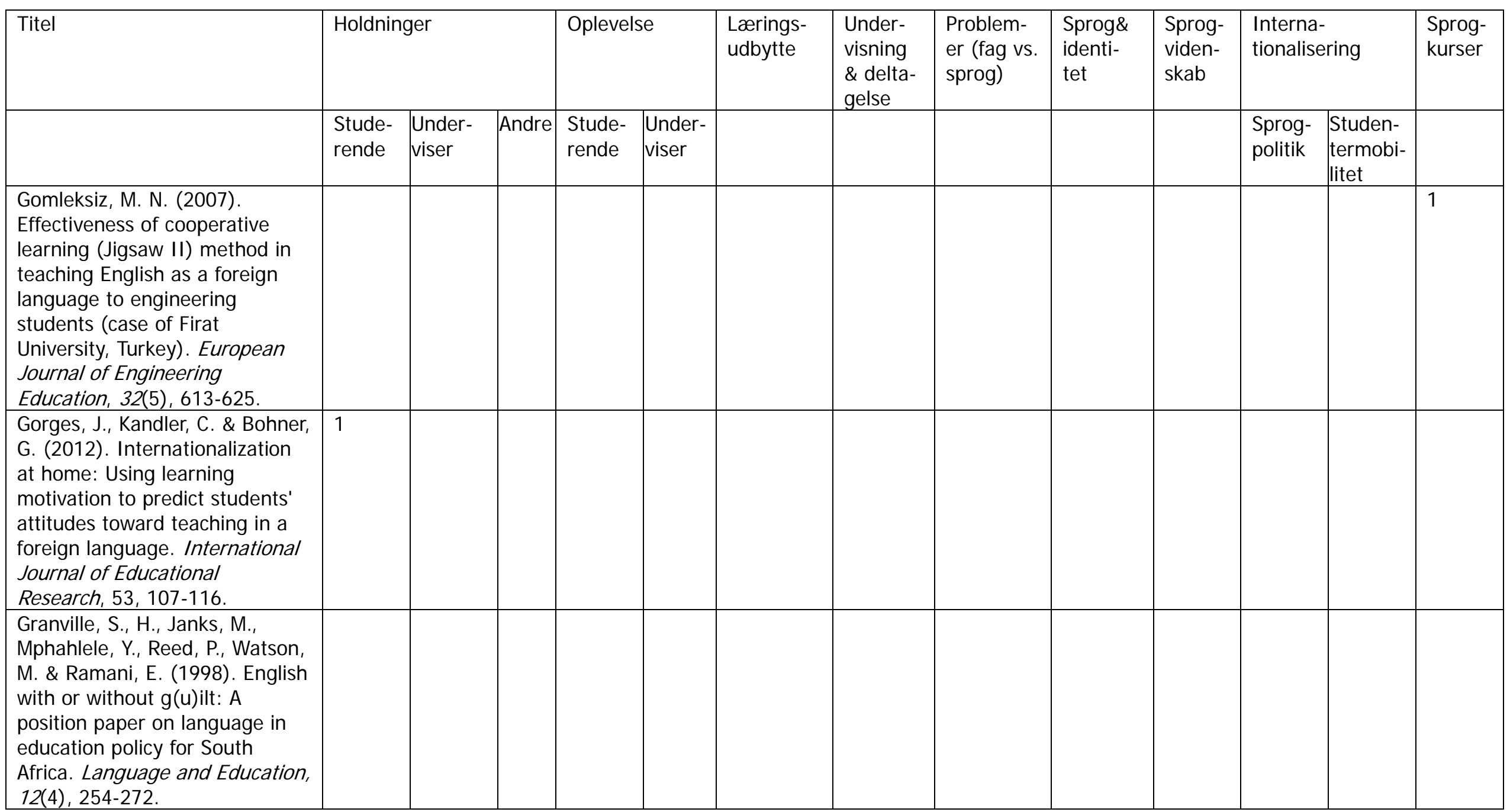




\begin{tabular}{|c|c|c|c|c|c|c|c|c|c|c|c|c|c|}
\hline \multirow[t]{2}{*}{ Titel } & \multicolumn{3}{|c|}{ Holdninger } & \multicolumn{2}{|c|}{ Oplevelse } & \multirow[t]{2}{*}{$\begin{array}{l}\text { Lærings- } \\
\text { udbytte }\end{array}$} & \multirow{2}{*}{$\begin{array}{l}\text { Under- } \\
\text { visning } \\
\& \text { delta- } \\
\text { gelse }\end{array}$} & \multirow{2}{*}{$\begin{array}{l}\text { Problem- } \\
\text { er (fag vs. } \\
\text { sprog) }\end{array}$} & \multirow{2}{*}{$\begin{array}{l}\text { Sprog\& } \\
\text { identi- } \\
\text { tet }\end{array}$} & \multirow{2}{*}{$\begin{array}{l}\text { Sprog- } \\
\text { viden- } \\
\text { skab }\end{array}$} & \multicolumn{2}{|c|}{$\begin{array}{l}\text { Interna- } \\
\text { tionalisering }\end{array}$} & \multirow[t]{2}{*}{$\begin{array}{l}\text { Sprog- } \\
\text { kurser }\end{array}$} \\
\hline & $\begin{array}{l}\text { Stude- } \\
\text { rende }\end{array}$ & $\begin{array}{l}\text { Under- } \\
\text { viser }\end{array}$ & Andre & $\begin{array}{l}\text { Stude- } \\
\text { rende }\end{array}$ & $\begin{array}{l}\text { Under- } \\
\text { viser }\end{array}$ & & & & & & $\begin{array}{l}\text { Sprog- } \\
\text { politik }\end{array}$ & $\begin{array}{l}\text { Studen- } \\
\text { termobi- } \\
\text { litet }\end{array}$ & \\
\hline $\begin{array}{l}\text { Gu, M. M. \& Tong, H. K. (2012). } \\
\text { Space, scale and languages: } \\
\text { identity construction of cross- } \\
\text { boundary students in a } \\
\text { multilingual university in Hong } \\
\text { Kong. Language and Education } \\
\text { 266), 501-515. }\end{array}$ & & & & & & & & & 1 & & & & \\
\hline $\begin{array}{l}\text { Hamid, M. O., J ahan, I. \& Islam, } \\
\text { M. M. (2013). Medium of } \\
\text { instruction policies and } \\
\text { language practices, ideologies } \\
\text { and institutional divides: Voices } \\
\text { of teachers and students in a } \\
\text { private university in Bangladesh. } \\
\text { Current Issues in Language } \\
\text { Planning, 14(1), 144-163. }\end{array}$ & 1 & 1 & & & & & & & & & 1 & & \\
\hline
\end{tabular}




\begin{tabular}{|c|c|c|c|c|c|c|c|c|c|c|c|c|c|}
\hline Titel & Holdning & iger & & Oplevels & & $\begin{array}{l}\text { Lærings- } \\
\text { udbytte }\end{array}$ & $\begin{array}{l}\text { Under- } \\
\text { visning }\end{array}$ & $\begin{array}{l}\text { Problem- } \\
\text { er (fag vs. }\end{array}$ & $\begin{array}{l}\text { Sprog\& } \\
\text { identi- }\end{array}$ & $\begin{array}{l}\text { Sprog- } \\
\text { viden- }\end{array}$ & $\begin{array}{l}\text { Interna } \\
\text { tionalis }\end{array}$ & ering & $\begin{array}{l}\text { Sprog- } \\
\text { kurser }\end{array}$ \\
\hline & $\begin{array}{l}\text { Stude- } \\
\text { rende }\end{array}$ & $\begin{array}{l}\text { Under- } \\
\text { viser }\end{array}$ & Andre & $\begin{array}{l}\text { Stude- } \\
\text { rende }\end{array}$ & $\begin{array}{l}\text { Under- } \\
\text { viser }\end{array}$ & & & & & & $\begin{array}{l}\text { Sprog- } \\
\text { politik }\end{array}$ & $\begin{array}{l}\text { Studen- } \\
\text { termobi- } \\
\text { litet }\end{array}$ & \\
\hline $\begin{array}{l}\text { Hardwick, S. W. \& Davis, R. L. } \\
\text { (2009). Content-based language } \\
\text { instruction: A new window of } \\
\text { opportunity in geography } \\
\text { education. Journal of } \\
\text { Geography, 108(4-5), 163-173. }\end{array}$ & & & & & & & & & & & & & 1 \\
\hline $\begin{array}{l}\text { Hellstén, M. \& Prescott, A. } \\
\text { (2004). Learning at university: } \\
\text { The international student } \\
\text { experience. International } \\
\text { Education Journal, 5(3), 344- } \\
\text { 351. }\end{array}$ & & & & & & & & & & & & 1 & \\
\hline $\begin{array}{l}\text { Harrison, S. \& Morgan, R. } \\
\text { (2012). Using simplified English } \\
\text { to identify potential problems } \\
\text { for non-native speakers in the } \\
\text { language of engineering } \\
\text { examination papers. Language } \\
\text { Learning Journal, } 401 \text { 1), 113- } \\
123 .\end{array}$ & & & & & & & & 1 & & & & & \\
\hline
\end{tabular}




\begin{tabular}{|c|c|c|c|c|c|c|c|c|c|c|c|c|c|}
\hline \multirow[t]{2}{*}{ Titel } & \multicolumn{3}{|c|}{ Holdninger } & \multicolumn{2}{|c|}{ Oplevelse } & \multirow{2}{*}{$\begin{array}{l}\text { Læ- } \\
\text { rings- } \\
\text { udbyt- } \\
\text { te }\end{array}$} & \multirow{2}{*}{$\begin{array}{l}\text { Under- } \\
\text { visning } \\
\& \text { delta- } \\
\text { gelse } \\
\end{array}$} & \multirow{2}{*}{$\begin{array}{l}\text { Problem- } \\
\text { er (fag vs. } \\
\text { sprog) }\end{array}$} & \multirow{2}{*}{$\begin{array}{l}\text { Sprog\& } \\
\text { identi- } \\
\text { tet }\end{array}$} & \multirow{2}{*}{$\begin{array}{l}\text { Sprog- } \\
\text { viden- } \\
\text { skab }\end{array}$} & \multicolumn{2}{|c|}{$\begin{array}{l}\text { Interna- } \\
\text { tionalisering }\end{array}$} & \multirow[t]{2}{*}{$\begin{array}{l}\text { Sprog- } \\
\text { kurser }\end{array}$} \\
\hline & $\begin{array}{l}\text { Stude- } \\
\text { rende }\end{array}$ & $\begin{array}{l}\text { Under- } \\
\text { viser }\end{array}$ & Andre & $\begin{array}{l}\text { Stude- } \\
\text { rende }\end{array}$ & $\begin{array}{l}\text { Under- } \\
\text { viser }\end{array}$ & & & & & & $\begin{array}{l}\text { Sprog- } \\
\text { politik }\end{array}$ & $\begin{array}{l}\text { Studen- } \\
\text { termobi- } \\
\text { litet }\end{array}$ & \\
\hline $\begin{array}{l}\text { Hellstén, M. \& Prescott, A. } \\
\text { (2004). Learning at university: } \\
\text { The international student } \\
\text { experience. International } \\
\text { Education Journal, 5(3), 344- } \\
\text { 351. }\end{array}$ & & & & & & & & & & & & & \\
\hline $\begin{array}{l}\text { Henderson, J. (2009). "It's all } \\
\text { about give and take," or is it? } \\
\text { Where, when and how do } \\
\text { native and non-native uses of } \\
\text { English shape U.K. university } \\
\text { students' representations of } \\
\text { each other and their learning } \\
\text { experience. Journal of Studies } \\
\text { in International Education, } \\
\text { 13(3), 398-409. }\end{array}$ & & & & 1 & & & & & 1 & & & 1 & \\
\hline
\end{tabular}




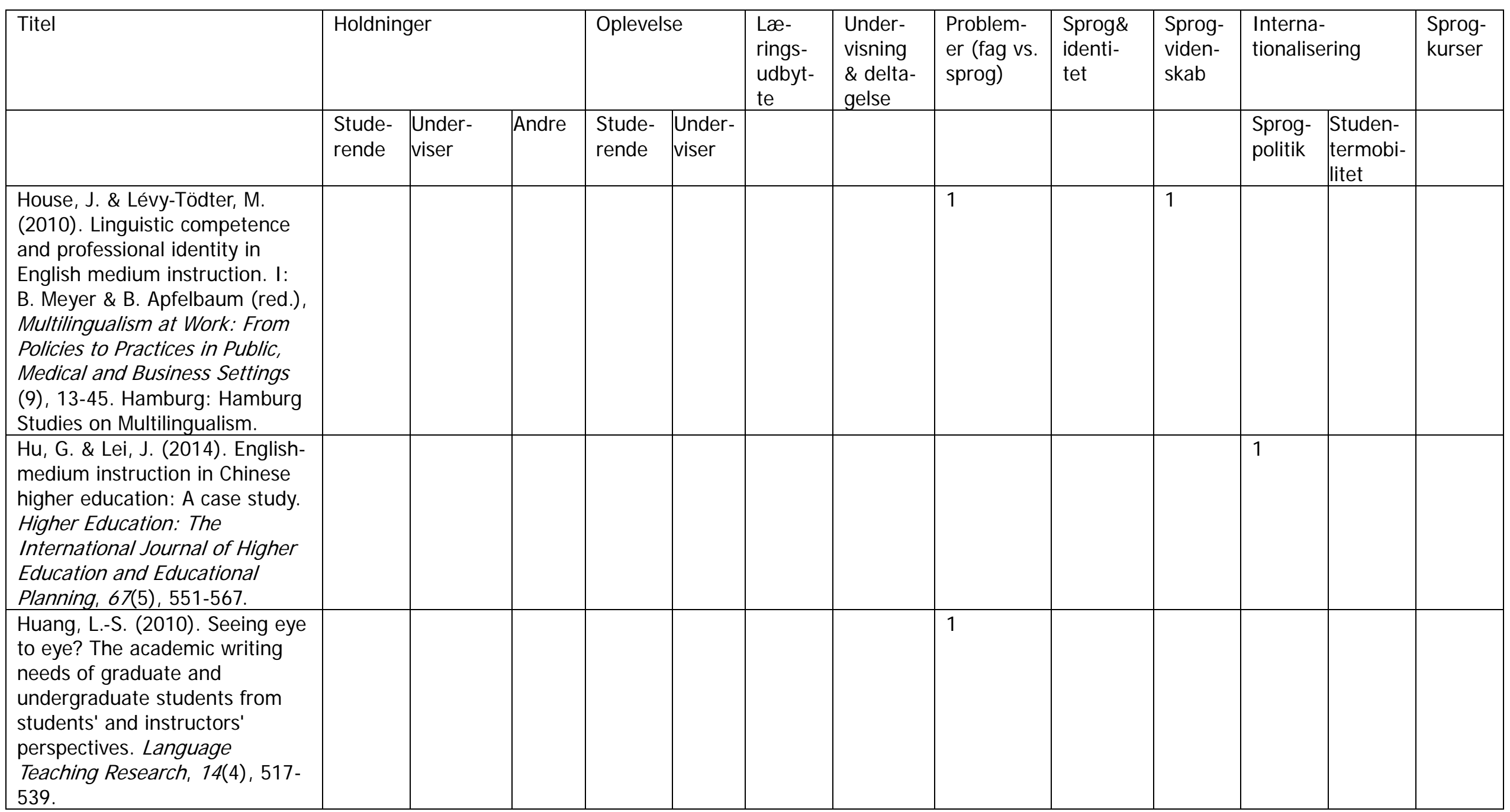




\begin{tabular}{|c|c|c|c|c|c|c|c|c|c|c|c|c|c|}
\hline \multirow[t]{2}{*}{ Titel } & \multicolumn{3}{|c|}{ Holdninger } & \multicolumn{2}{|c|}{ Oplevelse } & \multirow{2}{*}{$\begin{array}{l}\text { Læ- } \\
\text { rings- } \\
\text { udbyt- } \\
\text { te }\end{array}$} & \multirow{2}{*}{$\begin{array}{l}\text { Under- } \\
\text { visning } \\
\& \text { delta- } \\
\text { gelse }\end{array}$} & \multirow{2}{*}{$\begin{array}{l}\text { Problem- } \\
\text { er (fag vs. } \\
\text { sprog) }\end{array}$} & \multirow{2}{*}{$\begin{array}{l}\text { Sprog\& } \\
\text { identi- } \\
\text { tet }\end{array}$} & \multirow{2}{*}{$\begin{array}{l}\text { Sprog- } \\
\text { viden- } \\
\text { skab }\end{array}$} & \multicolumn{2}{|c|}{$\begin{array}{l}\text { Interna- } \\
\text { tionalisering }\end{array}$} & \multirow[t]{2}{*}{$\begin{array}{l}\text { Sprog- } \\
\text { kurser }\end{array}$} \\
\hline & $\begin{array}{l}\text { Stude- } \\
\text { rende }\end{array}$ & $\begin{array}{l}\text { Under- } \\
\text { viser }\end{array}$ & Andre & $\begin{array}{l}\text { Stude- } \\
\text { rende }\end{array}$ & $\begin{array}{l}\text { Under- } \\
\text { viser }\end{array}$ & & & & & & $\begin{array}{l}\text { Sprog- } \\
\text { politik }\end{array}$ & $\begin{array}{l}\text { Studen- } \\
\text { termobi- } \\
\text { litet }\end{array}$ & \\
\hline $\begin{array}{l}\text { Hurst, E. (2015). "The thing } \\
\text { that kill us": Student } \\
\text { perspectives on language } \\
\text { support in a South African } \\
\text { university. Teaching in Higher } \\
\text { Education, 2a1), 78-91. }\end{array}$ & & & & & & & & 1 & & & & & \\
\hline $\begin{array}{l}\text { Hynninen, N. (2012): ICL at the } \\
\text { micro level: L2 speakers taking } \\
\text { on the role of language experts. } \\
\text { AILA Review, } 25,13-29 \text {. }\end{array}$ & & & & & & & & & 1 & 1 & & & \\
\hline $\begin{array}{l}\text { Ippolito, K. (2007). Promoting } \\
\text { intercultural learning in a } \\
\text { multicultural university: Ideals } \\
\text { and realities. Teaching in Higher } \\
\text { Education, 12(5-6), 749-763 }\end{array}$ & & & & & & & & & & & & 1 & \\
\hline
\end{tabular}




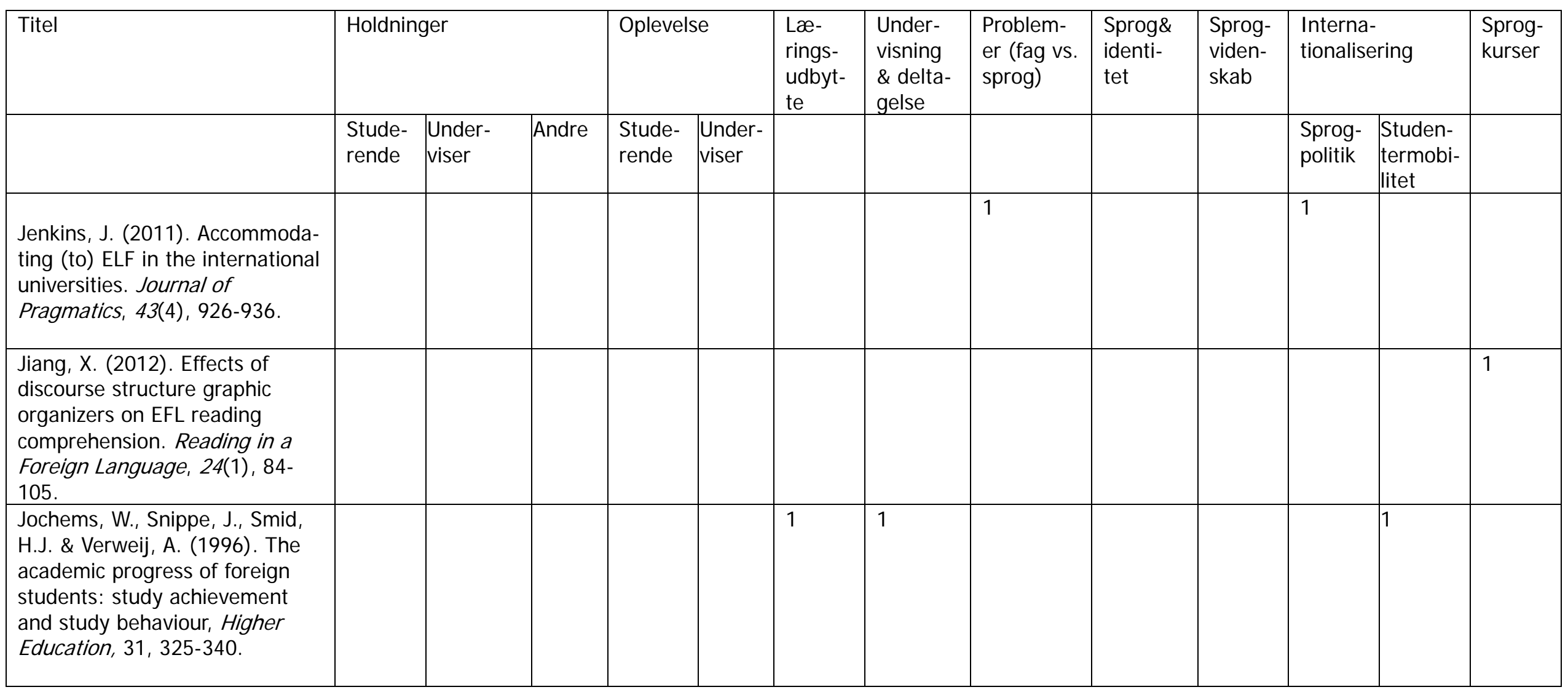




\begin{tabular}{|c|c|c|c|c|c|c|c|c|c|c|c|c|c|}
\hline Titel & Holdnin & iger & & Opleve & & $\begin{array}{l}\text { Læ- } \\
\text { rings- }\end{array}$ & $\begin{array}{l}\text { Under- } \\
\text { visning }\end{array}$ & $\begin{array}{l}\text { Problem- } \\
\text { er (fag vs. }\end{array}$ & $\begin{array}{l}\text { Sprog\& } \\
\text { identi- }\end{array}$ & $\begin{array}{l}\text { Sprog- } \\
\text { viden- }\end{array}$ & $\begin{array}{l}\text { Interna } \\
\text { tionalis }\end{array}$ & ering & $\begin{array}{l}\text { Sprog- } \\
\text { kurser }\end{array}$ \\
\hline & $\begin{array}{l}\text { Stude- } \\
\text { rende }\end{array}$ & $\begin{array}{l}\text { Under- } \\
\text { viser }\end{array}$ & Andre & $\begin{array}{l}\text { Stude- } \\
\text { rende }\end{array}$ & $\begin{array}{l}\text { Under- } \\
\text { viser }\end{array}$ & & & & & & $\begin{array}{l}\text { Sprog- } \\
\text { politik }\end{array}$ & $\begin{array}{l}\text { Studen- } \\
\text { termobi- } \\
\text { litet }\end{array}$ & \\
\hline $\begin{array}{l}\text { J on, J.-E., Lee, J. J. \& Byun, K. } \\
\text { (2014). The emergence of a } \\
\text { regional hub: Comparing } \\
\text { international student choices } \\
\text { and experiences in South Korea. } \\
\text { Higher Education: The } \\
\text { International Journal of Higher } \\
\text { Education and Educational } \\
\text { Planning, 6オ(5), 691-710. }\end{array}$ & & & & & & & & & & & & 1 & \\
\hline $\begin{array}{l}\text { Kaloscai, K. (2009). Erasmus } \\
\text { exchange students: A behind- } \\
\text { the-scenes view into an ELF } \\
\text { community of practice. Apples - } \\
\text { Journal of Applied Language } \\
\text { Studies, } 3(1), 25-49 \text {. }\end{array}$ & & & & & & & & & & & & 1 & \\
\hline $\begin{array}{l}\text { Kane, T. (2014). Whose lingua } \\
\text { franca? The politics of language } \\
\text { in transnational medical } \\
\text { education. Journal of General } \\
\text { Education, } 63(2-3), 94-112 \text {. }\end{array}$ & & & & & & & 1 & & 1 & & 1 & & \\
\hline
\end{tabular}




\begin{tabular}{|c|c|c|c|c|c|c|c|c|c|c|c|c|c|}
\hline \multirow[t]{2}{*}{ Titel } & \multicolumn{3}{|c|}{ Holdninger } & \multicolumn{2}{|c|}{ Oplevelse } & \multirow{2}{*}{$\begin{array}{l}\text { Læ- } \\
\text { rings- } \\
\text { udbyt- } \\
\text { te }\end{array}$} & \multirow{2}{*}{$\begin{array}{l}\text { Under- } \\
\text { visning } \\
\& \text { delta- } \\
\text { gelse } \\
\end{array}$} & \multirow{2}{*}{$\begin{array}{l}\text { Problem- } \\
\text { er (fag vs. } \\
\text { sprog) }\end{array}$} & \multirow{2}{*}{$\begin{array}{l}\text { Sprog\& } \\
\text { identi- } \\
\text { tet }\end{array}$} & \multirow{2}{*}{$\begin{array}{l}\text { Sprog- } \\
\text { viden- } \\
\text { skab }\end{array}$} & \multicolumn{2}{|c|}{$\begin{array}{l}\text { Interna- } \\
\text { tionalisering }\end{array}$} & \multirow[t]{2}{*}{$\begin{array}{l}\text { Sprog- } \\
\text { kurser }\end{array}$} \\
\hline & $\begin{array}{l}\text { Stude- } \\
\text { rende }\end{array}$ & $\begin{array}{l}\text { Under- } \\
\text { viser }\end{array}$ & Andre & $\begin{array}{l}\text { Stude- } \\
\text { rende }\end{array}$ & $\begin{array}{l}\text { Under- } \\
\text { viser }\end{array}$ & & & & & & $\begin{array}{l}\text { Sprog- } \\
\text { politik }\end{array}$ & $\begin{array}{l}\text { Studen- } \\
\text { termobi- } \\
\text { litet }\end{array}$ & \\
\hline $\begin{array}{l}\text { Karathanos, K. A. \& Mena, D. D. } \\
\text { (2014). Exploring the } \\
\text { experiences of linguistically } \\
\text { diverse college of education } \\
\text { student writers. Journal of } \\
\text { University Teaching and } \\
\text { Learning Practice, 11(3). }\end{array}$ & & & & & & & & 1 & & & & & \\
\hline $\begin{array}{l}\text { Kember, D., Sandra, N. G., } \\
\text { Harrison, T. S. E., Wong, E. T. } \\
\text { T. \& Pomfret, M. (1996). An } \\
\text { examination of the } \\
\text { interrelationships between } \\
\text { workload, study time, learning } \\
\text { approaches and academic } \\
\text { outcomes. Studies in Higher } \\
\text { Education, 21(3), 347-358. }\end{array}$ & & & & & & 1 & & 1 & & & & & \\
\hline $\begin{array}{l}\text { Kiliçkaya, F. (2006). Instructors' } \\
\text { attitudes toward English- } \\
\text { medium instruction in Turkey. } \\
\text { Humanising Language Teaching, } \\
\text { \&6). }\end{array}$ & & 1 & & & & & & & & & & & \\
\hline
\end{tabular}




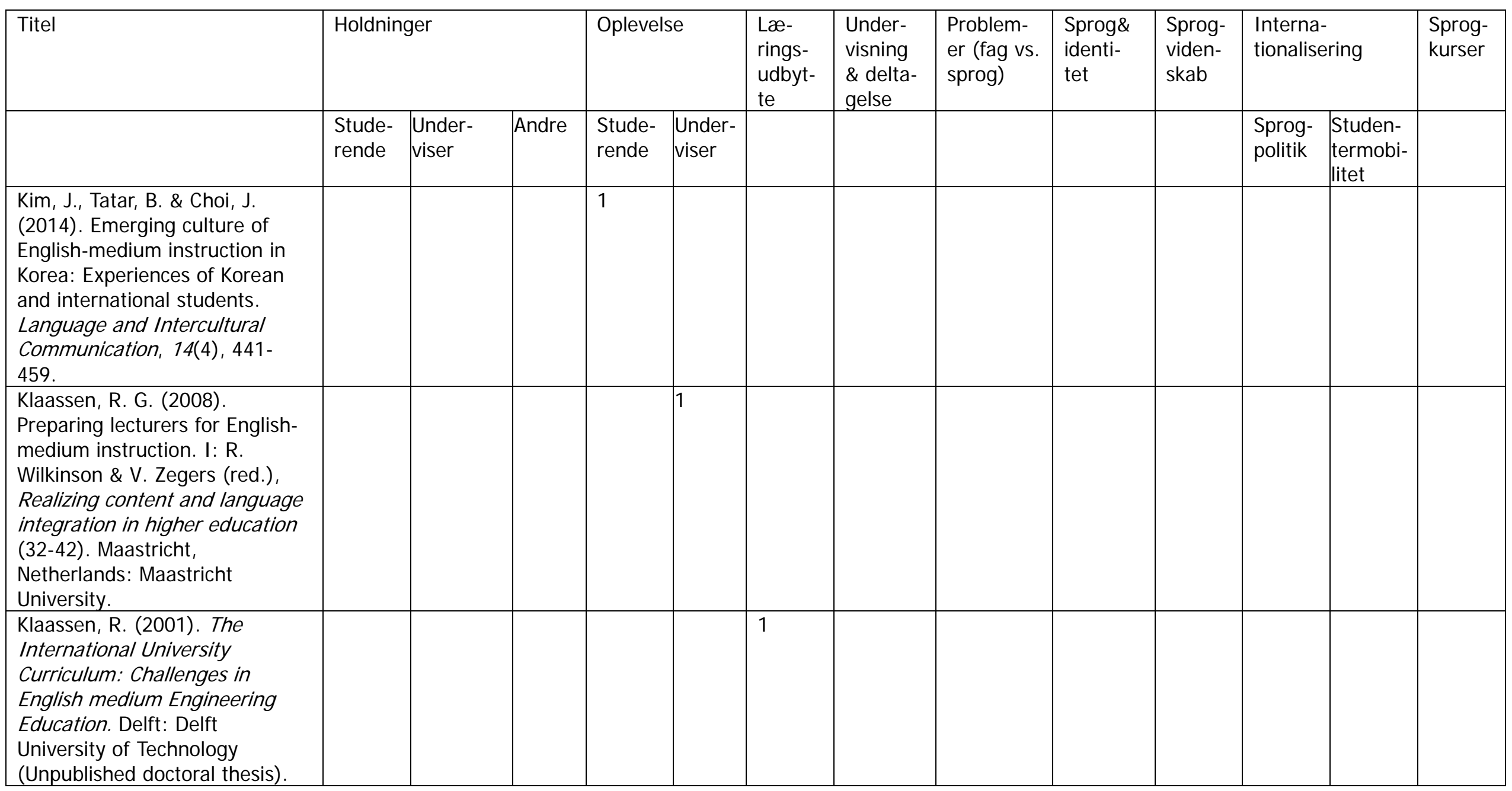




\begin{tabular}{|c|c|c|c|c|c|c|c|c|c|c|c|c|c|}
\hline \multirow[t]{2}{*}{ Titel } & \multicolumn{3}{|c|}{ Holdninger } & \multicolumn{2}{|c|}{ Oplevelse } & \multirow{2}{*}{$\begin{array}{l}\text { Læ- } \\
\text { rings- } \\
\text { udbyt- } \\
\text { te }\end{array}$} & \multirow{2}{*}{$\begin{array}{l}\text { Under- } \\
\text { visning } \\
\& \text { delta- } \\
\text { gelse }\end{array}$} & \multirow{2}{*}{$\begin{array}{l}\text { Problem- } \\
\text { er (fag vs. } \\
\text { sprog) }\end{array}$} & \multirow{2}{*}{$\begin{array}{l}\text { Sprog\& } \\
\text { identi- } \\
\text { tet }\end{array}$} & \multirow{2}{*}{$\begin{array}{l}\text { Sprog- } \\
\text { viden- } \\
\text { skab }\end{array}$} & \multicolumn{2}{|c|}{$\begin{array}{l}\text { Interna- } \\
\text { tionalisering }\end{array}$} & \multirow[t]{2}{*}{$\begin{array}{l}\text { Sprog- } \\
\text { kurser }\end{array}$} \\
\hline & $\begin{array}{l}\text { Stude- } \\
\text { rende }\end{array}$ & $\begin{array}{l}\text { Under- } \\
\text { viser }\end{array}$ & Andre & $\begin{array}{l}\text { Stude- } \\
\text { rende }\end{array}$ & $\begin{array}{l}\text { Under- } \\
\text { viser }\end{array}$ & & & & & & $\begin{array}{l}\text { Sprog- } \\
\text { politik }\end{array}$ & $\begin{array}{l}\text { Studen- } \\
\text { termobi- } \\
\text { litet }\end{array}$ & \\
\hline $\begin{array}{l}\text { Kormos, J., Csizér, K \& I waniec, } \\
\text { J. (2014). A mixed-method } \\
\text { study of language-learning } \\
\text { motivation and intercultural } \\
\text { contact of international } \\
\text { students. Journal of Multilingual } \\
\text { and Multicultural Development, } \\
35(2), 151-166 .\end{array}$ & & & & & & & & & & & & 1 & \\
\hline $\begin{array}{l}\text { Kuroda, C. (2014). The new } \\
\text { sphere of international student } \\
\text { education in Chinese higher } \\
\text { education: A focus on English- } \\
\text { medium degree programs. } \\
\text { Journal of Studies in } \\
\text { International Education, 18(5), } \\
\text { 445-462. }\end{array}$ & & & & & & & & & & & 1 & 1 & \\
\hline $\begin{array}{l}\text { Kyeyune, R. (2003). Challenges } \\
\text { of using English as a medium of } \\
\text { instruction in multilingual } \\
\text { contexts: A View from Ugandan } \\
\text { classrooms. Language, Culture } \\
\text { and Curriculum, 16(2), 173-184. }\end{array}$ & & & & & & & 1 & 1 & & & & & \\
\hline
\end{tabular}




\begin{tabular}{|c|c|c|c|c|c|c|c|c|c|c|c|c|c|}
\hline Titel & Holdnir & & & Oplevel & & $\begin{array}{l}\text { Læ- } \\
\text { rings- }\end{array}$ & $\begin{array}{l}\text { Under- } \\
\text { visning }\end{array}$ & $\begin{array}{l}\text { Problem- } \\
\text { er (fag vs. }\end{array}$ & $\begin{array}{l}\text { Sprog\& } \\
\text { identi- }\end{array}$ & $\begin{array}{l}\text { Sprog- } \\
\text { viden- }\end{array}$ & $\begin{array}{l}\text { Interna } \\
\text { tionalis }\end{array}$ & ering & $\begin{array}{l}\text { Sprog- } \\
\text { kurser }\end{array}$ \\
\hline & $\begin{array}{l}\text { Stude- } \\
\text { rende }\end{array}$ & $\begin{array}{l}\text { Under- } \\
\text { viser }\end{array}$ & Andre & $\begin{array}{l}\text { Stude- } \\
\text { rende }\end{array}$ & $\begin{array}{l}\text { Under- } \\
\text { viser }\end{array}$ & & & & & & $\begin{array}{l}\text { Sprog- } \\
\text { politik }\end{array}$ & $\begin{array}{l}\text { Studen- } \\
\text { termobi- } \\
\text { litet }\end{array}$ & \\
\hline $\begin{array}{l}\text { Lasagabaster, D., Cots, J. M. \& } \\
\text { Mancho-Barés, G. (2013). } \\
\text { Teaching staff's views about the } \\
\text { internationalisation of higher } \\
\text { education: The case of two } \\
\text { bilingual communities in Spain. } \\
\text { Multilingua: Journal of Cross- } \\
\text { Cultural and Interlanguage } \\
\text { Communication, 32(6), 751- } \\
778 \text {. }\end{array}$ & & 1 & & & & & & & & & & 1 & \\
\hline $\begin{array}{l}\text { Le Phan, H. (2013). Issues } \\
\text { surrounding English, the } \\
\text { internationalization of higher } \\
\text { education and national cultural } \\
\text { identity in Asia: A focus on } \\
\text { J apan. Critical Studies in } \\
\text { Education, 54(2), 160-175. }\end{array}$ & & & & & & & & & & & 1 & & \\
\hline $\begin{array}{l}\text { Lee, B., Farruggia, S. P. \& } \\
\text { Brown, G. T. L. (2013). } \\
\text { Academic difficulties } \\
\text { encountered by East Asian } \\
\text { international university students } \\
\text { in New Zealand. Higher } \\
\text { Education Research and } \\
\text { Development, 32(6), 915-931. }\end{array}$ & & & & & & & & 1 & & & & 1 & \\
\hline
\end{tabular}




\begin{tabular}{|c|c|c|c|c|c|c|c|c|c|c|c|c|c|}
\hline \multirow[t]{2}{*}{ Titel } & \multicolumn{3}{|c|}{ Holdninger } & \multicolumn{2}{|c|}{ Oplevelse } & \multirow{2}{*}{$\begin{array}{l}\text { Læ- } \\
\text { rings- } \\
\text { udbyt- } \\
\text { te }\end{array}$} & \multirow{2}{*}{$\begin{array}{l}\text { Under- } \\
\text { visning } \\
\text { \& delta- } \\
\text { gelse }\end{array}$} & \multirow{2}{*}{$\begin{array}{l}\text { Problem- } \\
\text { er (fag vs. } \\
\text { sprog) }\end{array}$} & \multirow{2}{*}{$\begin{array}{l}\text { Sprog\& } \\
\text { identi- } \\
\text { tet }\end{array}$} & \multirow{2}{*}{$\begin{array}{l}\text { Sprog- } \\
\text { viden- } \\
\text { skab }\end{array}$} & \multicolumn{2}{|c|}{$\begin{array}{l}\text { Interna- } \\
\text { tionalisering }\end{array}$} & \multirow[t]{2}{*}{$\begin{array}{l}\text { Sprog- } \\
\text { kurser }\end{array}$} \\
\hline & $\begin{array}{l}\text { Stude- } \\
\text { rende }\end{array}$ & $\begin{array}{l}\text { Under- } \\
\text { viser }\end{array}$ & Andre & $\begin{array}{l}\text { Stude- } \\
\text { rende }\end{array}$ & $\begin{array}{l}\text { Under- } \\
\text { viser }\end{array}$ & & & & & & $\begin{array}{l}\text { Sprog- } \\
\text { politik }\end{array}$ & \begin{tabular}{|l|} 
Studen- \\
termobi- \\
litet
\end{tabular} & \\
\hline $\begin{array}{l}\text { Lee, H. (2014). Measuring } \\
\text { cognitive load with } \\
\text { electroencephalography and } \\
\text { self-report: Focus on the effect } \\
\text { of English-medium learning for } \\
\text { Korean students. Educational } \\
\text { Psychology, 34(7), 838-848. }\end{array}$ & & & & & & 1 & & & & & & & \\
\hline $\begin{array}{l}\text { Lin, L. H. F. \& Morrison, B. } \\
\text { (2010). The impact of the } \\
\text { medium of instruction in Hong } \\
\text { Kong secondary schools on } \\
\text { tertiary students' vocabulary. } \\
\text { Journal of English for Academic } \\
\text { Purposes, } 94 \text { (4), } 255-266 .\end{array}$ & & & & & & & & 1 & & & 1 & & \\
\hline $\begin{array}{l}\text { Liu, M. \& J ackson, J. (2008). An } \\
\text { exploration of Chinese EFL } \\
\text { learners' unwillingness to } \\
\text { communicate and foreign } \\
\text { language anxiety. Modern } \\
\text { Language Journal, 92(1), 71-86. }\end{array}$ & & & & & & & 1 & 1 & & & & & \\
\hline
\end{tabular}




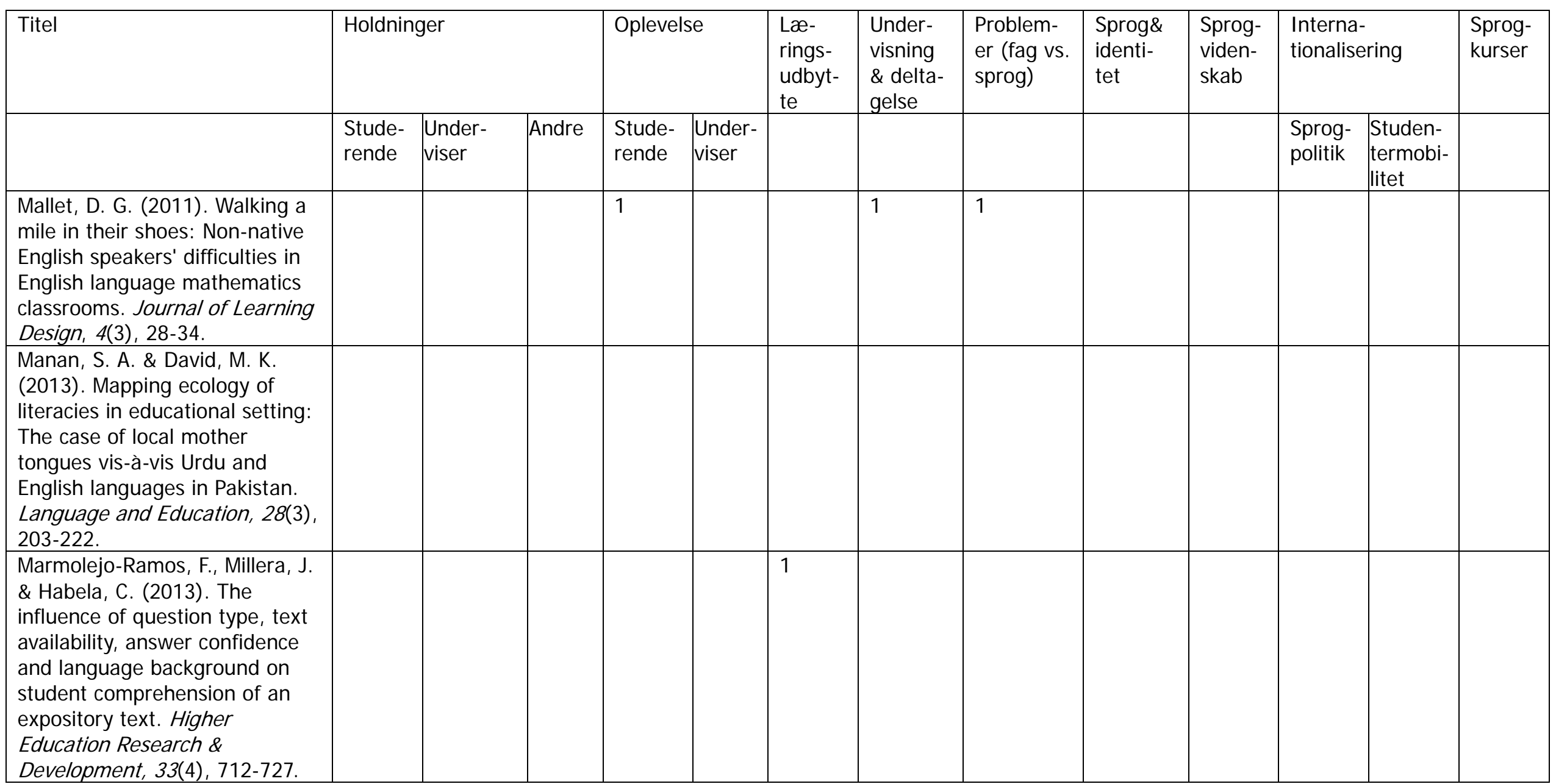




\begin{tabular}{|c|c|c|c|c|c|c|c|c|c|c|c|c|c|}
\hline Titel & \begin{tabular}{|l} 
Holdnin \\
\end{tabular} & ger & & Oplevel & & $\begin{array}{l}\text { Læ- } \\
\text { rings- }\end{array}$ & $\begin{array}{l}\text { Under- } \\
\text { visning }\end{array}$ & $\begin{array}{l}\text { Problem- } \\
\text { er (fag vs. }\end{array}$ & $\begin{array}{l}\text { Sprog\& } \\
\text { identi- }\end{array}$ & $\begin{array}{l}\text { Sprog- } \\
\text { viden- }\end{array}$ & $\begin{array}{l}\text { Interna } \\
\text { tionalis }\end{array}$ & ering & $\begin{array}{l}\text { Sprog- } \\
\text { kurser }\end{array}$ \\
\hline & \begin{tabular}{|l} 
Stude- \\
rende
\end{tabular} & $\begin{array}{l}\text { Under- } \\
\text { viser }\end{array}$ & Andre & $\begin{array}{l}\text { Stude- } \\
\text { rende }\end{array}$ & $\begin{array}{l}\text { Under- } \\
\text { viser }\end{array}$ & & & & & & $\begin{array}{l}\text { Sprog- } \\
\text { politik }\end{array}$ & $\begin{array}{l}\text { Studen- } \\
\text { termobi- } \\
\text { litet }\end{array}$ & \\
\hline $\begin{array}{l}\text { Marriott, H. (2013). } \\
\text { Multilingualism among } \\
\text { university staff: A case study of } \\
\text { language management at an } \\
\text { Australian university. } \\
\text { International Journal of } \\
\text { Multilingualism, 1a4), 454-468. }\end{array}$ & & & & & & & & & & 1 & & & \\
\hline $\begin{array}{l}\text { Martin, P. (2010). "They have } \\
\text { lost their identity but not gained } \\
\text { a British one": Non-traditional } \\
\text { multilingual students in higher } \\
\text { education in the United } \\
\text { Kingdom. Language and } \\
\text { Education, 24(1), 9-20. }\end{array}$ & & & & & & & & & 1 & & & & \\
\hline $\begin{array}{l}\text { Mathews, J. (2007). Predicting } \\
\text { international students' academic } \\
\text { success... may not always be } \\
\text { enough: Assessing Turkey's } \\
\text { foreign study scholarship } \\
\text { program. Higher Education, } \\
53(5), 645-673 \text {. }\end{array}$ & & & & & & & & 1 & & & & 1 & \\
\hline
\end{tabular}




\begin{tabular}{|c|c|c|c|c|c|c|c|c|c|c|c|c|c|}
\hline \multirow[t]{2}{*}{ Titel } & \multicolumn{3}{|c|}{ Holdninger } & \multicolumn{2}{|c|}{ Oplevelse } & \multirow{2}{*}{$\begin{array}{l}\text { Læ- } \\
\text { rings- } \\
\text { udbyt- } \\
\text { te }\end{array}$} & \multirow{2}{*}{$\begin{array}{l}\text { Under- } \\
\text { visning } \\
\& \text { delta- } \\
\text { gelse }\end{array}$} & \multirow{2}{*}{$\begin{array}{l}\text { Problem- } \\
\text { er (fag vs. } \\
\text { sprog) }\end{array}$} & \multirow{2}{*}{$\begin{array}{l}\text { Sprog\& } \\
\text { identi- } \\
\text { tet }\end{array}$} & \multirow{2}{*}{$\begin{array}{l}\text { Sprog- } \\
\text { viden- } \\
\text { skab }\end{array}$} & \multicolumn{2}{|c|}{$\begin{array}{l}\text { Interna- } \\
\text { tionalisering }\end{array}$} & \multirow[t]{2}{*}{$\begin{array}{l}\text { Sprog- } \\
\text { kurser }\end{array}$} \\
\hline & $\begin{array}{l}\text { Stude- } \\
\text { rende }\end{array}$ & $\begin{array}{l}\text { Under- } \\
\text { viser }\end{array}$ & Andre & $\begin{array}{l}\text { Stude- } \\
\text { rende }\end{array}$ & $\begin{array}{l}\text { Under- } \\
\text { viser }\end{array}$ & & & & & & $\begin{array}{l}\text { Sprog- } \\
\text { politik }\end{array}$ & $\begin{array}{l}\text { Studen- } \\
\text { termobi- } \\
\text { litet }\end{array}$ & \\
\hline $\begin{array}{l}\text { Matsuoka, R., Matsumoto, K., } \\
\text { Poole, G. \& Matsuoka, M. } \\
\text { (2014). J apanese university } \\
\text { students' willingness to } \\
\text { communicate in English: The } \\
\text { serendipitous effect of oral } \\
\text { presentations. Journal of Pan- } \\
\text { Pacific Association of Applied } \\
\text { Linguistics, 18(1), 193-218. }\end{array}$ & & & & & & & 1 & & & & & & \\
\hline $\begin{array}{l}\text { Mauranen, A., Hynninen, N. \& } \\
\text { Ranta, E. (2010): English as an } \\
\text { academic lingua franca: The } \\
\text { ELFA project. English for } \\
\text { Specific Purposes, 29(3), 183- } \\
190 .\end{array}$ & & & & 1 & 1 & & & & & 1 & & & \\
\hline $\begin{array}{l}\text { Mazak , C. M. \& Herbas- } \\
\text { Donoso, C. (2014). } \\
\text { Translanguaging practices and } \\
\text { language ideologies in Puerto } \\
\text { Rican university science } \\
\text { education. Critical Inquiry in } \\
\text { Language Studies, 11(1), 27-49. }\end{array}$ & & 1 & & & & & & & & 1 & & & \\
\hline
\end{tabular}




\begin{tabular}{|c|c|c|c|c|c|c|c|c|c|c|c|c|c|}
\hline \multirow[t]{2}{*}{ Titel } & \multicolumn{3}{|c|}{ Holdninger } & \multicolumn{2}{|c|}{ Oplevelse } & \multirow{2}{*}{$\begin{array}{l}\text { Læ- } \\
\text { rings- } \\
\text { udbyt- } \\
\text { te }\end{array}$} & \multirow{2}{*}{$\begin{array}{l}\text { Under- } \\
\text { visning } \\
\& \text { delta- } \\
\text { gelse }\end{array}$} & \multirow{2}{*}{$\begin{array}{l}\text { Problem- } \\
\text { er (fag vs. } \\
\text { sprog) }\end{array}$} & \multirow{2}{*}{$\begin{array}{l}\text { Sprog\& } \\
\text { identi- } \\
\text { tet }\end{array}$} & \multirow{2}{*}{$\begin{array}{l}\text { Sprog- } \\
\text { viden- } \\
\text { skab }\end{array}$} & \multicolumn{2}{|c|}{$\begin{array}{l}\text { Interna- } \\
\text { tionalisering }\end{array}$} & \multirow[t]{2}{*}{$\begin{array}{l}\text { Sprog- } \\
\text { kurser }\end{array}$} \\
\hline & \begin{tabular}{|l} 
Stude- \\
rende
\end{tabular} & $\begin{array}{l}\text { Under- } \\
\text { viser }\end{array}$ & Andre & $\begin{array}{l}\text { Stude- } \\
\text { rende }\end{array}$ & $\begin{array}{l}\text { Under- } \\
\text { viser }\end{array}$ & & & & & & $\begin{array}{l}\text { Sprog- } \\
\text { politik }\end{array}$ & $\begin{array}{l}\text { Studen- } \\
\text { termobi- } \\
\text { litet }\end{array}$ & \\
\hline $\begin{array}{l}\text { Miller, L. (2007). Issues in } \\
\text { lecturing in a second language: } \\
\text { Lecturer's behaviour and } \\
\text { students' perceptions, Studies in } \\
\text { Higher Education, 32(6), 747- } \\
760 .\end{array}$ & & & & & & & & 1 & & & & & \\
\hline $\begin{array}{l}\text { Morell, T. (2007). What } \\
\text { enhances EFL students' } \\
\text { participation in lecture } \\
\text { discourse? Student, lecturer and } \\
\text { discourse perspectives. Journal } \\
\text { of English for Academic } \\
\text { Purposes, } 63 \text { (3), 222-237.. }\end{array}$ & & & & & & & 1 & & & & & & \\
\hline $\begin{array}{l}\text { Murray, N. (2012). Ten "good } \\
\text { practice principles" ...Ten key } \\
\text { questions: Considerations in } \\
\text { addressing the English language } \\
\text { needs of higher education } \\
\text { students. Higher Education } \\
\text { Research and Development, } \\
\text { 31(2). 233-246. }\end{array}$ & & & & & & & & & & & & 1 & \\
\hline
\end{tabular}




\begin{tabular}{|c|c|c|c|c|c|c|c|c|c|c|c|c|c|}
\hline Titel & Holdnin & ger & & Oplevels & & $\begin{array}{l}\text { Læ- } \\
\text { rings- }\end{array}$ & $\begin{array}{l}\text { Under- } \\
\text { visning }\end{array}$ & $\begin{array}{l}\text { Problem- } \\
\text { er (fag vs. }\end{array}$ & $\begin{array}{l}\text { Sprog\& } \\
\text { identi- }\end{array}$ & $\begin{array}{l}\text { Sprog- } \\
\text { viden- }\end{array}$ & $\begin{array}{l}\text { Interna- } \\
\text { tionalise }\end{array}$ & ering & $\begin{array}{l}\text { Sprog- } \\
\text { kurser }\end{array}$ \\
\hline & $\begin{array}{l}\text { Stude- } \\
\text { rende }\end{array}$ & $\begin{array}{l}\text { Under- } \\
\text { viser }\end{array}$ & Andre & $\begin{array}{l}\text { Stude- } \\
\text { rende }\end{array}$ & $\begin{array}{l}\text { Under- } \\
\text { viser }\end{array}$ & & & & & & $\begin{array}{l}\text { Sprog- } \\
\text { politik }\end{array}$ & \begin{tabular}{|l|} 
Studen- \\
termobi- \\
litet
\end{tabular} & \\
\hline $\begin{array}{l}\text { Murray, N. (2013). Widening } \\
\text { participation and English } \\
\text { language proficiency: A } \\
\text { convergence with implications } \\
\text { for assessment practices in } \\
\text { higher education. Studies in } \\
\text { Higher Education, 38(2), 299- } \\
\text { 311. }\end{array}$ & & & & & & & & 1 & & & & & \\
\hline $\begin{array}{l}\text { Nevile-Barton, P. \& Barton, B. } \\
\text { (2005). The relationship } \\
\text { between English language and } \\
\text { mathematics learning for non- } \\
\text { native speakers. Wellington: } \\
\text { Teaching and Learning Research } \\
\text { Initiative. }\end{array}$ & & & & & & 1 & & & & & & & \\
\hline $\begin{array}{l}\text { Ngcobo, S. (2014). The struggle } \\
\text { to maintain identity in higher } \\
\text { education among Zulu-speaking } \\
\text { students. International Journal } \\
\text { of Bilingual Education and } \\
\text { Bilingualism, 176), 695-713. }\end{array}$ & & & & & & & & 1 & 1 & & & & \\
\hline $\begin{array}{l}\text { Oliver, R., Vanderford, S. \& } \\
\text { Grote, E. (2012). Evidence of } \\
\text { English language proficiency } \\
\text { and academic achievement of } \\
\text { non-English-speaking } \\
\text { background students. Higher } \\
\text { Education Research and } \\
\text { Development, 31(4), 541-555. }\end{array}$ & & & & & & & & 1 & & & & 1 & \\
\hline
\end{tabular}




\begin{tabular}{|c|c|c|c|c|c|c|c|c|c|c|c|c|c|}
\hline Titel & \begin{tabular}{|l|} 
Holdnin \\
\end{tabular} & ger & & Opleve & & $\begin{array}{l}\text { Læ- } \\
\text { rings- }\end{array}$ & $\begin{array}{l}\text { Under- } \\
\text { visning }\end{array}$ & $\begin{array}{l}\text { Problem- } \\
\text { er (fag vs. }\end{array}$ & $\begin{array}{l}\text { Sprog\& } \\
\text { identi- }\end{array}$ & $\begin{array}{l}\text { Sprog- } \\
\text { viden- }\end{array}$ & $\begin{array}{l}\text { Interna } \\
\text { tionalis }\end{array}$ & ering & $\begin{array}{l}\text { Sprog- } \\
\text { kurser }\end{array}$ \\
\hline & \begin{tabular}{|l} 
Stude- \\
rende
\end{tabular} & $\begin{array}{l}\text { Under- } \\
\text { viser }\end{array}$ & Andre & $\begin{array}{l}\text { Stude- } \\
\text { rende }\end{array}$ & $\begin{array}{l}\text { Under- } \\
\text { viser }\end{array}$ & & & & & & $\begin{array}{l}\text { Sprog- } \\
\text { politik }\end{array}$ & $\begin{array}{l}\text { Studen- } \\
\text { termobi- } \\
\text { litet }\end{array}$ & \\
\hline $\begin{array}{l}\text { Onsman, A. (2013). } \\
\text { International students at } \\
\text { Chinese joint venture } \\
\text { universities: Factors influencing } \\
\text { decisions to enrol. Australian } \\
\text { Universities' Review, } 55(2), 15- \\
23 \text {. }\end{array}$ & & & & & & & & & & & & 1 & \\
\hline $\begin{array}{l}\text { Parkinson, J. \& Crouch, A. } \\
\text { (2011). Education, language, } \\
\text { and identity amongst students } \\
\text { at a South African university. } \\
\text { Journal of Language, Identity, } \\
\text { and Education, 10(2), 83-98. }\end{array}$ & 1 & & & & & & & 1 & & & & & \\
\hline $\begin{array}{l}\text { Paxton, M. I. J. (2009). "It's } \\
\text { easy to learn when you using } \\
\text { your home language but with } \\
\text { English you need to start } \\
\text { learning language before you } \\
\text { get to the concept": Bilingual } \\
\text { concept development in an } \\
\text { English-medium university in } \\
\text { South Africa. Journal of } \\
\text { Multilingual and Multicultural } \\
\text { Development, 304), 345-359. }\end{array}$ & & & & & & 1 & & & & & & & \\
\hline
\end{tabular}




\begin{tabular}{|c|c|c|c|c|c|c|c|c|c|c|c|c|c|}
\hline Titel & Holdnin & ger & & Oplevel & & $\begin{array}{l}\text { Læ- } \\
\text { rings- }\end{array}$ & $\begin{array}{l}\text { Under- } \\
\text { visning }\end{array}$ & $\begin{array}{l}\text { Problem- } \\
\text { er (fag vs. }\end{array}$ & $\begin{array}{l}\text { Sprog\& } \\
\text { identi- }\end{array}$ & $\begin{array}{l}\text { Sprog- } \\
\text { viden- }\end{array}$ & $\begin{array}{l}\text { Interna } \\
\text { tionalis }\end{array}$ & ering & $\begin{array}{l}\text { Sprog- } \\
\text { kurser }\end{array}$ \\
\hline & \begin{tabular}{|l|} 
Stude- \\
rende
\end{tabular} & $\begin{array}{l}\text { Under- } \\
\text { viser }\end{array}$ & Andre & $\begin{array}{l}\text { Stude- } \\
\text { rende }\end{array}$ & $\begin{array}{l}\text { Under- } \\
\text { viser }\end{array}$ & & & & & & $\begin{array}{l}\text { Sprog- } \\
\text { politik }\end{array}$ & $\begin{array}{l}\text { Studen- } \\
\text { termobi- } \\
\text { litet }\end{array}$ & \\
\hline $\begin{array}{l}\text { Preece, S. (2010). Multilingual } \\
\text { identities in higher education: } \\
\text { Negotiating the "mother } \\
\text { tongue", "posh" and "slang". } \\
\text { Language and Education, 24(1), } \\
\text { 21-39. }\end{array}$ & & & & & & & & & 1 & & & & \\
\hline $\begin{array}{l}\text { Pretorius, E. J. (2006). The } \\
\text { comprehension of logical } \\
\text { relations in expository texts by } \\
\text { students who study through the } \\
\text { medium of ESL. System: An } \\
\text { International Journal of } \\
\text { Educational Technology and } \\
\text { Applied Linguistics, 34(3), 432- } \\
450 .\end{array}$ & & & & & & 1 & & 1 & & & & & \\
\hline $\begin{array}{l}\text { Ramburuth, P. (2001). } \\
\text { Language diversity and the first- } \\
\text { year experience: Implications } \\
\text { for academic achievement and } \\
\text { language skills acquisition. } \\
\text { Journal of the First-Year } \\
\text { Experience \& Students in } \\
\text { Transition, 13(2),75-94.. }\end{array}$ & & & & & & 1 & & 1 & & & & & \\
\hline
\end{tabular}




\begin{tabular}{|c|c|c|c|c|c|c|c|c|c|c|c|c|c|}
\hline Titel & Holdnir & & & Oplevel & & $\begin{array}{l}\text { Læ- } \\
\text { rings- }\end{array}$ & $\begin{array}{l}\text { Under- } \\
\text { visning }\end{array}$ & $\begin{array}{l}\text { Problem- } \\
\text { er (fag vs. }\end{array}$ & $\begin{array}{l}\text { Sprog\& } \\
\text { identi- }\end{array}$ & $\begin{array}{l}\text { Sprog- } \\
\text { viden- }\end{array}$ & $\begin{array}{l}\text { Interna } \\
\text { tionalis }\end{array}$ & ering & $\begin{array}{l}\text { Sprog- } \\
\text { kurser }\end{array}$ \\
\hline & $\begin{array}{l}\text { Stude- } \\
\text { rende }\end{array}$ & $\begin{array}{l}\text { Under- } \\
\text { viser }\end{array}$ & Andre & $\begin{array}{l}\text { Stude- } \\
\text { rende }\end{array}$ & $\begin{array}{l}\text { Under- } \\
\text { viser }\end{array}$ & & & & & & $\begin{array}{l}\text { Sprog- } \\
\text { politik }\end{array}$ & \begin{tabular}{|l|} 
Studen- \\
termobi- \\
litet
\end{tabular} & \\
\hline $\begin{array}{l}\text { Ramsay, S., Barker, M. \&J ones, } \\
\text { E. (1999): Academic adjustment } \\
\text { and learning processes: A } \\
\text { comparison of international and } \\
\text { local students in first-year } \\
\text { university. Higher Education } \\
\text { Research \& Development 1\&1), } \\
\text { 129-144. }\end{array}$ & & & & 1 & & & & & & & & & \\
\hline $\begin{array}{l}\text { Rees, J. \& Klapper, J. (2007). } \\
\text { Analysing and evaluating the } \\
\text { linguistic benefit of residence } \\
\text { abroad for UK foreign language } \\
\text { students. Assesment \& } \\
\text { Evaluation in Higher Education } \\
\text { 32(3), 331-353. }\end{array}$ & & & & & & & & & & & & 1 & \\
\hline $\begin{array}{l}\text { Rienties, B., Luchoomun, D. \& } \\
\text { Tempelaar, D. (2014). Academic } \\
\text { and social integration of master } \\
\text { students: A cross-institutional } \\
\text { comparison between Dutch and } \\
\text { international students. } \\
\text { Innovations in Education and } \\
\text { Teaching International, 51(2), } \\
\text { 130-141. }\end{array}$ & & & & & & 1 & & & & & & 1 & \\
\hline
\end{tabular}




\begin{tabular}{|c|c|c|c|c|c|c|c|c|c|c|c|c|c|}
\hline \multirow[t]{2}{*}{ Titel } & \multicolumn{3}{|c|}{ Holdninger } & \multicolumn{2}{|c|}{ Oplevelse } & \multirow{2}{*}{$\begin{array}{l}\text { Læ- } \\
\text { rings- } \\
\text { udbyt- } \\
\text { te }\end{array}$} & \multirow{2}{*}{$\begin{array}{l}\text { Under- } \\
\text { visning } \\
\& \text { delta- } \\
\text { gelse }\end{array}$} & \multirow{2}{*}{$\begin{array}{l}\text { Problem- } \\
\text { er (fag vs. } \\
\text { sprog) }\end{array}$} & \multirow{2}{*}{$\begin{array}{l}\text { Sprog\& } \\
\text { identi- } \\
\text { tet }\end{array}$} & \multirow{2}{*}{$\begin{array}{l}\text { Sprog- } \\
\text { viden- } \\
\text { skab }\end{array}$} & \multicolumn{2}{|c|}{$\begin{array}{l}\text { Interna- } \\
\text { tionalisering }\end{array}$} & \multirow[t]{2}{*}{$\begin{array}{l}\text { Sprog- } \\
\text { kurser }\end{array}$} \\
\hline & $\begin{array}{l}\text { Stude- } \\
\text { rende }\end{array}$ & $\begin{array}{l}\text { Under- } \\
\text { viser }\end{array}$ & Andre & $\begin{array}{l}\text { Stude- } \\
\text { rende }\end{array}$ & $\begin{array}{l}\text { Under- } \\
\text { viser }\end{array}$ & & & & & & $\begin{array}{l}\text { Sprog- } \\
\text { politik }\end{array}$ & $\begin{array}{l}\text { Studen- } \\
\text { termobi- } \\
\text { litet }\end{array}$ & \\
\hline $\begin{array}{l}\text { Saarinen, T. (2012). } \\
\text { Internationalization of Finnish } \\
\text { higher education - is language } \\
\text { an issue? International Journal } \\
\text { of the Sociology of Language, } \\
216,157-173 \text {. }\end{array}$ & & & & & & & & & & & 1 & & \\
\hline $\begin{array}{l}\text { Sakurai, Y. (2009). Academic } \\
\text { experiences in a cross-national } \\
\text { tertiary program: Language } \\
\text { immersion amid the sciences. } \\
\text { International Journal of } \\
\text { Teaching and Learning in Higher } \\
\text { Education, 21(2), 239-248. }\end{array}$ & & & & 1 & & & & 1 & & & & 1 & \\
\hline
\end{tabular}




\begin{tabular}{|c|c|c|c|c|c|c|c|c|c|c|c|c|c|}
\hline Titel & \begin{tabular}{|l} 
Holdnin \\
\end{tabular} & gger & & Oplevel & & $\begin{array}{l}\text { Læ- } \\
\text { rings- }\end{array}$ & $\begin{array}{l}\text { Under- } \\
\text { visning }\end{array}$ & $\begin{array}{l}\text { Problem- } \\
\text { er (fag vs. }\end{array}$ & $\begin{array}{l}\text { Sprog\& } \\
\text { identi- }\end{array}$ & $\begin{array}{l}\text { Sprog- } \\
\text { viden- }\end{array}$ & $\begin{array}{l}\text { Interna } \\
\text { tionalis }\end{array}$ & ering & $\begin{array}{l}\text { Sprog- } \\
\text { kurser }\end{array}$ \\
\hline & $\begin{array}{l}\text { Stude- } \\
\text { rende }\end{array}$ & $\begin{array}{l}\text { Under- } \\
\text { viser }\end{array}$ & Andre & $\begin{array}{l}\text { Stude- } \\
\text { rende }\end{array}$ & $\begin{array}{l}\text { Under- } \\
\text { viser }\end{array}$ & & & & & & $\begin{array}{l}\text { Sprog- } \\
\text { politik }\end{array}$ & \begin{tabular}{|l} 
Studen- \\
termobi- \\
litet
\end{tabular} & \\
\hline $\begin{array}{l}\text { Sasayama, S. (2013). Japanese } \\
\text { college students' attitudes } \\
\text { towards J apan English and } \\
\text { American English. Journal of } \\
\text { Multilingual and Multicultural } \\
\text { Development, 34(3), 264-278. }\end{array}$ & 1 & & & & & & & & & & & & \\
\hline $\begin{array}{l}\text { Schoerning, E. (2014). The } \\
\text { effect of plain-English } \\
\text { vocabulary on student } \\
\text { achievement and classroom } \\
\text { culture in college science } \\
\text { instruction. International } \\
\text { Journal of Science and } \\
\text { Mathematics Education, 12(2), } \\
\text { 307-327. }\end{array}$ & & & & & & 1 & & & & & & & 1 \\
\hline $\begin{array}{l}\text { Skyrme, G. (2007). Entering the } \\
\text { university: the differentiated } \\
\text { experience of two Chinese } \\
\text { international students in a New } \\
\text { Zealand university. Studies in } \\
\text { Higher Education, 32(3), 357- } \\
\text { 372. }\end{array}$ & & & & 1 & & & & & & & & 1 & \\
\hline
\end{tabular}




\begin{tabular}{|c|c|c|c|c|c|c|c|c|c|c|c|c|c|}
\hline \multirow[t]{2}{*}{ Titel } & \multicolumn{3}{|c|}{ Holdninger } & \multicolumn{2}{|c|}{ Oplevelse } & \multirow{2}{*}{$\begin{array}{l}\text { Læ- } \\
\text { rings- } \\
\text { udbyt- } \\
\text { te }\end{array}$} & \multirow{2}{*}{$\begin{array}{l}\text { Under- } \\
\text { visning } \\
\& \text { delta- } \\
\text { gelse }\end{array}$} & \multirow{2}{*}{$\begin{array}{l}\text { Problem- } \\
\text { er (fag vs. } \\
\text { sprog) }\end{array}$} & \multirow{2}{*}{$\begin{array}{l}\text { Sprog\& } \\
\text { identi- } \\
\text { tet }\end{array}$} & \multirow{2}{*}{$\begin{array}{l}\text { Sprog- } \\
\text { viden- } \\
\text { skab }\end{array}$} & \multicolumn{2}{|c|}{$\begin{array}{l}\text { Interna- } \\
\text { tionalisering }\end{array}$} & \multirow[t]{2}{*}{$\begin{array}{l}\text { Sprog- } \\
\text { kurser }\end{array}$} \\
\hline & $\begin{array}{l}\text { Stude- } \\
\text { rende }\end{array}$ & $\begin{array}{l}\text { Under- } \\
\text { viser }\end{array}$ & Andre & $\begin{array}{l}\text { Stude- } \\
\text { rende }\end{array}$ & $\begin{array}{l}\text { Under- } \\
\text { viser }\end{array}$ & & & & & & $\begin{array}{l}\text { Sprog- } \\
\text { politik }\end{array}$ & $\begin{array}{l}\text { Studen- } \\
\text { termobi- } \\
\text { litet }\end{array}$ & \\
\hline $\begin{array}{l}\text { Soontiens, W. (2004). When in } \\
\text { Rome: The realities of skill } \\
\text { development in an "anglo" } \\
\text { educational environment. } \\
\text { Journal of Research in } \\
\text { International Education, 3(3), } \\
\text { 301-317. }\end{array}$ & & & & & & & & & & & & 1 & \\
\hline $\begin{array}{l}\text { Starfield, S. (2001). "I'm a } \\
\text { second-Language English } \\
\text { speaker": Negotiating writer } \\
\text { identity and authority in } \\
\text { sociology one. Journal of } \\
\text { Language, Identity and } \\
\text { Education 1(2), 121-140. }\end{array}$ & & & & & & & & & 1 & & & & \\
\hline $\begin{array}{l}\text { Sterzuk, A. (2015). "The } \\
\text { standard remains the same": } \\
\text { Language standardization, race } \\
\text { and othering in higher } \\
\text { education. Journal of } \\
\text { Multilingual and Multicultural } \\
\text { Development, 361), 53-66. }\end{array}$ & & 1 & & & & & & & & & 1 & & \\
\hline
\end{tabular}




\begin{tabular}{|c|c|c|c|c|c|c|c|c|c|c|c|c|c|}
\hline \multirow[t]{2}{*}{ Titel } & \multicolumn{3}{|c|}{ Holdninger } & \multicolumn{2}{|c|}{ Oplevelse } & \multirow{2}{*}{$\begin{array}{l}\text { Læ- } \\
\text { rings- } \\
\text { udbyt- } \\
\text { te }\end{array}$} & \multirow{2}{*}{$\begin{array}{l}\text { Under- } \\
\text { visning } \\
\& \text { delta- } \\
\text { gelse } \\
\end{array}$} & \multirow{2}{*}{$\begin{array}{l}\text { Problem- } \\
\text { er (fag vs. } \\
\text { sprog) }\end{array}$} & \multirow{2}{*}{$\begin{array}{l}\text { Sprog\& } \\
\text { identi- } \\
\text { tet }\end{array}$} & \multirow{2}{*}{$\begin{array}{l}\text { Sprog- } \\
\text { viden- } \\
\text { skab }\end{array}$} & \multicolumn{2}{|c|}{$\begin{array}{l}\text { Interna- } \\
\text { tionalisering }\end{array}$} & \multirow[t]{2}{*}{$\begin{array}{l}\text { Sprog- } \\
\text { kurser }\end{array}$} \\
\hline & $\begin{array}{l}\text { Stude- } \\
\text { rende }\end{array}$ & $\begin{array}{l}\text { Under- } \\
\text { viser }\end{array}$ & Andre & $\begin{array}{l}\text { Stude- } \\
\text { rende }\end{array}$ & $\begin{array}{l}\text { Under- } \\
\text { viser }\end{array}$ & & & & & & $\begin{array}{l}\text { Sprog- } \\
\text { politik }\end{array}$ & $\begin{array}{l}\text { Studen- } \\
\text { termobi- } \\
\text { litet }\end{array}$ & \\
\hline $\begin{array}{l}\text { Stoynoff, S. (1997). Factors } \\
\text { associated with international } \\
\text { students' academic } \\
\text { achievement. Journal of } \\
\text { Instructional Psychology, 24(1), } \\
\text { 56-68. }\end{array}$ & & & & & & 1 & & & & & & 1 & \\
\hline $\begin{array}{l}\text { Summers, M. \& Voleta, S. } \\
\text { (2008). Students' attitudes } \\
\text { towards culturally mixed groups } \\
\text { on international campuses: } \\
\text { impact of participation in } \\
\text { diverse and non-diverse groups. } \\
\text { Studies in Higher Education, } \\
\text { 33(4), 357-370. }\end{array}$ & 1 & & & 1 & & & & & & & & 1 & \\
\hline $\begin{array}{l}\text { Tarnopolsky, O. B. \& Goodman, } \\
\text { B. A. (2014). The ecology of } \\
\text { language in classrooms at a } \\
\text { university in eastern Ukraine. } \\
\text { Language and Education, 28(4), } \\
\text { 383-396. }\end{array}$ & 1 & 1 & & & & & & & & & & & \\
\hline
\end{tabular}




\begin{tabular}{|c|c|c|c|c|c|c|c|c|c|c|c|c|c|}
\hline \multirow[t]{2}{*}{ Titel } & \multicolumn{3}{|c|}{ Holdninger } & \multicolumn{2}{|c|}{ Oplevelse } & \multirow{2}{*}{$\begin{array}{l}\text { Læ- } \\
\text { rings- } \\
\text { udbyt- } \\
\text { te }\end{array}$} & \multirow{2}{*}{$\begin{array}{l}\text { Under- } \\
\text { visning } \\
\& \text { delta- } \\
\text { gelse }\end{array}$} & \multirow{2}{*}{$\begin{array}{l}\text { Problem- } \\
\text { er (fag vs. } \\
\text { sprog) }\end{array}$} & \multirow{2}{*}{$\begin{array}{l}\text { Sprog\& } \\
\text { identi- } \\
\text { tet }\end{array}$} & \multirow{2}{*}{$\begin{array}{l}\text { Sprog- } \\
\text { viden- } \\
\text { skab }\end{array}$} & \multicolumn{2}{|c|}{$\begin{array}{l}\text { Interna- } \\
\text { tionalisering }\end{array}$} & \multirow[t]{2}{*}{$\begin{array}{l}\text { Sprog- } \\
\text { kurser }\end{array}$} \\
\hline & $\begin{array}{l}\text { Stude- } \\
\text { rende }\end{array}$ & $\begin{array}{l}\text { Under- } \\
\text { viser }\end{array}$ & Andre & $\begin{array}{l}\text { Stude- } \\
\text { rende }\end{array}$ & $\begin{array}{l}\text { Under- } \\
\text { viser }\end{array}$ & & & & & & $\begin{array}{l}\text { Sprog- } \\
\text { politik }\end{array}$ & $\begin{array}{l}\text { Studen- } \\
\text { termobi- } \\
\text { litet }\end{array}$ & \\
\hline $\begin{array}{l}\text { Tatzl, D. (2011). English- } \\
\text { medium masters' programmes } \\
\text { at an Austrian university of } \\
\text { applied sciences: Attitudes, } \\
\text { experiences and challenges. } \\
\text { Journal of English for Academic } \\
\text { Purposes, 1a4), 252-270. }\end{array}$ & 1 & 1 & 1 & 1 & 1 & & & & & & & & \\
\hline $\begin{array}{l}\text { Toh, G. (2013). Where realities } \\
\text { confront ideals: The personal, } \\
\text { professional, philosophical and } \\
\text { political in the teaching of } \\
\text { academic English in a Japanese } \\
\text { setting. Policy Futures in } \\
\text { Education, 11(5), 589-605. }\end{array}$ & & & 1 & & & & & & & & 1 & & \\
\hline $\begin{array}{l}\text { Tong, F. \& Shi, Q. (2012). } \\
\text { Chinese-English bilingual } \\
\text { education in China: A case } \\
\text { study of college science majors. } \\
\text { International Journal of } \\
\text { Bilingual Education and } \\
\text { Bilingualism, 15(2), 165-182. }\end{array}$ & 1 & & & & & & & & & & & & \\
\hline
\end{tabular}




\begin{tabular}{|c|c|c|c|c|c|c|c|c|c|c|c|c|c|}
\hline \multirow[t]{2}{*}{ Titel } & \multicolumn{3}{|c|}{ Holdninger } & \multicolumn{2}{|c|}{ Oplevelse } & \multirow{2}{*}{$\begin{array}{l}\text { Læ- } \\
\text { rings- } \\
\text { udbyt- } \\
\text { te }\end{array}$} & \multirow{2}{*}{$\begin{array}{l}\text { Under- } \\
\text { visning } \\
\& \text { delta- } \\
\text { gelse }\end{array}$} & \multirow{2}{*}{$\begin{array}{l}\text { Problem- } \\
\text { er (fag vs. } \\
\text { sprog) }\end{array}$} & \multirow{2}{*}{$\begin{array}{l}\text { Sprog\& } \\
\text { identi- } \\
\text { tet }\end{array}$} & \multirow{2}{*}{$\begin{array}{l}\text { Sprog- } \\
\text { viden- } \\
\text { skab }\end{array}$} & \multicolumn{2}{|c|}{$\begin{array}{l}\text { Interna- } \\
\text { tionalisering }\end{array}$} & \multirow[t]{2}{*}{$\begin{array}{l}\text { Sprog- } \\
\text { kurser }\end{array}$} \\
\hline & $\begin{array}{l}\text { Stude- } \\
\text { rende }\end{array}$ & $\begin{array}{l}\text { Under- } \\
\text { viser }\end{array}$ & Andre & $\begin{array}{l}\text { Stude- } \\
\text { rende }\end{array}$ & $\begin{array}{l}\text { Under- } \\
\text { viser }\end{array}$ & & & & & & $\begin{array}{l}\text { Sprog- } \\
\text { politik }\end{array}$ & \begin{tabular}{|l|} 
Studen- \\
termobi- \\
litet
\end{tabular} & \\
\hline $\begin{array}{l}\text { Torres-Olave, B. M. (2012). } \\
\text { Imaginative geographies: } \\
\text { Identity, difference, and English } \\
\text { as the language of instruction in } \\
\text { a Mexican university program. } \\
\text { Higher Education: The } \\
\text { International Journal of Higher } \\
\text { Education and Educational } \\
\text { Planning, } 63(3), 317-335 .\end{array}$ & & & & & & & & & 1 & & & & \\
\hline $\begin{array}{l}\text { Trent, J. (2012). The } \\
\text { internationalization of tertiary } \\
\text { education in Asia: Language, } \\
\text { identity, and conflict. Journal of } \\
\text { Research in International } \\
\text { Education, 11(1), 50-69. }\end{array}$ & & & & & & & & & 1 & & & & \\
\hline $\begin{array}{l}\text { Unterberger, B. (2012). English- } \\
\text { medium programmes at } \\
\text { Austrian business faculties: A } \\
\text { status quo survey on national } \\
\text { trends and a case study on } \\
\text { programme design and delivery. } \\
\text { A/LA Review, } 25,80-100 \text {. }\end{array}$ & & & & & & & & & & & 1 & & \\
\hline
\end{tabular}




\begin{tabular}{|c|c|c|c|c|c|c|c|c|c|c|c|c|c|}
\hline Titel & Holdnir & & & Opleve & & $\begin{array}{l}\text { Læ- } \\
\text { rings- }\end{array}$ & $\begin{array}{l}\text { Under- } \\
\text { visning }\end{array}$ & $\begin{array}{l}\text { Problem- } \\
\text { er (fag vs. }\end{array}$ & $\begin{array}{l}\text { Sprog\& } \\
\text { identi- }\end{array}$ & $\begin{array}{l}\text { Sprog- } \\
\text { viden- }\end{array}$ & $\begin{array}{l}\text { Interna } \\
\text { tionalis }\end{array}$ & ering & $\begin{array}{l}\text { Sprog- } \\
\text { kurser }\end{array}$ \\
\hline & $\begin{array}{l}\text { Stude- } \\
\text { rende }\end{array}$ & $\begin{array}{l}\text { Under- } \\
\text { viser }\end{array}$ & Andre & $\begin{array}{l}\text { Stude- } \\
\text { rende }\end{array}$ & $\begin{array}{l}\text { Under- } \\
\text { viser }\end{array}$ & & & & & & $\begin{array}{l}\text { Sprog- } \\
\text { politik }\end{array}$ & \begin{tabular}{|l|} 
Studen- \\
termobi- \\
litet
\end{tabular} & \\
\hline $\begin{array}{l}\text { Vinther, J. \& Slethaug, G. } \\
\text { (2015). The impact of } \\
\text { international students on the } \\
\text { university work environment: A } \\
\text { Comparative study of a } \\
\text { Canadian and a Danish } \\
\text { university. Language and } \\
\text { Intercultural Communication, } \\
\text { 15(1), 92-108. }\end{array}$ & & & & & 1 & & & & & & & 1 & \\
\hline $\begin{array}{l}\text { Watkins, D., Biggs, J. \& Regmi, } \\
\text { M. (1991). Does confidence in } \\
\text { the medium of instruction } \\
\text { influence a student's approach } \\
\text { to learning? Instructional } \\
\text { Science, 2a4), 331-339. }\end{array}$ & & & & & & & 1 & & & & & & \\
\hline $\begin{array}{l}\text { Wilkins, S. \& Urbanovic, J. } \\
\text { (2014). English as the lingua } \\
\text { franca in transnational higher } \\
\text { education: Motives and } \\
\text { prospects of institutions that } \\
\text { teach in languages other than } \\
\text { English. Journal of Studies in } \\
\text { International Education, 18(5), } \\
\text { 405-425. }\end{array}$ & & & & & & & & & & 1 & & & \\
\hline
\end{tabular}




\begin{tabular}{|c|c|c|c|c|c|c|c|c|c|c|c|c|c|}
\hline Titel & Holdning & & & Oplevel & & $\begin{array}{l}\text { Læ- } \\
\text { rings- }\end{array}$ & $\begin{array}{l}\text { Under- } \\
\text { visning }\end{array}$ & $\begin{array}{l}\text { Problem- } \\
\text { er (fag vs. }\end{array}$ & $\begin{array}{l}\text { Sprog\& } \\
\text { identi- }\end{array}$ & $\begin{array}{l}\text { Sprog- } \\
\text { viden- }\end{array}$ & $\begin{array}{l}\text { Interna } \\
\text { tionalis }\end{array}$ & ering & $\begin{array}{l}\text { Sprog- } \\
\text { kurser }\end{array}$ \\
\hline & $\begin{array}{l}\text { Stude- } \\
\text { rende }\end{array}$ & $\begin{array}{l}\text { Under- } \\
\text { viser }\end{array}$ & Andre & $\begin{array}{l}\text { Stude- } \\
\text { rende }\end{array}$ & $\begin{array}{l}\text { Under- } \\
\text { viser }\end{array}$ & & & & & & $\begin{array}{l}\text { Sprog- } \\
\text { politik }\end{array}$ & $\begin{array}{l}\text { Studen- } \\
\text { termobi- } \\
\text { litet }\end{array}$ & \\
\hline $\begin{array}{l}\text { Yang, W. \& Gosling, M. (2014). } \\
\text { What makes a Taiwan CLIL } \\
\text { programme highly } \\
\text { recommended or not } \\
\text { recommended? International } \\
\text { Journal of Bilingual Education } \\
\text { and Bilingualism, 1オ4), 394- } \\
409 .\end{array}$ & 1 & & & 1 & & & 1 & & & & 1 & & \\
\hline $\begin{array}{l}\text { Yanyin, Z. \& Yinan, M. (2010). } \\
\text { Another look at the language } \\
\text { difficulties of international } \\
\text { students. Journal of Studies in } \\
\text { International Education, 14(4), } \\
\text { 371-388. }\end{array}$ & & & & & & & & 1 & & & & 1 & \\
\hline $\begin{array}{l}\text { Yates, L. \& Wahid, R. (2013). } \\
\text { Challenges to brand Australia: } \\
\text { International students and the } \\
\text { problem with speaking. Higher } \\
\text { Education Research and } \\
\text { Development, 32(6), 1037- } \\
\text { 1050. }\end{array}$ & & & & & & & & 1 & & & & 1 & \\
\hline
\end{tabular}




\begin{tabular}{|c|c|c|c|c|c|c|c|c|c|c|c|c|c|}
\hline Titel & Holdnin & & & Oplevel & & $\begin{array}{l}\text { Læ- } \\
\text { rings- }\end{array}$ & $\begin{array}{l}\text { Under- } \\
\text { visning }\end{array}$ & $\begin{array}{l}\text { Problem- } \\
\text { er (fag vs. }\end{array}$ & $\begin{array}{l}\text { Sprog\& } \\
\text { identi- }\end{array}$ & $\begin{array}{l}\text { Sprog- } \\
\text { viden- }\end{array}$ & $\begin{array}{l}\text { Interna } \\
\text { tionalis }\end{array}$ & ering & $\begin{array}{l}\text { Sprog- } \\
\text { kurser }\end{array}$ \\
\hline & $\begin{array}{l}\text { Stude- } \\
\text { rende }\end{array}$ & $\begin{array}{l}\text { Under- } \\
\text { viser }\end{array}$ & Andre & $\begin{array}{l}\text { Stude- } \\
\text { rende }\end{array}$ & $\begin{array}{l}\text { Under- } \\
\text { viser }\end{array}$ & & & & & & $\begin{array}{l}\text { Sprog- } \\
\text { politik }\end{array}$ & $\begin{array}{l}\text { Studen- } \\
\text { termobi- } \\
\text { litet }\end{array}$ & \\
\hline $\begin{array}{l}\text { Yeh, C.-C. (2014). Taiwanese } \\
\text { students' experiences and } \\
\text { attitudes towards English- } \\
\text { medium courses in tertiary } \\
\text { education. RELC J Journal: A } \\
\text { Journal of Language Teaching } \\
\text { and Research, 45(3), 305-319. }\end{array}$ & 1 & & & 1 & & & & & & & & & \\
\hline $\begin{array}{l}\text { Yushau, B. (2009). Mathematics } \\
\text { and language: Issues among } \\
\text { bilingual Arabs in English } \\
\text { medium universities. } \\
\text { International Journal of } \\
\text { Mathematical Education in } \\
\text { Science and Technology, 4a7), } \\
\text { 915-926. }\end{array}$ & & & & & & & 1 & & & & & & \\
\hline $\begin{array}{l}\text { Zacharias, N. T. (2013). } \\
\text { Navigating through the English- } \\
\text { medium-of-instruction policy: } \\
\text { Voices from the field. Current } \\
\text { Issues in Language Planning, } \\
\text { 14(1), 93-108. }\end{array}$ & 1 & 1 & & & & & & & & & 1 & & \\
\hline
\end{tabular}




\begin{tabular}{|c|c|c|c|c|c|c|c|c|c|c|c|c|c|}
\hline \multirow[t]{2}{*}{ Titel } & \multicolumn{3}{|c|}{ Holdninger } & \multicolumn{2}{|c|}{ Oplevelse } & \multirow{2}{*}{$\begin{array}{l}\text { Læ- } \\
\text { rings- } \\
\text { udbyt- } \\
\text { te }\end{array}$} & \multirow{2}{*}{$\begin{array}{l}\text { Under- } \\
\text { visning } \\
\& \text { delta- } \\
\text { gelse }\end{array}$} & \multirow{2}{*}{$\begin{array}{l}\text { Problem- } \\
\text { er (fag vs. } \\
\text { sprog) }\end{array}$} & \multirow{2}{*}{$\begin{array}{l}\text { Sprog\& } \\
\text { identi- } \\
\text { tet }\end{array}$} & \multirow{2}{*}{$\begin{array}{l}\text { Sprog- } \\
\text { viden- } \\
\text { skab }\end{array}$} & \multicolumn{2}{|c|}{$\begin{array}{l}\text { Interna- } \\
\text { tionalisering }\end{array}$} & \multirow[t]{2}{*}{$\begin{array}{l}\text { Sprog- } \\
\text { kurser }\end{array}$} \\
\hline & $\begin{array}{l}\text { Stude- } \\
\text { rende }\end{array}$ & $\begin{array}{l}\text { Under- } \\
\text { viser }\end{array}$ & Andre & $\begin{array}{l}\text { Stude- } \\
\text { rende }\end{array}$ & $\begin{array}{l}\text { Under- } \\
\text { viser }\end{array}$ & & & & & & $\begin{array}{l}\text { Sprog- } \\
\text { politik }\end{array}$ & $\begin{array}{l}\text { Studen- } \\
\text { termobi- } \\
\text { litet }\end{array}$ & \\
\hline $\begin{array}{l}\text { Zhao,C.-M. , Kuh, G. \& Carini, R. } \\
\text { M. (2005). A comparison of } \\
\text { international student } \\
\text { engagement and American } \\
\text { student engagement in effective } \\
\text { educational practices. Journal of } \\
\text { Higher Education, 76(2), 209- } \\
231 \text {. }\end{array}$ & & & & 1 & & & 1 & & & & & 1 & \\
\hline $\begin{array}{l}\text { Zhao, M. \& Wildemeersch, D. } \\
\text { (2008). Hosting foreign } \\
\text { students in European } \\
\text { universities: International and } \\
\text { intercultural perspectives. } \\
\text { European Education, } 4 \alpha 1 \text { ), 51- } \\
62 .\end{array}$ & & & & & & & & & & & & 1 & \\
\hline
\end{tabular}

